FRANCISCO BENNATI MADUREIRA

\title{
Cidadão-fonte ou cidadão-repórter? $O$ engajamento do público no jornalismo colaborativo dos grandes portais brasileiros
}


FRANCISCO BENNATI MADUREIRA

\title{
Cidadão-fonte ou cidadão-repórter? 0 engajamento do público no jornalismo colaborativo dos grandes portais brasileiros
}

\begin{abstract}
Dissertação apresentada ao Programa de Pós-Graduação em Ciências da Comunicação, Área de Concentração Interfaces Sociais da Comunicação, Linha de Pesquisa Tecnologias da Comunicação e Redes Interativas, da Escola de Comunicações e Artes da Universidade de São Paulo, como exigência parcial para obtenção do Título de Mestre em Ciências da Comunicação, sob a orientação da Profa. Dra. Elizabeth Saad Corrêa.
\end{abstract}


Ficha Catalográfica

Serviço de Biblioteca e Documentação da ECA/USP

MADUREIRA, Francisco B.

Cidadão-fonte ou cidadão-repórter? O engajamento do público no jornalismo colaborativo dos grandes portais brasileiros. São Paulo, 2010.

$154 \mathrm{p}$.

Dissertação (Mestrado) - Departamento de Jornalismo e Editoração/Escola de Comunicações e Artes/USP.

Orientadora: Profa. Dra. Elizabeth Saad Corrêa

Bibliografia

1. Jornalismo online 2. Notícias 3. Jornalismo colaborativo 4. Internet I. Corrêa, Elizabeth Nicolau Saad II. Título.

CDD 21.ed. - 070 


\section{TERMOS DE APROVAÇÃO}

Nome do autor: MADUREIRA, Francisco B.

Título da Dissertação: "Cidadão-fonte ou cidadão-repórter? O engajamento do público no jornalismo colaborativo dos grandes portais brasileiros"

Dissertação apresentada ao Programa de Pós-Graduação em Ciências da Comunicação, Área de Concentração Interfaces Sociais da Comunicação, Linha de Pesquisa Tecnologias da Comunicação e Redes Interativas, da Escola de Comunicações e Artes da Universidade de São Paulo, como exigência parcial para obtenção do Título de Mestre em Ciências da Comunicação, sob a orientação da Profa. Dra. Elizabeth Saad Corrêa.

Presidente da banca: Profa. Dra. Elizabeth Saad Corrêa

\section{Banca examinadora:}

$\operatorname{Prof}(a) \cdot \operatorname{Dr}(a)$ Instituição:

Julgamento: Assinatura:

$\operatorname{Prof}(a) \cdot \operatorname{Dr}(a)$ Julgamento: Instituição: Assinatura:

\section{Aprovado em:}

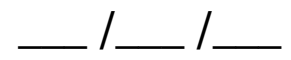


AOS MEUS FILHOS BERNARDO E JÚLIO 


\section{AGRADECIMENTOS}

A Elizabeth Saad, pela contínua atualização e por manter vivos na ECA os Internet Studies A Marilisa Martins, Tereza Rangel, Rodrigo Flores, Lilian Ferreira, Pedro Cirne, Marcelo Coutinho, Vanderlei de Souza, Daniela Ramos, Renato Targa, Ana Brambilla, Alec Duarte e Dominique Giordano pelo apoio e por, cada um de seu modo e a seu tempo, terem me apoiado e inspirado

A Marco Madureira e Regina Bennati, por quem sou

A Orlando e Luiza, pelo carinho e pela dedicação

A Talita de Melo, pelo estímulo, pela compreensão, pelo amor incondicional

A Paulo, Rogério e André, pelo suporte silencioso em todas as horas

A Deus e a todos, pela paciência 


\section{RESUMO}

MADUREIRA, Francisco B. Cidadão-fonte ou cidadão-repórter? 0 engajamento do público no jornalismo colaborativo dos grandes portais brasileiros. São Paulo, 2010. 145 p. Dissertação (Mestrado) - Escola de Comunicações e Artes, Universidade de São Paulo, 2010.

O jornalismo colaborativo ganhou seus primeiros reflexos no Brasil durante a primeira década dos anos 2000. O fenômeno parte do princípio que qualquer cidadão é um jornalista em potencial, e pode contribuir para a construção do noticiário. Para avaliar se a prática foi adotada com o mesmo grau de abrangência que em iniciativas internacionais, empreendemos análise do conteúdo colaborativo publicado nos grandes portais brasileiros, concentradores de tráfego da Internet no país, e entrevistamos jornalistas e publishers destes veículos. Os dados obtidos pelo estudo indicam que o internauta brasileiro que participa dos serviços colaborativos dos grandes portais ainda se concentra na atividade do registro flagrante, primeiro degrau de colaboração. A checagem dos fatos, a apuração e o trabalho de edição verificado no noticiário participativo ainda são objetivos a atingir.

Palavras-chave: jornalismo colaborativo, jornalismo online, jornalismo, Internet, mídias sociais 


\title{
ABSTRACT
}

\begin{abstract}
MADUREIRA, Francisco B. Citizen-source or citizen-reporter? Audience's engajement in major Brazilian Internet portal's collaborative journalism. São Paulo, 2010. 145 p. Dissertação (Mestrado) - Escola de Comunicações e Artes, Universidade de São Paulo, 2010.
\end{abstract}

Collaborative journalism emerged in Brazil during 2000's first decade. It implies considering every citizen a potential reporter, capable of participate in the news process. In order to evaluate if the practice was adopted in major Brazilian Internet portal's - top Web traffic drivers - with the same depth and extent as adopted by international initiatives like OhMyNews, Digg or Slashdot, a series of content analysis were processed in their collaborative content, alongside with interviews with top online journalists and publishers. The collected data revealed the Brazilian Internet user still concentrates in register reality as a mere blatant, considered one of the earlier steps of online collaboration. Fact checking, source research and editing material are still goals to achieve.

Keywords: collaborative journalism, online journalism, journalism, Internet, social media 


\section{SUMÁRIO}

Capítulo 1. Introdução ............................................................................ 11

1.1 Contexto Sócio-comunicacional ....................................................... 14

1.2 A Eclosão do Jornalismo Colaborativo ............................................. 20

Capítulo 2. Jornalismo e Colaboração: Alguns Conceitos ............................. 26

2.1 Jornalismo e Disciplina da Verificação ............................................ 28

2.2 Independência e Compromisso Público .......................................... 30

2.3 Critérios de Noticiabilidade de um Fato ......................................... 33

2.4 Colaboração Online: Alguns Conceitos .......................................... 35

2.5 Jornalismo Colaborativo ..................................................... 42

Capítulo 3. Metodologia ......................................................................... 54

3.1 Objeto, Problema, Justificativa .................................................. 55

3.2 Objetivos e Hipóteses ....................................................... 58

3.3 Procedimentos Metodológicos ...................................................... 60

Capítulo 4. Jornalismo Colaborativo nos Portais Brasileiros ....................... 72

4.1 Flagrante vs. Apuração .............................................................. 79

4.2 Cidadão-repórter, Cidadão-fonte, Cidadão-pauteiro .............................. 85

4.3 Investigação, Divulgação, Credibilidade .......................................... 89

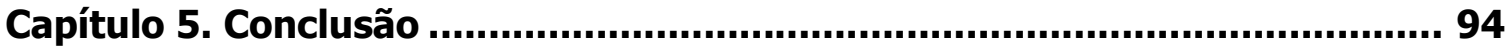

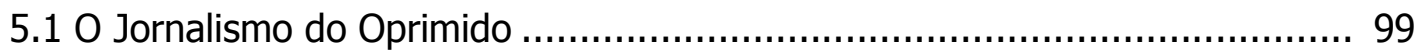

5.2 Jornalismo e Autoria Digital ......................................................... 106

5.3 Motivações da Colaboração e as Raízes do Brasil .................................. 109

Referências ................................................................................................... 115

Anexos .............................................................................................. 125 
"Face a todas as transformações tecnológicas com as quais nos defrontamos, devemos colocar-nos a seguinte pergunta: de que problemas atuais o jornalismo é a solução? Se conseguirmos responder, então o jornalismo jamais desaparecerá."

Ignacio Ramonet 


\section{INTRODUÇÃO}

Caso Clinton-Lewinski. Um dos maiores escândalos das últimas décadas nos Estados Unidos, que conseguiu captar a atenção da imprensa de todo o mundo. O assunto vinha sendo investigado algumas semanas antes do fatídico dia 17 de janeiro de 1998 . Nem a Casa Branca, nem o jornalista investigativo Michael Isikoff, da revista Newsweek, esperavam a publicação de um post no blog de Matt Drudge, então gerente de uma loja de conveniência no edifício da rede de televisão norte-americana $C B S$, sempre atento às conversas de corredor entre os repórteres que frequentavam o lugar. Drudge revelava que a Newsweek havia deixado de publicar naquele fim de semana uma reportagem sobre o envolvimento sexual entre o então presidente Bill Clinton e uma estagiária ${ }^{1}$

Questionável do ponto de vista jornalístico, o "furo" do blog The Drudge Report quase derrubou um presidente. Também "enlouqueceu a imprensa" (RAMONET, 1999, p. 14). E enviou a ela uma mensagem clara -a Internet começava a mudar definitivamente a forma de produzir e consumir informação; os jornalistas não mais eram os únicos "porteiros" (gatekeepers) ou "cães de guarda" (watchdogs) da informação.

Ao reunir as potencialidades de todas as mídias em uma única plataforma, a Internet inicialmente ampliou os horizontes para veículos e jornalistas, que desde a década de 1990 trabalham para descobrir formas de produzir conteúdos em novos formatos para leitores, espectadores e usuários. No Brasil, apesar de as primeiras experiências em jornalismo online terem começado em 1995, só em 2000 é que os grandes grupos de comunicação começaram a explorar de fato um noticiário produzido especificamente para 
a Internet. Foi quando surgiram Estadão.com, Folha Online [que em 2010 mudou de nome para Folha.com], Último Segundo e Veja Online (MOHERDAUI, 2002, p. 57).

Fosse a Internet a simples transposição dos veículos de comunicação existentes em meios analógicos para uma nova plataforma, teríamos a repetição de um fenômeno que ocorrera praticamente um século antes com a invenção do telégrafo:

\begin{abstract}
"A telegrafia foi o primeiro grande avanço da área da eletricidade, descrita em 1889 pelo primeiroministro britânico, o marquês de Salisbury, como uma 'estranha e fascinante descoberta' que tivera influência direta na 'natureza moral e intelectual e nas ações da humanidade'. Ela havia 'reunido toda a humanidade em um grande nível, em que se podia ver [sic] tudo que é feito e ouvir tudo que é dito, e julgar cada política adotada no exato momento em que os eventos aconteciam. (...) Como os canais, ferrovias e ligações oceânicas, também o telégrafo ligou mercados nacionais e internacionais, incluindo bolsas de valores e de mercadorias (algodão, trigo e peixe, por exemplo). Também aumentou a velocidade de transmissão de informação, pública e privada, local e regional, nacional e imperial, e essa característica, a longo prazo, foi seu efeito mais significativo. A distância ia sendo conquistada à medida que se transmitiam informações relativas a governos, negócios, assuntos familiares, condições climáticas e desastres naturais ou provocados pelo homem, a maior parte delas como notícias." (BRIGGS; BURKE, 2006, p. 137)
\end{abstract}

Mas a rede mundial não parou por aí. Diferentemente do telégrafo, cujo acesso era restrito aos próprios veículos de comunicação, em praticamente uma década a Web se transformou em uma plataforma aberta para além dos media, canal de comunicação para 1,8 bilhão de pessoas $^{2}$ cuja voz foi suplantada por décadas pela predominância da televisão, do rádio ou da mídia impressa (QUADROS, 2005, p. 14). A rede mundial de computadores transformou-se também no maior sistema de publicação de conteúdos que a humanidade já conheceu (BOWMAN; WILLIS, 2003, p. 15), com mais de 1 trilhão de páginas no ar já em julho de 2008, de acordo com o Google 3 . São informações que vão além das fronteiras da mídia de massa, publicadas por pessoas comuns, empresas ou órgãos governamentais, homens ou mulheres, crianças ou adultos, simpatizantes das mais diversas religiões e ideologias políticas. Agora qualquer um pode publicar suas ideias na rede mundial de computadores - "estamos vivendo em meio ao maior aumento de

\footnotetext{
${ }^{2}$ Internet Usage Statistics Dec. 2009. Disponível em: <http://www.internetworldstats.com/stats.htm>. Acesso em: 15 jul. 2010

${ }^{3}$ We new the web was big... Disponível em: <http://googleblog.blogspot.com/2008/07/we-knew-web-was-big.html>. Acesso em: 16 jul. 2010.
} 
capacidade expressiva da história da raça humana. Mais pessoas podem comunicar mais coisas a mais pessoas do que jamais foi possível no passado", diz Shirky (2008, p. 106).

Foi no turbilhão deste novo modelo de comunicação que emergiu o fenômeno dos blogs. Pequenos sites, com sistemas de publicação automatizados e muitas vezes gratuitos, eles tornaram possível a pequenas equipes —compostas por jornalistas ou não- disputar cliques com impérios de comunicação. Algo equivalente ao que o formato de música digital MP3, aliado aos sistemas de troca de arquivos P2P (peer-to-peer), fez com a indústria fonográfica na década de 1990. Pesquisa realizada pelo instituto Pew Internet \& American Life Project revelou em 2006 que 8\% dos internautas norteamericanos possuíam um blog, o equivalente então a 12 milhões de pessoas. Destas, $34 \%$ consideravam seu blog uma forma de jornalismo $-56 \%$ com frequência gastavam tempo para verificar a veracidade de informações que publicavam, e 57\% incluíam links para fontes de onde coletavam as informações. Mas estas não são as únicas razões pela qual os blogs representam uma ameaça ao atual modelo de negócios da imprensa. Para $84 \%$ dos blogueiros, escrever é um hobby, e $85 \%$ não almejam ganhar dinheiro com a atividade (LENHART; FOX, 2006). No entanto blogs ainda tendem a ser vistos como meros diários virtuais, que misturam "realidade com imaginação", "onde tudo pode ser colocado, fatos, mentiras, fofocas, versões, insinuações, ilações e até acusações"4

Apesar dos questionamentos sobre credibilidade, jornalistas e cidadãos comuns lançaram mão dos blogs para publicar conteúdo. Entidades de imprensa consideram esses diários virtuais uma ferramenta importante da liberdade de expressão, especialmente em países sob regimes autoritários. A organização internacional Repórteres Sem Fronteiras, por exemplo, tem um "Manual para Blogueiros e Ciberdissidentes"5. Praticamente todos os jornais online possuem blogueiros entre seus colaboradores. Já em abril de 2007, o

4 Jornalismo, profissão em extinção. Disponível em: <http://agenciacartamaior.uol.com.br/templates/materiaMostrar.cfm? materia id=10021 >. Acesso em: 9 dez. 2007.

${ }^{5}$ Handbook for Bloggers and Cyber-dissidents. Disponível em: < http://www.rsf.org/IMG/pdf/handbook bloggers cyberdissidentsGB.pdf>. Acesso em: 9 dez. 2007. 
serviço de busca de blogs norte-americano Technorati contabilizava mais de 70 milhões de blogs ativos no mundo, produzindo 17 posts por segundo ${ }^{6}$.

Em paralelo à popularização dos blogs, outra forma de expressão do (antigo) público começou a emergir na Internet -o jornalismo colaborativo, também chamado jornalismo cidadão, participativo ou "open source", em referência ao tipo de software de códigofonte aberto, desenvolvido em conjunto por uma comunidade de programadores que trocam informações pela Web (BRAMBILA, 2006, p. 68). O fenômeno parte do princípio que qualquer cidadão é um jornalista em potencial e pode contribuir para a construção do noticiário. O conceito também afeta outros ramos da indústria cultural, em particular o editorial -a Wikipedia, por exemplo, é uma enciclopédia colaborativa que permite aos internautas criar, atualizar e corrigir coletivamente o conteúdo dos seus verbetes.

"Pela primeira vez na história moderna", diz o guru norte-americano do jornalismo colaborativo Dan Gillmor (2004, p. 137), "o usuário está verdadeiramente no poder":

\begin{abstract}
"O que o jornalismo open source vem provocar é uma instabilidade em um modelo restritivo, instabilidade esta que começa pela integração de dois polos até então opostos do processo comunicacional midiático: o jornalista e os demais públicos. No noticiário open source, de modo geral, o sujeito que lê pode também escrever notícias, compartilhando responsabilidades e tendo no envolvimento pessoal sua principal moeda de troca. 0 espaço que os media de massa abriam para o público, limitados às sessões de cartas, avançam sobre o território editorial, assumindo as pretensões informativas de um noticiário padrão. Quebra-se, portanto, o monopólio absoluto do controle sobre os meios de publicação, ao que cabe um paralelo à produção colaborativa de software por comunidades que partilham os mesmos interesses e habilidades." (BRAMBILA, 2006, p. 73)
\end{abstract}

\title{
CONTEXTO SÓCIO-COMUNICACIONAL
}

Antes de estabelecermos um foco mais preciso nos desdobramentos do jornalismo colaborativo e nos websites que vamos estudar neste trabalho, porém, cabe-nos uma pequena digressão para abarcar o contexto em que o fenômeno começou a tomar forma. Sob uma óptica mais abrangente, podemos situar o jornalismo colaborativo como reflexo

\footnotetext{
${ }^{6}$ State of the Live Web. Disponivel em: <http://technorati.com/weblog/2007/04/328.html>. Acesso em: 9 dez. 2007.
} 
da cultura pós-moderna do indivíduo, do instantâneo, do leve, do fluido. O novo ponto de vista sugerido pela pós-modernidade transforma o mundo em um mosaico em perpétua mudança, em um jogo que abre mão da significação total e contínua das coisas para trazer à tona a significação de fragmentos em relação às suas origens e, ao mesmo tempo, em relação a cada novo contexto. Em vez das representações unificadas do mundo -que em nosso contexto poderiam ser representadas como a matéria jornalística "fechada" pela redação, com um determinado número de fontes e escrita unicamente sob a óptica do jornalista que a escreveu-, o mundo pós-moderno sugere o bricabraque:

\begin{abstract}
"Derrida considera a colagem/montagem a modalidade primária de discurso pós-moderno. A heterogeneidade inerente a isso (seja na pintura, na escritura ou na arquitetura) nos estimula, como receptores do texto ou imagem, 'a produzir uma significação que não poderia ser unívoca nem estável'. Produtores e consumidores de 'textos' (artefatos culturais) participam da produção de significações e sentidos (daí a ênfase no 'processo', na 'performance', no 'happening' e na 'participação' no estilo pós-moderno). A minimização de autoridade do produtor cultural cria a oportunidade de participação popular e de determinações democráticas de valores culturais, mas ao preço de uma certa incoerência ou, o que é mais problemático, de uma certa vulnerabilidade à manipulação do mercado de massa." (HARVEY, 1989, p. 55)
\end{abstract}

A colaboração online parece ser expressão exata desta "colagem", principalmente quando posta em contraste ao jornalismo tradicional, ligado aos conceitos de mídia de massa e de indústria cultural. Ela surge também em um contexto de saturação de informação na Internet, já que qualquer um pode publicar informações de forma instantânea —fenômeno também ligado à pós-modernidade ou à modernidade "leve" ou "líquida". "O capitalismo pesado, no estilo fordista, era o mundo dos que ditavam as leis, dos projetistas de rotinas e dos supervisores; o mundo de homens e mulheres dirigidos por outros (...), o mundo das autoridades: de líderes que sabiam mais e de professores que ensinavam a proceder melhor." (BAUMAN, 2000, p. 75). A imagem da imprensa e da mídia de massa encaixam-se exatamente nesta visão, enquanto a colaboração online e a Internet, com seu dinamismo e sua pluralidade, distanciam-se dela:

"O capitalismo leve, amigável com o consumidor, não aboliu as autoridades que ditam leis, nem as tornou dispensáveis. Apenas deu lugar e permitiu que coexistissem autoridades em número tão grande que nenhuma poderia se manter por muito tempo e menos ainda atingir a posição de 
exclusividade. (...) Parando para pensar, 'numerosas autoridades' é uma contradição em termos. Quando as autoridades são muitas, tendem a cancelar-se mutuamente, e a única autoridade efetiva na área é a que pode escolher entre elas. (...) O 'líder' foi um produto não-intencional, e um complemento necessário, do mundo que tinha por objetivo a 'boa sociedade', ou a 'sociedade certa e apropriada', e procurava manter as alternativas impróprias à distância. O mundo da 'modernidade líquida' não faz nem uma coisa nem outra. A infame frase de efeito de Margaret Thatcher 'não existe essa coisa de sociedade' é ao mesmo tempo uma reflexão perspicaz sobre a mudança no caráter do capitalismo, uma declaração de intenções e uma profecia auto-cumprida: em seus rastros veio o desmantelamento das redes normativas e protetoras, que ajudavam o mundo em seu percurso de tornar-se carne. 'Não-sociedade' significa não ter nem utopia nem distopia: como Peter Drucker, o guru do capitalismo leve, disse, 'não mais salvação pela sociedade' —sugerindo, ainda que por omissão, e não por afirmação, que, por implicação, a responsabilidade pela danação não pode ficar com a sociedade; a redenção e a condenação são produzidas pelo indivíduo e somente por ele -0 resultado do que o agente livre fez livremente de sua vida." (BAUMAN, 2000, p. 76)

O caminho de descentralização e valorização do indivíduo que o jornalismo colaborativo percorre no cenário da pós-modernidade parece acompanhar o fenômeno quando o enxergamos sob o prisma dos estudos da comunicação. Ao permitir que o (antigo) público passe a ter papel ativo na publicação de conteúdo, a colaboração online subverte a própria teoria clássica da comunicação, que estabelece uma diferenciação rígida de papéis entre emissor e receptor. A participação do usuário na Web aproxima-se mais da abordagem do modelo de recepção, tido por McQuail (2005, p. 74) como um dos quatro modelos de processos de comunicação em massa:

TABELA 1

Modelos de Comunicação de Massa de McQuail

\begin{tabular}{|c|c|c|}
\hline & \multicolumn{2}{|c|}{ Orientação do... } \\
\hline & Emissor & Receptor \\
\hline Modelo de Transmissão & Transferir significado & Processamento cognitivo \\
\hline Modelo de Expressão/Ritual & Performance & $\begin{array}{c}\text { Consumação/Experiência } \\
\text { compartilhada }\end{array}$ \\
\hline Modelo de Publicidade & Exibição competitiva & Atenção do espectador \\
\hline Modelo de Recepção & $\begin{array}{c}\text { Codificação preferencial da } \\
\text { mensagem }\end{array}$ & $\begin{array}{l}\text { Decodificação diferencial/ } \\
\text { Construção do significado }\end{array}$ \\
\hline
\end{tabular}


Segundo MCQUAIL (2005), a abordagem da recepção localiza a atribuição e a construção do significado com o receptor. O autor considera as mensagens midiáticas como "polissêmicas" (têm múltiplos significados), interpretadas de acordo com o contexto e a cultura dos receptores.

\begin{abstract}
"Enquanto a conclusão comum é a que o significado como decodificado não necessariamente (e frequentemente) corresponde ao significado como codificado (apesar da mediação de gêneros convencionais e sistemas de linguagem compartilhados), o ponto mais significante é que a decodificação pode tomar um curso diferente do pretendido. Os receptores podem ler nas entrelinhas e até mesmo reverterem a direção pretendida da mensagem. Claro que este modelo e a teoria a ele associada incorporam diversos princípios-chave: a multiplicidade de significados do conteúdo midiático, a existência de comunidades 'interpretativas' variadas, e a primazia do receptor na determinação do significado." (MCQUAIL, 2005, p. 74)
\end{abstract}

Segundo o autor, a análise da recepção vai de encontro aos princípios do estruturalismo e da semiologia, que presumem que as mensagens são construídas por signos formados por caracteres denotativos e conotativos, dependendo das escolhas feitas pelo emissor. Em outras palavras, para a semiologia, a ênfase da significação está mais na mensagem e em seu processo de codificação. Para McQuail, no entanto, a comunicação é baseada em processos de codificação e decodificação, o que confere o mesmo peso aos papéis do emissor e do receptor — caminho que, segundo o autor, começou a ser trilhado por Stuart Hall e sua teoria crítica já na década de 1970.

Os estudos de McQuail, porém, situam-se na esfera da mídia de massa. Com o advento da Internet, o papel do receptor vai além da simples decodificação diferencial e da construção do significado. O receptor torna-se também emissor, em uma estrutura de rede e de diálogo em que realmente ocorre a subversão das teorias da comunicação que, durante o século 20, debruçaram-se sobre o fenômeno da mídia de massa. Estamos, portanto, diante de um fenômeno das chamadas mídias sociais e das práticas de UGC (User Generated Content, ou Conteúdo Gerado pelo Usuário). 
"Estudar comunicação nos últimos 25 anos é ter presenciado uma explosão de novos fenômenos comunicacionais, possibilitados pelo rápido desenvolvimento de tecnologias da informação e da comunicação cada vez mais sofisticadas. A Arpanet de 1969 abriu caminho para o surgimento da Internet nos anos 1980, criando um novo conduíte para transmissão de dados e comunicações. A estreia da World Wide Web em 1990, que se tornou mais acessível mais tarde com o navegador Mosaic, de 1993, e seus sucessores, produziu um sistema interconectado de documentos pelo qual era possível apresentar informações visuais e verbais, assim como a oportunidade de conectar usuários a uma vasta extensão de obtenção de dados e capacidade analítica. Essas inovações tecnológicas e os enfeites associados de hardware e software tiveram o efeito combinado de transformar o computador em um revolucionário novo meio para comunicação interpessoal, em grupo ou em massa, além de introduzir usuários a um deslumbrante menu de novas capacidades comunicativas." (HARRISON; BARTHEL, 2009, p. 156)

O jornalismo colaborativo também se enquadra no contexto dos Estudos Culturais, especialmente se aceitarmos como válida a visão de que ações partipativas, independentemente de sua plataforma, caracterizam-se como uma prática cultural originária do público —entendido como receptor e como produtor de cultura. Visto como manifestação típica de mídia social, o estudo também pode ser posicionado sob a óptica dos Internet Studies, já que o jornalismo colaborativo só se desdobra em seu potencial no contexto digital, tido aqui como mais que simples rede de computadores, mas como rede de pessoas. Como ressalta Christian Fuchs (2008, p. 122), a Web:

"(...) é um sistema tecnossocial global baseado em uma estrutura descentralizada, formada por redes de computadores que armazenam conhecimento humano transformado em objeto. Atores humanos permanentemente recriam esse mecanismo global de armazenamento de conhecimento ao produzirem novos conteúdos informacionais, comunicarem-se e consumirem conteúdos informacionais existentes no sistema."

Quando falamos em sociedade em rede, no entanto, é imprescindível recorremos a Castells (1999), para quem a revolução da tecnologia da informação é um dos principais pontos de partida para a compreensão de nosso tempo. Toda esta transformação tecnológica afetou, segundo o autor, a relação que estabelecemos com o espaço e com o tempo, categorias básicas de nossa relação com o outro, com o mundo. Em uma primeira análise, o culto do instante renegocia o ritmo cronológico estabelecido pelo fordismo e organiza passado e futuro de acordo com expressões momentâneas e fugazes: 
"A informação instantânea em todo o globo, mesclada a reportagens ao vivo de lugares vizinhos, oferece instantaneidade temporal sem precedentes aos acontecimentos sociais e expressões culturais. (...) Por outro lado, a mistura de tempos na mídia dentro do mesmo canal de comunicação, à escolha do espectador/interagente, cria uma colagem temporal em que não apenas se misturam gêneros, mas seus tempos tornam-se síncronos em um horizonte aberto sem começo, nem fim, nem sequência. A intemporalidade do hipertexto de multimídia é uma característica decisiva de nossa cultura, modelando as mentes e memórias das crianças educadas no novo contexto cultural. (...) Com isso, toda ordenação dos eventos significativos perde seu ritmo cronológico interno e fica organizada em sequência passada e futura das expressões culturais. É efêmera porque cada organização, cada sequência específica, depende do contexto e do objetivo da construção cultural solicitada. Não estamos em uma cultura de circularidade, mas em um universo de temporalidade não-diferenciada de expressões culturais." (CASTELLS, 2006, p. 553)

Relativiza-se o tempo, enquanto as telecomunicações e a Internet engolem o espaço físico, dando a ele uma nova plataforma —transformando o "espaço de lugares" no que Castells chama de "espaço de fluxos". Fluxos, claro, de informação, que na sociedade em rede reconfiguram os vínculos que antes eram predominantemente geográficos.

\begin{abstract}
"O espaço de fluxos é a organização material das práticas sociais de tempo compartilhado que funcionam por meio de fluxos. Por fluxos, entendo as sequências intencionais, repetitivas e programáveis de intercâmbio e interação entre posições fisicamente desarticuladas, mantidas por atores sociais nas estruturas econômica, política e simbólica da sociedade. (...) A primeira camada, o primeiro suporte material do espaço de fluxos, é realmente constituída por um circuito de impulsos eletrônicos (microeletrônica, telecomunicações, processamento computacional, sistemas de transmissão e transporte em alta velocidade -também com base em tecnologias da informação), formando, em conjunto, a base material dos processos que verificamos serem estrategicamente cruciais na sociedade em rede. (...) os lugares não desaparecem, mas sua lógica e seu significado são absorvidos na rede. A infraestrutura tecnológica que constrói a rede define o novo espaço como as ferrovias definiam as 'regiões econômicas' e os 'mercados nacionais' na economia industrial." (CASTELLS, 2006, p. 501)
\end{abstract}

Toda essa transformação em nossas relações com o espaço/tempo são ao mesmo tempo causa e consequência de uma transformação no modo com que nos comunicamos.

"Novas formas e processos sociais [não] surgem em consequência da transformação

tecnológica (...) dado que a tecnologia é a sociedade" (CASTELLS, 1999, p. 25).

\begin{abstract}
"As ferramentas que a sociedade utiliza para criar e manter a si própria são tão centrais à vida humana como a colmeia para a vida das abelhas. Apesar de a colmeia não ser parte de nenhuma abelha individualmente, é parte da colônia, moldada pelas abelhas e também moldando a vida de suas habitantes. A colmeia é um aparelho social, um fragmento de tecnologia da informação das abelhas que provê uma plataforma, literalmente, para a comunicação e a coordenação que mantém a colônia viável. Abelhas individuais não podem ser compreendidas separadamente de sua colônia ou de seus ambientes compartilhados e co-criados. Assim também é com as redes humanas; abelhas criam colmeias, nós criamos telefones celulares." (SHIRKY, 2008, p. 17)
\end{abstract}


E este cenário de mudança, mistura, cruzamento e multiplicação de vozes, esta verdadeira renegociação de espaços e tempos, expressa-se no âmbito da comunicação como um processo chamado por Jay David Bolter de re-mediação - verdadeiro paradoxo do tempo real versus contextualização, em que "emissores, receptores, mensagens e ambiente -elementos do processo comunicativo - passam por transformações para incorporar as novas tecnologias e, ao mesmo tempo, manter suas funções originais." (SAAD, 2003, p. 57)

\section{A ECLOSÃO DO JORNALISMO COLABORATIVO}

Voltemos ao surgimento do jornalismo colaborativo - agora compreendendo, porém, que o fenômeno surge em meio a uma reacomodação de terreno pela qual passam pessoas, governos, empresas -e também os principais veículos de comunicação, diante do conteúdo gerado pelo usuário. Conforme chegamos ao final dos anos 2000, estudo realizado pelo Pew Project for Excellence in Journalism ${ }^{7}$ detecta que os sites de noticiário colaborativo continuam a evoluir, mas não de forma a tomar a posição dos veículos de mídia tradicionais, como era temido no início da década. Ao contrário, ambas as práticas parecem iniciar um processo de fusão, particularmente no noticiário regional. Enquanto isso, o (antigo) público continua um movimento para novas formas de comunicação -a frequência de criação e a atualização de blogs têm diminuído, enquanto $26 \%$ dos norteamericanos já leem notícias em seus telefones celulares e $50 \%$ dos internautas que estão em redes sociais acessam o noticiário por dentro destes sites.

O fenômeno da colaboração online no jornalismo teve sua origem nos Estados Unidos e na Ásia entre o final dos anos 1990 e continuaram a se desenvolver durante a década seguinte. Um dos primeiros exemplos foi o site Indymedia (www.indymedia.com), criado

${ }^{7}$ The State of the News Media 2010: An Annual Report on American Journalism. Disponível em: < http://www.stateofthemedia.org/ 2010/online summary essay.php>. Acesso em 17 jul. 2010. 
em 1999 por organizações independentes de mídia e ativistas para uma cobertura alternativa do Fórum da OMC (Organização Mundial do Comércio), em Seattle (EUA).

Outro é o site de tecnologia Slashdot.org (http://slashdot.org) —com estrutura de blog, é uma comunidade que "permite a participação de múltiplas vozes, ao mesmo tempo em que gerencia a ordem social e provê um filtro útil à discussão" (BOWMAN; WILLIS, 2005). Outro ícone da participação nos EUA é o Digg (http://www.digg.com), em que é possível publicar suas próprias histórias, ou então links para matérias e vídeos da imprensa tradicional e votar nos conteúdos que Ihe interessam —um algoritmo do site então posiciona os assuntos mais votados em destaque na primeira página.

Mas é o site sul-coreano OhMyNews (http://www.ohmynews.com), fundado em janeiro de 2000, que detém a aura de ícone do jornalismo colaborativo.
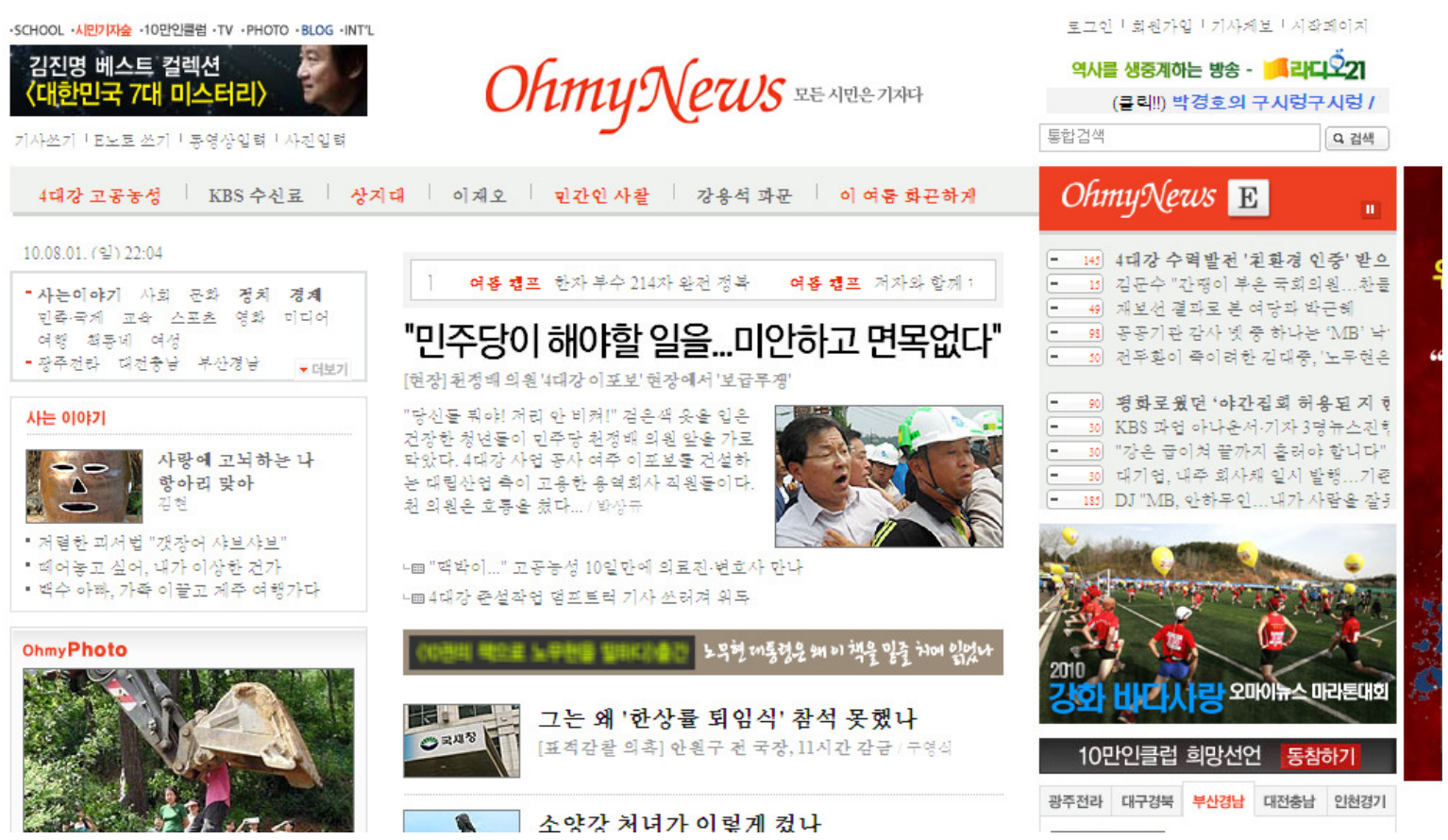

O site de jornalismo colaborativo OhMyNews (http://www.ohmynews.com), da Coreia do Sul

Para participar, não é preciso ser jornalista. Mas é preciso preencher um cadastro detalhado, com reprodução do passaporte, carteira de motorista e identidade. O site chegou a operar em 2004 com 54 jornalistas nas funções de redatores, repórteres e editores, e um ano depois publicava uma média de 150 textos por dia após revisão e 
checagem de dados ${ }^{8}$. Em seu país de origem, o OhMyNews obteve tal grau de influência no cenário noticioso a ponto de ser o primeiro veículo a entrevistar o então presidente eleito Roh Moo Hyun, em 2002. Em 2009, cerca de 70 mil pessoas colaboravam com a produção local de informações, e a versão internacional do site, em inglês (http://english.ohmynews.com), contava com cerca de 6.000 colaboradores $^{9}$. 0 site porém também sentiu a crise econômica que atingiu o setor de publicidade e mídia como um todo nesta época -no mesmo ano, quando tinha um tráfego de 2,5 milhões de páginas vistas por dia e ocupava a 30a colocação entre os sites mais vistos da Coreia do Sul, seu fundador Oh Yeon Ho revelou que a operação estava no vermelho já havia três anos, e veio a público para pedir ajuda financeira aos leitores ${ }^{10}$.

Em meio à eclosão do jornalismo colaborativo pelo mundo, os principais portais brasileiros lançaram durante os anos 2000 suas iniciativas de participação, entre eles o Minha Notícia, do iG (http://minhanoticia.ig.com.br); o VC no G1, da Globo.com (http://q1.globo.com/vc-no-q1); e o VC Repórter, do Terra (http://noticias.terra.com.br/ vcreporter). Há uma importante ressalva a fazer ao cenário brasileiro em relação às iniciativas de jornalismo colaborativo nos Estados Unidos e na Coreia do Sul, analisadas por autores como Brambila (2006), Bruns (2005) ou Gillmor (2004) -a baixa penetração da Internet no país em comparação às regiões de origem destes outros websites. O Brasil é ainda hoje o país da televisão -93,1\% dos domićílios tinham em 2009 pelo menos um aparelho de TV, enquanto apenas $16 \%$ deles possuíam acesso à Internet ${ }^{11}$. Na Coreia do Sul, ambiente estudado por Brambilla (2006), a Internet em banda larga chegava a 60\%

8 "Korean online newspaper enlists army of 'citizen reporters'." Disponível em: < http://www.sfgate.com/cgi-bin/article.cgi?f= LC/a/2005/09/18/MNG7LEPL151.DTL>. Acesso em: 19 set. 2007.

9 "The Struggles of OhMyNews". Disponível em: < http://www.forbes.com/forbes/2009/0330/050-oh-my-revenues.htm>. Acesso em: 26 mai. 2010

10 "Korea's OhMyNews Seeks a Fresh Business Model". Disponível em: < http://www.businessweek.com/globalbiz/content/ jul2009/gb20090714 537389.htm>. Acesso em: 26 mai. 2010

${ }^{11}$ Pesquisa Nacional por Amostra de Domicílios. IBGE, 2009. Disponível em: < $\underline{\text { http://www.ibge.gov.br/home/estatistica/populacao }}$ trabalhoerendimento/pnad2007/sintesepnad2007.pdf>. Acesso em: 31 mar. 2009. 
da população em $2007^{12}$. Segundo o IBGE (Instituto Brasileiro de Geografia e Estatística), o país contava em março de 2009 com uma população de 190,9 milhões de habitantes. Um mês antes, painel do Ibope Nilsen Online revelava que 62,3 milhões de brasileiros possuíam acesso à Internet nos diversos ambientes -residências, trabalho, escolas, lanhouses, bibliotecas, telecentros. Como resultado, é possível concluir que $32,6 \%$ da população brasileira tinha acesso à Internet no início de 2009, índice pouco superior à penetração da web nas Américas do Sul e Central, porém muito aquém dos índices de penetração registrados na América do Norte, na Oceania e na Europa.

TABELA 2

Uso da Internet no Mundo e Estatísticas Populacionais

\begin{tabular}{c|c|c|c|c}
\hline Regiões do mundo & $\begin{array}{c}\text { População } \\
\text { (Est. 2009) }\end{array}$ & $\begin{array}{c}\text { Internautas } \\
\text { (Dez/ 2009) }\end{array}$ & $\begin{array}{c}\text { Penetração } \\
\text { (\% Pop.) }\end{array}$ & $\begin{array}{c}\text { Internautas } \\
\text { por Região }\end{array}$ \\
\hline América do Norte & $340,831,831$ & $259,561,000$ & $76.2 \%$ & $14.4 \%$ \\
\hline Oceania / Austrália & $34,700,201$ & $21,110,490$ & $60.8 \%$ & $1.2 \%$ \\
\hline Europa & $803,850,858$ & $425,773,571$ & $53.0 \%$ & $23.6 \%$ \\
\hline América Latina/Caribe & $586,662,468$ & $186,922,050$ & $31.9 \%$ & $10.4 \%$ \\
\hline Oriente Médio & $202,687,005$ & $58,309,546$ & $28.8 \%$ & $3.2 \%$ \\
\hline Ásia & $3,808,070,503$ & $764,435,900$ & $20.1 \%$ & $42.4 \%$ \\
\hline África & $991,002,342$ & $86,217,900$ & $8.7 \%$ & $4.8 \%$ \\
\hline TOTAL MUNDIAL & $\mathbf{6 , 7 6 7 , 8 0 5 , 2 0 8}$ & $\mathbf{1 , 8 0 2 , 3 3 0 , 4 5 7}$ & $\mathbf{2 6 . 6} \%$ & $\mathbf{1 0 0 . 0} \%$ \\
\hline Fonte: Internet World Stats. Disponível em: $\%$ http://www.internetworldstats.com/stats.htm>. Acesso em: 17 jul. 2010
\end{tabular}

Esta é uma das razões pelas quais decidimos nos debruçar sobre o jornalismo colaborativo empreendido pelos grandes portais de conteúdo brasileiros -eles são concentradores de audiência e portanto potenciais difusores do noticiário participativo. Buscamos compreender se estes ambientes de mídia conseguem despertar nos brasileiros engajamento semelhante ao das iniciativas internacionais analisadas por autores como Brambila (2006), Bruns (2005) e Gillmor (2004). Como é a relação do (antigo) público com as redações destes portais? O internauta brasileiro é realmente, para estes websites, protagonista do processo noticioso, como prega Gillmor (2004, p. 237)?

12 Contemporary Culture: The Internet. Official Seoul City Tourism Website, 2007. Disponível em: <http://english.visitseoul.net/ visit2007en/aboutseoul/culture/culture.jsp?cid=49\&sid=524>. Acesso em: 8 ago. 2009 
Para conhecer um pouco mais sobre o estado e o engajamento do internauta brasileiro com o jornalismo colaborativo nestes ambientes midiáticos, discorremos inicialmente no capítulo 2 sobre conceitos do jornalismo e da colaboração, para então buscar autores que, durante a década passada, estabeleceram os pilares e as primeiras análises da participação do público no noticiário online. Com isso tentamos compreender os princípios norteadores de um tipo de narrativa jornalística que surgiu no século 19 e consolidou-se como ciência durante o século 20, e buscamos também autores que nos dessem bases de análise para modelos e níveis de colaboração e participação em rede para o jornalismo.

A partir destas definições preliminares, fazemos então no capítulo 3 a descrição da metodologia utilizada para analisar o produto final dos grandes portais brasileiros na área de colaboração jornalística, que envolveu um levantamento exploratório do noticiário colaborativo de Minha Notícia (iG), VC no G1 (Globo.com) e VC Repórter (Terra).

No capítulo 4 tecemos uma análise detalhada do noticiário destes dois últimos veículos, comparando suas características às premissas teóricas exploradas anteriormente, para concluir que a adoção de conteúdo gerado pelo usuário nos grandes portais brasileiros ainda encontra-se no primeiro degrau de interatividade possível dentro do jornalismo colaborativo, segundo os autores estudados. Combinamos a análise a entrevistas com diretores de redação, editores de veículos colaborativos e jornalistas com experiência em Internet para enriquecer o debate e a análise sobre o estado atual e o futuro do jornalismo colaborativo nestes ambientes de mídia.

Por fim, capítulo 5 buscamos fazer apontamentos para estudos futuros, baseados em questões que surgiram durante nossa exploração e que podem ajudar a aprofundar o conhecimento sobre a participação do (antigo) público nos meios de comunicação, criando caminhos para a profusão da prática no Brasil. Primeiro, criando um paralelo entre os objetivos do jornalismo colaborativo e a pedagogia do oprimido de Paulo Freire, para que a participação do leitor/espectador/usuário na construção do noticiário se torne 
uma forma de reconectar a pessoa à sua realidade, ao seu contexto, ao seu entorno, reinserindo-a de forma crítica na sociedade de que faz parte, da qual muitas vezes se vê afastado pela atitude que a imprensa em geral toma em relação ao noticiário. Em seguida, indicamos a necessidade de estudos mais detalhados sobre a atuação do jornalista neste novo contexto colaborativo, em que o advento da mídia digital e da comunicação em rede transformaram o conceito de autoria. Por fim, apontamos também um aprofundamento no estudo da realidade brasileira e as limitações do engajamento de nosso público com o jornalismo colaborativo, traçando um breve contexto de nossas raízes históricas, de forma a evitar a mera importação de estruturas de produção e consumo de conteúdo que, sem a devida adaptação, podem tornar-se fator de alienação em vez de libertação.

Convidamos então o leitor a iniciar nossa jornada argumentativa pela compreensão de alguns princípios que norteiam o jornalismo e a colaboração online. 


\section{JORNALISMO E COLABORAÇÃO: ALGUNS CONCEITOS}

Com fins metodológicos, e para sustentar as análises quantitativas e qualitativas a que submeteremos o noticiário participativo dos grandes portais brasileiros, faz-se necessário pontuar alguns conceitos relativos ao jornalismo, à colaboração online e ao jornalismo colaborativo em si. Iniciemos pelo jornalismo. Um breve percurso etimológico nos leva até "jornal", que deriva do francês arcaico "journal", cujos primeiros registros de uso datam do século $12^{13}$. Por sua vez, o termo francês deriva das palavras latinas "diurnus" (do dia, ou diário) e "dies" (dia, luz do dia, dia específico). E então podemos chegar a uma das noções possíveis de noticiário como resumo dos acontecimentos "do dia" (ou de um determinado período de tempo), que envolve o trabalho de:

\footnotetext{
"(...) coleta, preparação e distribuição de notícias, comentários relacionados e materiais especiais por meios como panfletos, boletins, jornais, revistas, rádio, vídeo, televisão e livros. A palavra 'jornalismo' foi originalmente aplicada à reportagem de fatos atuais em forma impressa, especificamente em jornais, mas com o advento do rádio e da televisão no século 20 o uso do termo se ampliou para incluir toda a comunicação impressa ou eletrônica que trate de assuntos atuais." ${ }^{14}$
}

Sob uma óptica deontológica, a caracterização de jornalismo e de notícia remonta à segunda metade do século 19, com o surgimento da empresa jornalística e da figura do correspondente, em especial o de guerra. A Guerra Civil norte-americana seria um dos primeiros conflitos de guerra que teria uma cobertura jornalística extensiva (TRAQUINA, 2005 , p. 7). Começa a surgir entre os jornais a ideia de que a imprensa deveria correr atrás da notícia, encher as páginas de jornais com assuntos que interessassem aos leitores.

\footnotetext{
${ }^{13}$ MYETYMOLOGY. Disponível em: <http://www.myetymology.com/french/journal.html>. Acesso em: 17 abr. 2009.

${ }^{14}$ BRITANNICA ONLINE. Disponível em: <http://www.britannica.com/EBchecked/topic/306742/journalism>. Acesso em: 17 abr. 2009.
} 
Essa expansão da imprensa trouxe também uma maior divisão de trabalho, o que tornou as redações ambientes mais complexos e burocráticos. A figura do repórter, que emerge no final do século 19, surge como esta figura que deve "correr atrás da notícia", enquanto o jornal passa a publicar fatos, e não mais apenas opiniões. Para tanto, 0 jornalista desenvolve técnicas que transformam o trabalho de reportagem numa espécie de ciência, distinguindo-o do tom opinativo que predominou no jornalismo até então.

\begin{abstract}
"Com o desenvolvimento da reportagem, e em particular a grande reportagem, o jornalismo ganha algum prestígio. É só em fins dos anos 1880 que a grande reportagem se torna um ingrediente essencial do jornalismo em França. Na virada do século, nota Bernard Voyenne, a conotação da palavra 'repórter' mudou completamente. $\mathrm{O}$ termo, que designava 'a mais humilde categoria das gentes da imprensa', vai tornar-se 'como por uma metamorfose à vista desarmada, uma das mais prestigiadas e invejadas'. (TRAQUINA, 2005, p. 78)
\end{abstract}

Segundo Kovach e Rosenstiel (2004, p. 31), a prática jornalística apoiada na reportagem tem por finalidade fornecer aos cidadãos informações de que necessitam para serem livres e se autogovernar. Ela deve obedecer a alguns princípios para a sobrevivência da imprensa livre -entre eles, os principais à nossa análise são a necessidade da apuração de informações, a independência e o compromisso público (2004, p. 22). Adiante pretendemos desenvolver cada um destes três tópicos fundadores da prática jornalística, que, consideramos, também devem nortear práticas colaborativas que pretendam-se jornalismo. 


\title{
JORNALISMO E DISCIPLINA DA VERIFICAÇÃO
}

Segundo Smith ${ }^{15}$ (1978 apud TRAQUINA, 2005, p. 58), "a estenografia foi a primeira de uma longa série de técnicas jornalísticas que a princípio pareceu prometer ao leitor a recuperação completa de alguma semelhança com a realidade". Era uma forma de contar histórias, trazer testemunhos da realidade ao texto. Emerge então entre os profissionais da imprensa escrita a técnica da entrevista, assim descrita por Traquina (2005, p. 59):

\begin{abstract}
"A técnica da entrevista foi utilizada pela primeira vez por um dos primeiros jornais da nova peny press, The New York Herald, numa reportagem sobre um crime que teve lugar num bordel, com uma entrevista com a proprietária do negócio. (...) Não só as peças noticiosas incluíam cada vez mais fontes múltiplas, apresentando uma diversidade de pontos de vista no mesmo artigo, como também os jornalistas demonstraram ainda mais agressividade na obtenção de elementos informativos: a prática de correspondentes do Norte durante a Guerra Civil norte-americana, de viajar disfarçados no Sul para evitar serem detectados, forneceu um modelo para o 'jornalismo de disfarce' que se desenvolveu nos anos de 1880. (...) Outro importante desenvolvimento, demonstrativo do crescente poder da imprensa, seria o surgimento do jornalismo de investigação, com os chamados jornalistas muckrakers no fim do século XIX e início do século XX."
\end{abstract}

O lançar-se para o mundo a fim de obter testemunhos passa então a ser a principal técnica jornalística, uma forma de espelhar a realidade, trazê-la sob seus mais diversos ângulos às páginas que informarão os leitores. Ao debruçar-se sobre os fatos -e não mais meramente servir como repositório de opiniões, fossem elas do dono do jornal ou de seus afetos—, o veículo de imprensa passa a utilizar o processo de apuração e checagem de dados como procedimento de atribuição de credibilidade à construção do noticiário. É exatamente este princípio que caracteriza uma narrativa como jornalística, distinguindo-a da ficção, do texto dissertativo ou opinativo.

A disciplina da verificação também separa o jornalismo do entretenimento, da propaganda, da literatura ou da arte (KOVACH; ROSENSTIEL, 2004). Diferente da ficção,

\footnotetext{
${ }^{15}$ SMITH, Anthony. The Long Road to Objectivity: The Kinds of Truth We Get in Journalism". Newspaper History: From the Seventeenth Century to the Present Day. London: Constable e Bervely Hills, Ca: Sage Publications, 1978.
} 
obra inspirada pela imaginação, pela criatividade e pela subjetividade do autor, escrever notícias exige que o jornalista vá ao encontro de pessoas ou instituições que possuam informações. Não pretendemos neste ponto do trabalho adentrar o vasto campo de investigação da subjetividade no texto jornalístico, já exaustivamente discutido na academia por áreas como a semiologia ou a teoria da comunicação. Nem, de outra forma, demover do jornalista sua capacidade criativa na construção das peças informativas e das maneiras com que pode melhor informar seu leitor acerca de um tema utilizando-se de diversas técnicas narrativas. Pretendemos apenas, com fins metodológicos, diferenciar a subjetividade do texto ficcional da por assim dizer almejada objetividade do texto jornalístico, baseado em observação, em depoimentos de terceiros, em documentos obtidos junto a empresas ou instituições públicas. Diferenciar, portanto, o trabalho do escritor do trabalho do repórter, figura mais importante de uma redação, segundo Nilson Lage (2001, p. 49):

\begin{abstract}
"Poucas matérias jornalísticas originam-se integralmente da observação direta. A maioria contém informações fornecidas por instituições ou personagens que testemunham ou participam de eventos de interesse público. São o que se chama de fontes. É tarefa comum dos repórteres selecionar e questionar essas fontes, colher dados e depoimentos, situá-los em algum contexto e processá-los segundo técnicas jornalísticas."
\end{abstract}

A checagem da informação de maneira sistemática é, portanto, um dos princípios da atividade jornalística, e deve nortear a construção de qualquer narrativa que se pretenda jornalismo, seja em plataforma analógica ou digital. Deste ponto de vista, podemos inferir que sites colaborativos e até blogs, mesmo os autorais, só podem ser considerados jornalísticos quando agregam informações de diversas fontes, de preferência as chamadas fontes primárias, que têm relação direta com o fato, são suas testemunhas, ainda que tenham seu relato influenciado pela emoção, pelos preconceitos, pela memória e pela própria linguagem (PENA, 2005, p. 64). 


\section{INDEPENDÊNCIA E COMPROMISSO PÚBLICO}

A independência é outro fator ligado à credibilidade e à ética jornalística. Segundo Kovach e Rosenstiel (2004, p. 164), esta última significa uma "maneira de ser jornalista sem negar a experiência pessoal, mas sem também se tornar refém dela". Em primeiro lugar, o jornalista deve ser independente daquilo que noticia. Esta independência nos interessa, em um primeiro olhar, pelo distanciamento que provoca entre o fato em si e sua narrativa, a avaliação crítica dos detalhes abordados pelo repórter e a seleção descompromissada das fontes. Independência que faz de um press release - texto de divulgação de empresas ou órgãos públicos normalmente produzido por jornalistas- uma peça normalmente enviesada, em que a relação de independência entre o autor do material e seu objeto é quebrada pelo pagamento de um soldo. Independência que leva Lage (2001, p. 95) a criticar a proliferação das fontes institucionais, que contariam por cerca de $60 \%$ de tudo o que é publicado na imprensa norte-americana. No caminho inverso, a teoria de Kovach e Rosenstiel propõe que o jornalismo forneça um fórum para a crítica pública e a conciliação, com a mínima interferência de discursos que fujam à verdade, aos fatos e à verificação. 0 desafio em um cenário de mídias sociais em que qualquer um tornou-se um emissor de informações pela rede é diferenciar o discurso jornalístico do discurso privado maquiado de jornalismo. Dizem os autores (2004, p. 24):

\footnotetext{
"Pela primeira vez em nossa história, mais e mais as notícias são produzidas por empresas nãojornalísticas (...). Existe o risco de que a informação independente seja substituída por um comercialismo egoísta fazendo pose de jornalismo. Se isso acontecer, perderemos a imprensa como instituição independente, livre para vigiar as outras poderosas forças e instituições existentes na sociedade."
} 
Porém este temor também faz Kovach e Rosenstiel criticarem o envolvimento do jornalista com sua própria realidade. Para os autores, a atividade jornalística demanda uma "independência engajada" —algo que define o papel do jornalista como alguém dedicado a informar o público, e não participar de alguma causa ou movimento social. Na década de 1990, foi comum nas redações dos EUA repreensões, mudanças de cargo e até mesmo demissões pelo envolvimento de repórteres em atividades político-partidárias, como manifestações pela igualdade dos sexos, em favor ou contra o aborto ou demonstrações contra guerras. No Brasil, já presenciamos questionamentos a colegas por comparecerem à redação com a camisa de um time de futebol —como se, em horário comercial, ele pudesse de alguma forma deixar de lado suas convicções, sentimentos, vontades. Mais uma vez, nosso objetivo aqui não é adentrar a discussão da subjetividade no texto jornalístico. Mas evidenciar uma das facetas da tal busca (ainda que utópica) pela objetividade, que leva os jornalistas a acreditarmos ser nossa causa primeira levar a notícia ao público, antes de qualquer outro tipo de engajamento ideológico.

Já presenciamos, porém, o uso deste exato argumento por um dirigente de redação para justificar à equipe jornadas de trabalho de 14 a 16 horas durante os ataques ao World Trade Center, nos Estados Unidos, em 2001. Afinal, se a missão do jornalista é informar, qual o problema de fazer jornadas de trabalho estendidas, perder fins de semana ou sua própria vida pessoal? O jornalista, neste contexto, está agindo a serviço do público, ou a serviço de interesses empresariais? Busca-se a informação para simplesmente fazer circular periódicos e vender publicidade, ou busca-se algum comprometimento com o público e sua realidade?

Com esta combinação de ingredientes, a "independência engajada" pode servir de discurso empresarial e afastar o jornalismo do interesse público —como defende o próprio Código de Ética dos Jornalistas Brasileiros, que em seu artigo $6^{\circ}$ define o exercício da profissão como "de natureza social, e de finalidade pública". Um dos fundadores desta 
visão crítica do jornalismo sobre si mesmo foi o jornalismo cívico, que tentou repensar a motivação da profissão.

O jornalismo cívico ou público ${ }^{16}$ surgiu na contra-mão desta "independência engajada" defendida por Kovach e Rosenstiel. Pena (2005, p. 170) cita o exemplo do jornal norteamericano Columbus Ledger Enquirer, da Geórgia, que em 1988 abandonou a cobertura tradicional, encomendou uma pesquisa sobre os principais problemas de sua região, participou da organização de associações de cidadãos e abriu mais espaço para as cartas de leitores, além de direcionar a maior parte de seu conteúdo para assuntos regionais. Se não podemos chamar o jornalismo cívico de antecessor do jornalismo colaborativo, já que o primeiro mantinha a imprensa no centro do processo comunicativo, este movimento do jornal em direção ao público inicia uma abertura de diálogo que a colaboração online viria ampliar uma década mais tarde, como veremos adiante. Ao mesmo tempo, a prática do jornalismo cívico tendia a resgatar o interesse público no jornalismo, afastando-o de manobras de instituições públicas ou entidades privadas. Como diz Chaparro (1993, p. 120), "a complexidade dos conflitos em que interage e a preponderância do componente interesse nesses conflitos impõem ao jornalista o dever vital de se conectar a princípios éticos. Esses princípios devem determinar as intenções controladoras das ações jornalísticas, tendo como motivo o interesse público."

\footnotetext{
"A função social do jornalismo [deve] ser entendida numa perspectiva mais alargada, cabendo-Ihe impulsionar uma vida pública mais democrática, o que significa formar o público, e não meramente informá-lo. O jornalista deixa, assim, de ser entendido enquanto observador distanciado da vida pública para ser reposicionado enquanto participante justo, comprometido com a melhoria da participação, do debate e da deliberação públicas." (BORGES, 2009, p. 1)
}

\footnotetext{
${ }^{16}$ O professor da Universidade de Nova York Jay Rosen, um dos primeiros teóricos do jornalismo cívico ou público, define-o como "uma abordagem para a atividade diária do ofício que convoca os jornalistas a (1) considerar as pessoas como cidadãs, potenciais participantes dos assuntos públicos, e não apenas vítimas ou espectadores; (2) ajudar a comunidade política a agir sobre seus problemas, mais que simplesmente saber sobre eles; (3) melhorar o clima da discussão pública, mais do que simplesmente observá-lo deteriorar; e (4) ajudar a melhorar a vida pública (...) Se os jornalistas descobrirem uma maneira de fazer estas coisas, eles podem oportunamente restaurar a confiança do público na imprensa e se reconectar com um público que foi se afastando." (GLASSER, 1999, p. 22)
} 


\section{CRITÉRIOS DE NOTICIABILIDADE DE UM FATO}

À nossa avaliação dos serviços de jornalismo colaborativo dos grandes portais brasileiros também interessará compreender o que torna um fato notícia, os valoresnotícia ou critérios de noticiabilidade utilizados tanto pelos editores destes sites e também pelos cidadãos-repórteres — cujo trabalho será avaliado no estudo quantitativo.

O interesse é o atributo de definição do jornalismo, segundo Chaparro. "Só é notícia o relato que projeta interesses, desperta interesses ou responde a interesses." (1993, p. 120). O interesse por si só, no entanto, é uma categoria extremamente vaga. O que é interessante para mim pode não ser a você, leitor. O que interessa a um grupo ou região pode não interessar a outra. Como fugir da subjetividade, pois? Uma das formas é buscar atributos de relevância, que podem potencializar ou reduzir o interesse sobre um fato para determinado público. Para Chaparro, quanto mais numerosos e mais intensos forem os atributos de relevância de um dado conteúdo, maior será o nível de interesse desse conteúdo para o leitor. Estes atributos, segundo o autor, são:

\section{TABELA 3}

Atributos de Relevância de uma Notícia

\begin{tabular}{ccc}
\hline Atualidade & Conflito & Conhecimento \\
Consequências & Curiosidade & Dramaticidade \\
Notoriedade & Proximidade & Surpresa \\
\hline Fonte: CHAPARRO, 1993, p. 120 & &
\end{tabular}


Ao entrevistar os editores do telejornal RJTV, no Rio de Janeiro, Alfredo Vizeu ${ }^{17}$ (2000, apud PENA, 2005, p. 74) registra em sua tese de mestrado os critérios de noticiabilidade utilizados na seleção de fatos que se tornam notícia. A lista é semelhante:

\section{TABELA 4}

Critérios de Noticiabilidade de um Telejornal

\begin{tabular}{ccc}
\hline & Uma notícia de telejornal deve... \\
\hline Ser factual & Despertar o interesse do público & Atingir o maior número de pessoas \\
Trazer coisas inusitadas & Abordar novidades & Incluir personagens \\
Ter boas imagens & \\
\hline Fonte: Adaptado de PENA, 2005, p. 74
\end{tabular}

A não ser pelo último critério, específico do universo da televisão, Vizeu enxerga basicamente as mesmas balizas que Chaparro. Valores-notícia semelhantes surgem nas obras de Aldé et al. (2005) e Silva (2005). Porém, não há consenso ou escrituras consagradas sobre o tema - a subjetividade, o jogo complexo de intenções e forças que regem a escolha de uma manchete ainda é objeto de estudo e aprofundamento entre os próprios acadêmicos do jornalismo, algo que está além até mesmo dos manuais de redação, que tentam, segundo Chaparro, "impor uma linguagem-padrão e normas de ação" para a criação, em escala industrial, de um produto com determinados padrões de conteúdo e forma. Diz, porem, o autor (1993, p. 100), que:

"(...) os manuais não conseguem se sobrepor aos interesses particulares dos diversos intervenientes -talvez porque, como sentenciou Kant, interesse não pode ser imposto, mas é uma categoria da liberdade, do amor-próprio, um ato livre da vontade."

\footnotetext{
${ }^{17}$ VIZEU, Alfredo. Decidindo o que é notícia: os bastidores do telejornalismo. Porto Alegre: EDIPUCRS, 2000.
} 
Para identificar, no entanto, quais as intenções e de que atributos de relevância os cidadãos-repórteres e editores de serviços colaborativos dos grandes portais lançam mão para selecionar os fatos abordados, vamos considerar os critérios de noticiabilidade eleitos por Chaparro, procurando identificar, em nossa análise quantitativa empreendida no capítulo 4, quais deles cada notícia analisada possui.

\section{COLABORAÇÃO ONLINE: ALGUNS CONCEITOS}

Antes de chegar às abordagens mais recentes sobre o jornalismo colaborativo, faremos um breve caminho em torno da definição de colaboração em si. A etimologia da palavra revela raízes no prefixo latino "com" (em conjunto com) e no termo latino "labor" (trabalho, esforço, preocupação) ${ }^{18}$. Poderíamos traduzi-la, portanto, como trabalho conjunto, preocupação compartilhada, esforço reunido em torno de um objetivo comum.

Aprofundar as origens da colaboração entre seres humanos mereceria um estudo acadêmico próprio e muito mais profundo, que não empreenderemos aqui. Cabe-nos, no entanto, distinguir o processo de trabalho conjunto como raiz da vida em sociedade, com origens muito anteriores às da própria mídia, da própria escrita. Shirky (2008, p. 14) aponta de forma clara e sucinta que "sempre dependemos de esforços em grupo para sobreviver; mesmo antes da invenção da agricultura, a caça e a coleta exigiam coordenação e trabalho em equipe".

Em um plano ligado à Comunicação e aos estudos da mídia, podemos situar a colaboração como fenômeno das mídias digitais, associado especialmente ao surgimento da Internet, em contraste à primazia do emissor sobre o receptor no contexto da mídia de massa. Suas bases conceituais, no entanto, começaram a se formar antes mesmo do advento da Web, com a chamada "virada interpretativa" que os Estudos Culturais

18 MYETYMOLOGY. Etymology of the English word collaborate. Disponível em: < http://www.myetymology.com/english/ collaborate.html>. Acesso em: 03 mai. 2010. 
promoveram na segunda metade do século 20. Este movimento transforma a figura do receptor em personagem ativo, independentemente da plataforma tecnológica, e como vimos anteriormente defende a autonomia do leitor de um texto na criação de significados, libertando-o de um papel absolutamente passivo em relação ao emissor:

"(...) a reação do receptor tornou-se popular nos anos 1970 e privilegiava a participação ativa do receptor ao moldar o significado de um texto através de atos interpretativos. De fato, desvendar o significado objetivo do texto, somado à primazia do autor na criação e na condução deste significado, foi uma preocupação central de campos que participaram da 'virada interpretativa' das ciências humanas no final do século 20. (...) Desde então, o conceito de 'leitura transacional', na qual leitores e autores co-constróem o significado de um texto, tornou-se a hipótese padrão nos Estudos Culturais, nos estudos da recepção e nos estudos da mídia." (HARRISON; BARTHEL, 2009, p. 163)

Segundo Harrison e Barthel (2009), desde sempre leitores puderam inventar seus próprios finais para as histórias que liam. Mas antes da Internet estas visões tendiam a permanecer somente com eles, ou no máximo atingir círculos limitados de amigos. Com o advento da rede e de ferramentas interativas como fóruns e redes sociais, no entanto, leitores de livros ou espectadores de programas de televisão "compartilham respostas ao programa televisivo, discutem as opiniões uns dos outros e sugerem roteiros para futuros episódios além de contar suas próprias histórias" (2009, p. 163).

Estas novas ferramentas digitais então amplificaram a voz do receptor dentro do processo comunicacional e fizeram por turvar a fronteira entre o leitor/espectador e o autor de conteúdos. O ato da "publicação" deixou de demandar grandes investimentos e esforços coletivos, como os necessários para fazer circular um jornal ou colocar uma rede de rádio ou televisão no ar, e chegou ao alcance de pessoas comuns.

\footnotetext{
"Essas ferramentas comunicacionais já receberam diversos nomes, todos variações do mesmo tema: 'software social', 'mídia social', 'computação social' e assim por diante. Apesar de haver algumas distinções entre esses rótulos, a ideia central é a mesma: estamos vivendo em meio a um notável aumento de nossa capacidade de compartilhar, cooperar uns com os outros, e tomar ações coletivas, tudo isso fora das molduras tradicionais das instituições e das organizações." (SHIRKY, 2008, p. 20)
} 
A colaboração no contexto das mídias digitais, portanto, está profundamente associada à popularização do acesso à Internet, ao aumento da velocidade das conexões, à construção de websites mais sofisticados, capazes de lidar com grandes bancos de dados com baixa latência - tripé do que se convencionou chamar Web 2.0- e também ao desenvolvimento de aparelhos portáteis de registro da realidade, capazes de abastecer estes bancos de dados online com informações do mundo sensível - textos, fotos, sons e vídeos. São os notebooks, celulares, câmeras de fotografia e vídeo, cujos subprodutos (conteúdos digitais) abastecem a Internet, hoje responsável por interligar vários computadores, e, consequentemente, várias pessoas. Essa popularização de aparelhos eletrônicos teve início ainda antes do surgimento da rede mundial de computadores:

\begin{abstract}
"Durante os anos 1980, novas tecnologias transformaram o mundo da mídia. Jornais foram escritos, editados e impressos à distância, permitindo edições simultâneas do mesmo jornal sob medida para várias áreas importantes. (...) Os aparelhos tipo walkman transformaram a seleção pessoal de música em um ambiente de áudio portátil, dando oportunidade às pessoas, em particular aos adolescentes, de construir suas paredes de sons contra o mundo exterior. (...) Os videocassetes explodiram em todo o mundo e tornaram-se em muitos países em desenvolvimento importante alternativa à enfadonha programação da televisão oficial. (...) As pessoas começaram a filmar seus eventos, de férias a comemorações familiares, assim produzindo as próprias imagens, além do álbum fotográfico. (...) Tal prática realmente modificou o fluxo de mão-única das imagens e reintegrou a experiência de vida e a tela." (CASTELLS, 2006, p. 422-423)
\end{abstract}

Simon e Vieira (2008) nos ajudam a fundamentar a relação entre a popularização da Web e a criação deste cenário propício à colaboração. Em seu texto "Rossio não-rival", os autores comparam a rede mundial de computadores às terras utilizadas coletivamente para o pasto na Inglaterra durante a Idade Média, chamadas de "rossios". Os membros dessas comunidades que compartilhavam terras tinham uma série de direitos de uso sobre a propriedade, e essas comunas não tinham um proprietário exclusivo — daí o termo "não-rival", já que os pastos admitiam usos simultâneos que não competiam entre si. Rossio não-rival, portanto, seria um espaço comum que permite usos concomitantes e não-concorrentes. A língua é um exemplo de rossio não-rival, segundo os autores, já que se torna um "espaço comum" de significações utilizado por seus diversos atores sem que 
eles precisem concorrer entre si por seu uso, ou sem que uso por um dos atores do processo de comunicação impeça seu uso simultâneo por outro. A concorrência pelo uso só ocorre quando a língua em si, rossio não-rival, é expressa em um suporte material, seja ele um livro —que é um bem rival, já que normalmente só pode ser lido por uma pessoa ao mesmo tempo- ou até mesmo um simples diálogo — que limita o uso da língua pelo tempo e pela a cadência necessária a uma conversação, sem a qual não haveria compreensão por parte dos atores. Limitações que, para Simon e Vieira (2008), evaporaram com a Internet (2008, p. 20):

\footnotetext{
"Se, no passado, os rossios não-rivais possíveis só podiam ser armazenados em estruturas como a da língua portuguesa ou a de uma biblioteca física (e que, portanto, dependiam profundamente de nossa memória ou de bens rivais, como os exemplares dos livros), a tecnologia digital viabilizou a constituição de rossios não-rivais mais amplos, baratos e eficientes, e que antes eram impraticáveis."
}

A Internet, deste ponto de vista, é um "terreno comunitário" que permite a construção e o consumo não-rival de seus recursos a todos aqueles que têm condições de acessá-la e capacitação técnica para navegar por ela de forma autônoma. Um website pode ser acessado por milhões de pessoas ao mesmo tempo. Um software também pode ser executado por diversos usuários, em diferentes computadores, simultaneamente. A distribuição de arquivos digitais pela rede foi simplificada, barateada e relativamente descentralizada: havendo o acesso à Internet, a distribuição de um arquivo tem custo baixo e igual para qualquer lugar, independentemente de continente ou país. Perde-se a necessidade de grandes estruturas de impressão e distribuição física. E também de grandes estruturas de broadcast, já que os computadores usam redes já estabelecidas as telefônicas- para trocar dados entre si. E com a descentralização da distribuição de conteúdos, consegue-se também baratear e simplificar os processos de colaboração entre os atores de processos criativos. O que, entre outros desenvolvimentos, acarretou na aparição do movimento do software livre: 
"Com o surgimento da Internet, a facilidade de comunicação e distribuição de softwares possibilitou o surgimento de novas formas de trabalho colaborativo. Aliando esse avanço na comunicação ao uso da modularidade (isto é, a possibilidade de divisão do software em componentes desenvolvíveis independentemente) e de integradores automáticos das contribuições individuais, foi possível envolver colaboradores extremamente diversos em torno de uma grande tarefa. (...) Trata-se do movimento do software livre: a construção coletiva de uma ampla gama de softwares de qualidade, em constante atualização e evolução, e -o que talvez seja o mais importante- organizado na forma de um rossio." (SIMON E VIEIRA, 2008, p. 22)

Antes de Simon e Vieira (2008), porém, Yochai Benkler (2006) já compreendia a produção colaborativa na Internet sob uma óptica mais ampla, relacionando o fenômeno à evolução do próprio sistema de produção capitalista, assim como o faz Castells (1999) em relação à Internet. O autor chega a comparar a colaboração ao próprio mercado:

"O termo peer production [produção por pares] caracteriza um conjunto de práticas produtivas comunitárias. Se refere a sistemas de produção que dependem de ação individual de livre escolha e descentralizada, mais que ações atribuídas hierarquicamente. A 'centralização' é uma resposta particular ao problema de fazer o comportamento de muitos agentes individuais aderir a um padrão ou atingir um resultado efetivo. Seu atributo primário é a separação entre o locus de oportunidade de ação e a autoridade que escolhe a ação que o agente tomará. Autoridades governamentais, gerentes empresariais, professores em uma sala de aula, todos ocupam um contexto em que potencialmente muitas vontades individuais poderiam levar à ação, e reduzem o número de pessoas cuja vontade pode afetar o padrão comportamental que os agentes adotarão. A 'descentralização' descreve as condições sob as quais as ações de muitos agentes coadunam e são efetivas, apesar do fato de que elas não apoiam-se sobre a redução do número de pessoas que contam para a ação efetiva direta. (...) O modo mais sutil de 'descentralização', no entanto, é o mercado ideal. Cada agente individual age de acordo com sua vontade. Coerência e eficácia emergem porque os indivíduos sinalizam seus desejos, e planejam seus comportamentos não em cooperação com outros, mas em coordenação, entendendo a vontade dos outros e expressando suas próprias por meio do sistema de preços." (BENKLER, 2006, P. 62)

Segundo Shirky (2008), a indústria da mídia foi uma das que sofreu mais intensamente com o recente colapso nos custos da comunicação. Isso porque, antes do advento da Internet, era difícil mover palavras, imagens e sons do autor ao público.

\footnotetext{
"Em troca por ajudar a resolver este problema, as empresas de mídia acabaram por exercer um controle considerável sobre os canais de comunicação e extrair lucros consideráveis do público. A viabilidade comercial da maioria dos meios de comunicação envolve promover esta solução, então a preservação do problema se tornou um imperativo econômico. Agora, porém, os problemas de produção, reprodução e distribuição são bem menos sérios. (...) A velha barganha do jornal impresso -notícias internacionais entremeadas de horóscopo e anúncios de pizzarias- agora acabou. $\mathrm{O}$ futuro apresentado pela Internet é o da 'amadorização' em massa da publicação e uma mudança de 'Por que publicar isso' para 'Por que não?'. (...) A questão que este processo coloca para a mídia tradicional é: 'O que acontecerá quando os custos de reprodução e distribuição forem embora? $O$ que acontecerá quando não houver mais nada de especial em publicar, porque os usuários poderão fazer isso pro si próprios?"' (SHIRKY, 2008, p. 59-60)
} 
Os usuários de Shirky ou agentes individuais de Benkler são o que a mídia de massa antes chamava de público, antigo receptor passivo. Este personagem nos remete à visão de um ser humano sentado no sofá, ao final de um dia de trabalho, preso ao controle remoto e às imagens que alguns canais de televisão oferecem. Cenário que não desapareceu com o advento da Internet, mas passou a conviver com novas formas de comunicação digital que puseram abaixo as fronteiras entre o consumo de informação e sua produção. O antigo receptor da mídia de massa não encontra mais barreiras institucionais ou tecnológicas da era anterior ao advento da Web para participar de grupos em ambientes midiáticos digitais. "As dificuldades que mantinham afastadas pessoas que poderiam trabalhar em conjunto estão diminuindo, e o número e os tipos de coisas que os grupos podem fazer sem motivações financeiras ou vigilância gerencial está crescendo", diz Shirky (2008, p. 21). Ideia consonante é expressa por Bruns (2005) quando se refere à participação do público no jornalismo e cunha o termo produser, fusão de producer (produtor) e user (usuário) e que traduzimos livremente como "produsuário". Segundo ele, produsuários são "usuários de sites de notícias que se engajam com estes sites em modos de consumo e produção, alternadamente (e frequentemente em ambos os modos, virtualmente ao mesmo tempo)" (BRUNS, 2005, p. 23).

Mas a simples liberdade de publicar textos, sons e vídeos na Internet torna pessoas que faziam parte do "antigo público" jornalistas? Eis a primeira distinção necessária antes de definirmos, por fim, o jornalismo colaborativo. Necessária também para afastar discursos empolgados e pouco críticos em relação ao chamado UGC (user generated content, ou conteúdo gerado pelo usuário) - compreender que nem tudo o que um usuário publica na rede concorre, necessariamente, com a mídia, tampouco com o jornalismo. "Pessoas postando mensagens umas para as outras em pequenos grupos estão se comunicando de forma diferente que pessoas postando mensagens para centenas ou milhares de pessoas lerem. (...) O público não é simplesmente uma grande comunidade; uma comunidade também não é apenas um pequeno público; ela tem uma 
densidade social que os públicos não têm. Blogueiros e usuários de redes sociais operando em pequenos grupos são parte de uma comunidade" que, segundo Shirky (2008, p. 85), pode ser análoga a um grupo de adolescentes conversando ao redor de uma mesa na praça de alimentação de um shopping center. "A maioria do conteúdo gerado pelo usuário não é 'conteúdo', no sentido de ter sido criado para consumo geral. (...) A maior parte do que é criado em um dia são apenas coisas comuns da vida — fofoca, atualizações, pensamentos verbalizados- mas agora isso é feito no mesmo meio em que é publicado material produzido por profissionais", diz o autor.

É preciso compreender, portanto, que é o tipo de narrativa que faz do UGC jornalismo, ficção ou conversa entre amigos, entre tantas modalidades narrativas possíveis nos suportes das linguagens e do meio digital. Exatamente por isso discorremos, no início deste capítulo, sobre algumas das características do discurso jornalístico, os atributos da notícia e os valores que pautam a produção desse tipo de narrativa. A capacidade de diferenciar entre estes diferentes textos é cada vez mais importante, uma vez que:

\footnotetext{
"Agora que nossas tecnologias de comunicação estão mudando, as distinções entre esses padrões de comunicação estão evaporando; o que antes era uma fronteira nítida entre dois estilos de comunicação está se tornando uma transição suave. A maior parte do conteúdo gerado pelo usuário é concebido como comunicação em pequenos grupos, mas uma vez que estamos desacostumados a ver comunicação interpessoal e mídia de difusão misturadas, pensamos que todo mundo está fazendo broadcast. Isso é um erro. Se pudéssemos ouvir os telefonemas de outras pessoas, saberíamos esperar conversinhas, piadas internas e coisas do gênero, mas os telefonemas das pessoas não estão expostos por aí." (SHIRKY, 2008, p.87)
}

Para que haja jornalismo colaborativo, é preciso haver jornalismo e é preciso haver colaboração. Como as fronteiras entre os tipos de narrativas está se diluindo e todas elas convergem para as mesmas plataforma de publicação e consumo na Internet, torna-se indispensável à pesquisa em jornalismo -e cada vez mais ao jornalista e também ao cidadão comum que deseja informar-se nas plataformas digitais- diferenciar entre tipos de discurso para não incorrer em erros como alguns que demonstraremos no capítulo 4 adoção de material de divulgação como jornalismo ou falta de estímulo à real colaboração, 
utilizando material de usuários como simples fonte de informação- e, assim, compreender e assimilar a evolução tecnológica sem, no entanto, deixar sucumbir os princípios que norteiam a prática jornalística e também a prática colaborativa no jornalismo.

Nem toda publicação feita pelo usuário concorre, portanto, com a mídia ou com o jornalismo. Distinção feita, vamos nos concentrar nos conteúdos gerados pelo usuário que se enquadram no jornalismo.

\section{JORNALISMO COLABORATIVO}

De um ponto de vista conceitual, poderíamos dizer que o público já participa do jornalismo, ainda que de forma absolutamente passiva, quando serve como fonte de informação ou como "personagem" em matérias jornalísticas, recurso normalmente utilizado para atribuir credibilidade ao texto. No jornalismo televisivo, por exemplo, uma prática comum é a chamada "enquete" ou "povo fala", definida como uma série de entrevistas, em geral curtas, sobre determinado assunto. Como o próprio nome diz, populares são interpelados aleatoriamente na rua pelo repórter para falar sobre um tema. "Embora careça de qualquer rigor científico que caracterize uma pesquisa de opinião, a enquete pode ser inadvertidamente considerada como tal. Pela edição, as respostas extremamente breves às vezes expõem posições polêmicas ou divertidas quanto ao tema da enquete" (Rezende, 2000, p. 150). De qualquer forma, este tipo de participação mantém jornalista e público em suas funções originais -o primeiro com absoluto controle sobre o que será ou não publicado, o segundo em uma postura meramente reativa ao trabalho do jornalista.

Até mesmo a postura ativa do público diante da mídia não é um fenômeno novo, que tenha surgido com a Internet ou com o jornalismo colaborativo. Harrison e Barthel (2009, p. 165-166) citam estudos sobre formas radicais de mídia que revelam um processo de 
apropriação da mídia pelo público —"historicamente, ativistas de movimentos sociais produziram e distribuíam conteúdos com presença consistente e poderosa, mesmo que esses esforços tenham passado despercebidos pela indústria da mídia de massa". Além disso, "a mídia comunitária refere-se a formas de comunicação pública em escala relativamente menor, como estações locais de TV a cabo [no caso dos EUA], rádios comunitárias ou jornais comunitários, que historicamente serviram a públicos que residem dentro de uma área geográfica específica e de alguma forma restrita."

De qualquer forma, a apropriação da mídia pelo público no sentido da contestação social também mantém emissor e receptor em seus lugares anteriores (modelo de broadcast, Figura 1), enquanto o jornalismo colaborativo propõe a fusão de papéis para a criação de um novo cenário comunicativo.

\section{FIGURA 1}

Modelo de Broadcast

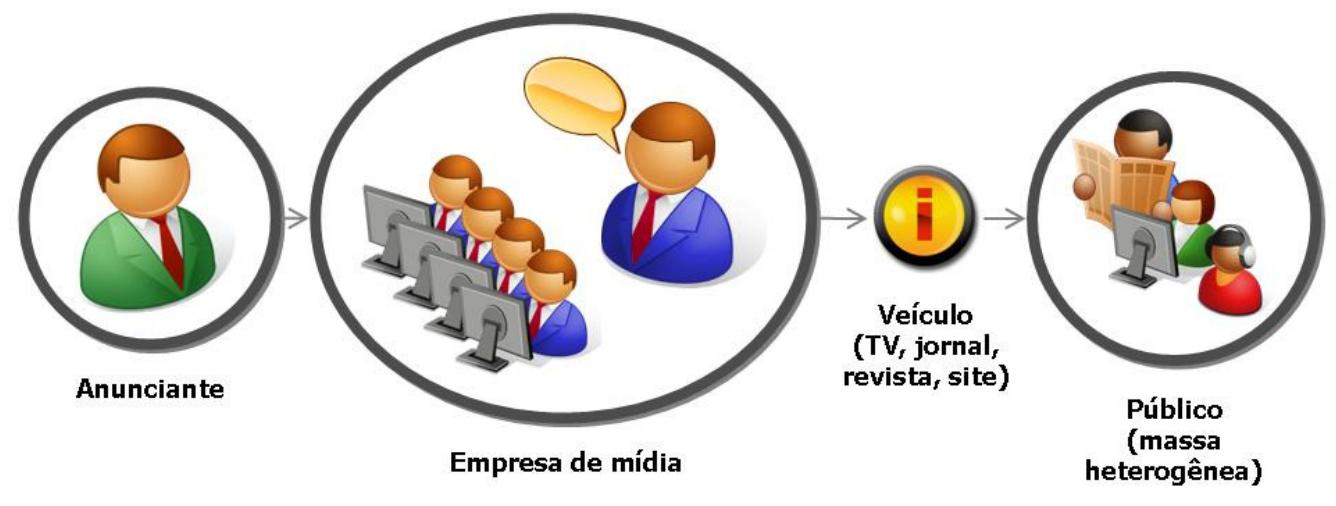

Fonte: Adaptado de BOWMAN; WILLIS, 2003, p. 11

Bowman e Willis (2003, p. 9) definem jornalismo colaborativo como ação de um cidadão ou grupo de cidadãos com um papel ativo no processo de coleta, reportagem, análise e disseminação de notícias e informações. O objetivo dessa participação é prover informações independentes, confiáveis, precisas, abrangentes e relevantes, necessárias à trajetória e ao equilíbrio da democracia. Gillmor (2004, p. 18) nota que o jornalismo 
colaborativo fez emergir uma "conversação pela qual seja possível iluminar uns aos outros. Corrigir nossos erros. Adicionar novos fatos e contextos" ao noticiário.

Note-se a profunda diferença entre, de um lado, acolher o que o público diz como enquete televisiva (o "povo fala"), que fundamenta a visão do jornalista, ou tomar o espaço antes ocupado por um jornalista ligado à uma empresa capitalista para divulgar discursos de oposição; e de outro "iluminar uns aos outros" -a nova postura, então, é compreender a mídia e o jornalismo como um palco de diálogos, e não mais uma via de mão única para divulgação de ideias de um núcleo propagador para uma periferia receptora. Abandona-se o então modelo de broadcast, caracterizado pelo controle das mensagens e dos veículos por parte de uma organização midiática e pelo filtro de conteúdos antes que ele chegue ao público, em favor de um modelo chamado por Bowman e Willis (2003) de intercast, ligado à lógica da mídia social de Shirky (2005), em que os participantes do processo comunicativo são pares e têm a possibilidade de trocar de papéis a qualquer momento. As notícias normalmente não passam por filtros prévios antes de chegar ao público - muitas vezes, ao contrário, chegam à mídia depois de terem repercutido amplamente em ambientes digitais colaborativos.

FIGURA 2

Modelo de Intercast

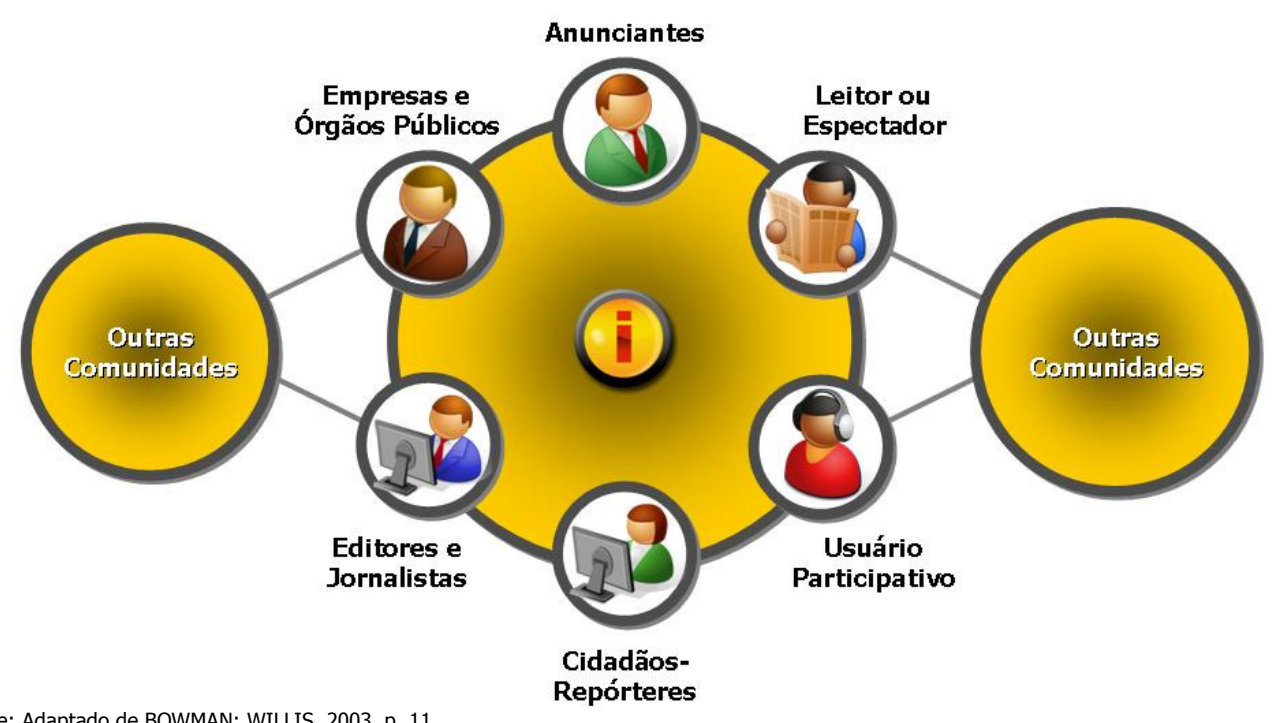


Aliado à facilidade de publicação de informações na Web, o novo modelo de Intercast fez emergir diferentes possibilidades de participação do público na construção do noticiário. Bowman e Willis (2003) e Bruns (2005) enxergam algumas delas. Os primeiros, por exemplo, categorizam o jornalismo colaborativo de acordo com a função que o público exerce diante da mídia. A mais elementar seria o comentário, que nas últimas três décadas, segundo os autores, tomou a forma de fóruns, newsgroups, salas de bate-papo e mensagens instantâneas na Web. Em seguida viria o processo de filtro e edição, que pode ser simplesmente passivo -o público acessa notícias, e o site cria visualizações como as notícias mais lidas - ou ativo - como o processo de votação de notícias, que gera home pages temáticas com hierarquias dinâmicas de notícias mais relevantes, como o Digg.com (http://digg.com). Outra forma de participação seria a checagem de fatos, processo comum em fóruns e blogs, em que normalmente uma discussão começa a partir de um link para uma matéria, seguido por questionamentos de alguns dados do material original, que em posts seguintes são validados (ou não) por outros usuários em comentários ao post inicial. Este processo é comum em sites como o Slashdot (http://slashdot.org). O próximo passo seria o registro flagrante de um acontecimento -o testemunho de um acidente, de um crime, um evento artístico. Blogs e sites que hospedam fotos e vídeos, como Flickr (http://flickr.com) e Youtube (http://youtube.com) tornaram-se repositórios desse tipo de conteúdo, e muito frequentemente abastecem a mídia tradicional com imagens e relatos - como no caso do tiroteio na Faculdade de Tecnologia da Virgínia (EUA), em $2007^{19}$, e no acidente de avião da Turkish Airlines em Amsterdam, em $2009^{20}$, em que imagens publicadas na Web chegaram ao público antes que as produzidas por redes de notícias como a CNN.

\footnotetext{
${ }^{19}$ Virginia Tech School Shooting Caught on Camera phone. Disponível em: <http://www.youtube.com/watch?v=iVPx6oWmtKY>. Acesso em: 16 jun. 2010

20 Twitter first to publish dramatic crash pictures. Disponível em: <http://edition.cnn.com/2009/WORLD/europe/02/25/ twitter.amsterdam.plane.crash/index.html>. Acesso em: 16 jun. 2010
} 
Entre as formas mais engajadas de participação do público no noticiário, Bowman e Willis (2003) descrevem a complementação da apuração de informação jornalística, que pode acontecer em sites independentes ou mesmo em canais específicos da grande imprensa; e a produção open source de notícias, com a revisão e complementação por pares, modelo existente no WikiNotícias (http://pt.wikinews.org) e no OverMundo (www.overmundo.com.br), por exemplo. Os autores também citam modelos de transmissão ao vivo de áudio e vídeo, publicidade colaborativa e gerenciamento de conhecimento.

Se pudéssemos então estabelecer graus de participação do antigo leitor na construção do noticiário, de acordo com Bowman e Willis, teríamos a seguinte escala:

\section{FIGURA 3}

Categorias de Jornalismo Colaborativo segundo a Participação do Público

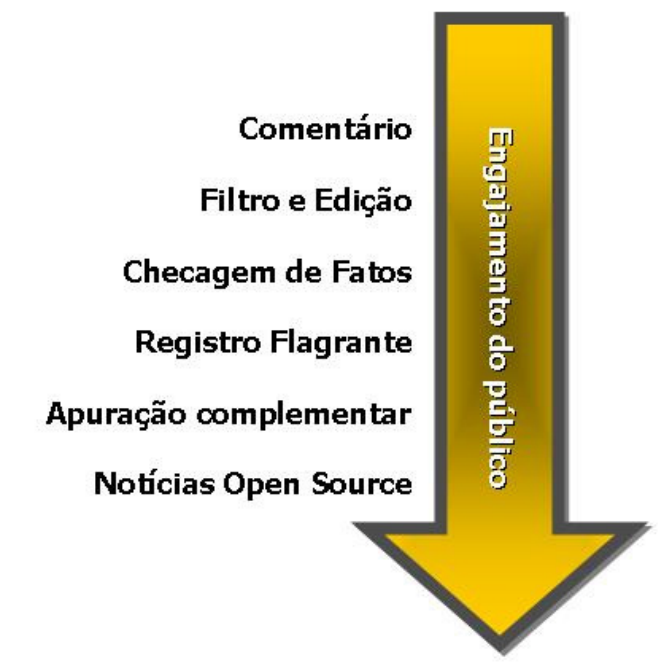

Fonte: Adaptado de BOWMAN; WILLIS (2003)

Bruns (2005) também cria diversas taxonomias para tentar compreender os diferentes níveis de participação do público no noticiário diante dos novos recursos colaborativos da Internet. Ele analisa Slashdot (http://slashdot.org), Indymedia (http://indymedia.org), Wikipedia (http://wikipedia.org), MediaChannel (http://mediachannel.org) e Kuro5hin (http://kuro5hin.org) para definir critérios de análise acerca dos modelos de colaboração 
adotados por veículos de comunicação online. Segundo ele, para descobrir o nível de participação que um site jornalístico permite é necessário avaliar (2005, 124):

1) Participação na entrada da informação: o quanto o público consegue contribuir com material para o processo de construção das notícias no estágio de apuração e coleta de material;

2) Participação na saída da informação: o quanto o público consegue influenciar o conteúdo que será publicado, seja por processos de filtro ou mesmo edição;

3) Participação na resposta à informação: o quanto o público pode comentar, relacionar, filtrar ou editar conteúdos que já foram publicados;

4) Centralização do gatewatching: quanto o site foca na publicação de material noticioso original ou no fornecimento de comentários sobre itens previamente selecionados;

5) Papéis fixos ou móveis: o quanto papéis específicos (editor, jornalista, usuário, leitor) permanecem intocados no processo de produção da notícia;

6) Mobilidade de pares: a habilidade dos participantes se elevarem ou caírem dependendo da freqüência e da qualidade de sua colaboração ao site;

7) Centralização da organização: a formação institucional e tecnológica do site, de servidores e equipes centralizadas até redes descentralizadas.

Com base nestes critérios e na análise dos sites mencionados, Bruns desenha dois níveis de colaboração para o jornalismo na Internet. O primeiro e mais básico seria o que ele chama de Noticiário fechado, adotado por sites tradicionais como CNN (http://cnn.com) ou The New York Times (http://nytimes.com) -veículos que aceitam produção de conteúdo apenas por suas afiliadas ou repórteres, e conduzem um processo editorial completamente fechado, distante dos olhos do público; a participação do público 
inexiste nos estágios de entrada e saída de informação, e mesmo no estágio de resposta, a participação do público com comentários e cartas é extremamente controlada. O papel do editor e do jornalista permanece central na construção do noticiário, enquanto o público é visto como mero receptor, aproximando o noticiário fechado do modelo clássico da comunicação (figura 1).

Bruns (2005) usa a metáfora dos portões quando fala sobre este papel centralizador exercido pelo jornalismo tradicional. É o chamado gatekeeping-regime de controle sobre os conteúdos que emergem do processo de produção jornalística em meios impressos ou eletrônicos. Quem controla este processo -jornalistas, editores ou donos dos veículos de comunicação, chamados gatekeepers - "controla os portões pelos quais o conteúdo chega até o público" (2005, p. 11). 0 autor define três principais "portões" do processo jornalístico tradicional:

FIGURA 4

Processo Jornalístico Tradicional

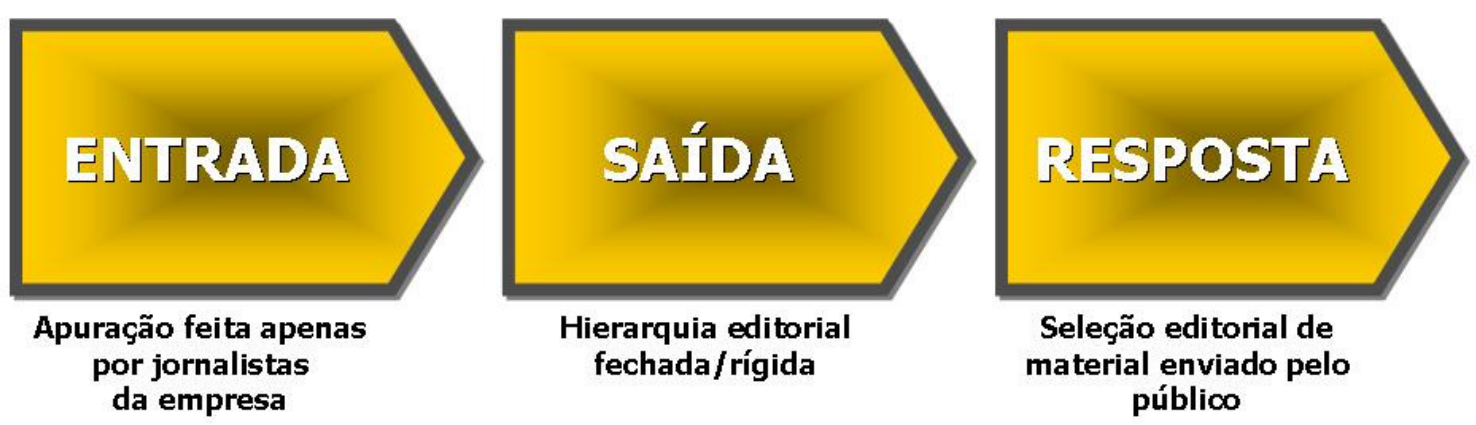

Fonte: BRUNS, 2005, p. 11

O jornalista ou editor seria então o "segurança", o "guarda" destes três portões, aquele que controla a entrada e a saída de informações para o público, e a entrada do próprio público no mundo da informação, via canais de resposta. Realidade que desmoronou com a popularização da Internet diante da realidade da mídia de massa: 


\begin{abstract}
"As mídias digitais como a World Wide Web funcionam de acordo com modelos diferentes dos da mídia impressa ou mesmo da mídia eletrônica de transmissão em massa, e como resultado todos os três portões mantidos pelas organizações noticiosas podem agora ser transpostos. $\mathrm{O}$ armazenamento e a transmissão digitais expandiram maciçamente o espaço e o tempo disponíveis ao conteúdo midiático, a ponto de tornar irrelevantes ao produtos de conteúdo as restrições de largura de banda [para transmissão de dados], enquanto ao mesmo tempo o maior acesso aos meios de produção midiática permitiram a mais usuários tornarem-se produtores e publishers de conteúdo." (BRUNS, $2005,13)$
\end{abstract}

Diante desta realidade, a figura do "guarda do portão" começa a perder relevância. 0 gatekeeper, aquele que mapeia a informação disponível na tentativa de limitar a quantidade de dados que flui pelos portões entre mídia e público, de forma a atender às necessidades do público e da organização noticiosa para qual ele trabalha, cede espaço ao bibliotecário - que não produz e publica informações ele mesmo, mas adquire o maior conhecimento possível sobre o material que transita pelos "portões da informação" de forma a ser capaz de apontar aos usuários da biblioteca as direções corretas no mar de informação e conhecimento que dominam. A figura do bibliotecário leva Bruns a cunhar o termo gatewatcher para definir veículos, usuários ou comunidades que "observam os portões de saída dos veículos tradicionais de mídia e outras fontes de forma a identificar materiais importantes assim que eles são disponibilizados." (BRUNS, 2005, 17).

A figura do bibliotecário nos leva ao segundo nível de participação proposto pelo autor, o do Noticiário colaborativo (BRUNS, 2005, p. 126), que englobaria em si diversas matizes de ação do usuário no processo jornalístico. O primeiro nível seria o que ele chama de Gatewatching fechado, e cujos representantes seriam os sites que observam a mídia Bruns cita o MediaChannel (http://mediachannel.org), espécie de observatório da imprensa que avalia a qualidade das publicações noticiosas, mas só permite a publicação de conteúdo por afiliados, sejam eles jornalistas ou representantes da sociedade civil. O nível seguinte seria o do Gatewatching supervisionado, com o Slashdot.org (http://slashdot.org) como exemplo -o site permite um alto grau de participação dos usuários no envio de informações, mas nem todas elas são publicadas, já que os editores do site ainda julgam que conteúdos podem ser destacados. De qualquer forma, os 
usuários também têm ampla participação no processo de resposta, já que podem comentar livremente os materiais selecionados para publicação pelos editores. O terceiro nível seria o do Noticiário Aberto Assistido pelo Editor, em que Bruns enquadra o popular site sul-coreano OhMyNews (http://english.ohmynews.com), ícone do jornalismo colaborativo, com uma equipe editorial que seleciona, edita e coordena o trabalho de milhares de cidadãos-repórteres espalhados pelo mundo. Por fim, o autor cita o nível do Noticiário Aberto, em que a figura do editor de conteúdo no sentido tradicional é eliminada, e os portões de entrada, saída e resposta da informação são completamente geridos pelos produsuários. A única figura que persiste, segundo Bruns (2005, p. 130), é a do operador técnico do site, normalmente necessário nas estruturas de publicação Web. Como exemplo, Bruns cita o Indymedia (http://indymedia.org), em diversas instâncias internacionais -dentre as quais podemos incluir a brasileira, CMI Brasil (http://midiaindependente.org), em que qualquer pessoa com acesso à Internet pode publicar matérias.

TABELA 5

Níveis de Participação em Publicações Colaborativas

\begin{tabular}{|c|c|c|}
\hline \multicolumn{2}{|c|}{ Níveis de participação } & Exemplo \\
\hline $\begin{array}{c}\text { Noticiário fechado } \\
\text { (Gatekeeping) }\end{array}$ & Comentários moderados & The New York Times \\
\hline \multirow{3}{*}{$\begin{array}{c}\text { Noticiário colaborativo } \\
\text { (Gatewatching) }\end{array}$} & Gatewatching fechado & MediaChannel \\
\cline { 2 - 4 } & Noticiário Aberto Assistido pelo \\
Editor & Slashdot.org \\
\cline { 2 - 4 } & Noticiário Aberto & OhMyNews \\
\cline { 2 - 3 } & & Indymedia \\
\hline
\end{tabular}


Bruns (2005), no entanto, não traça diferenças, dentro do noticiário colaborativo, entre a mera citação de informações produzidas por terceiros e a participação ativa do público na construção de conteúdo. O primeiro, apesar de ter papel ativo, permanece apenas como editor/seletor de informações; o segundo tem papel ativo na construção do noticiário. Na taxonomia de Bruns, é como se, no primeiro nível de colaboração -o noticiário fechado- houvesse o antigo leitor; e no segundo nível, o "usuário" de Internet. Bruns não usa seu próprio conceito de produsuário para tentar distinguir níveis de colaboração, o que nos deixa a dúvida: todo usuário de Internet que colabora pode ser chamado de cidadão-repórter? E se as funções do público mudam conforme o nível de participação cresce, o que acontece com as funções do jornalista?

Ao abordar o novo processo de autoria digital, Murray (2003) compara os livros ou narrativas tradicionais lineares a jogos de computador ou mesmo RPGs (role-playing games) —são todos narrativas, como o jornalismo também o é, mas com níveis diferentes de participação do leitor. Para as narrativas digitais, a autora prefere o termo interator, destacando assim os processos interativos que a Internet e o computador possibilitaram diante das narrativas tradicionais. O conceito é bastante semelhante ao do produsuário de Bruns (2005) e também é abordado por Shirky (2006) quando fala dos processos de produção colaborativa de conteúdo.

Segundo Murray (2003), as narrativas digitais diferem das tradicionais pela criação de cenários, e não apenas de histórias lineares. Cenários que os interatores devem explorar para descobrir histórias possíveis — quando o autor expande a história para incluir nela múltiplas possibilidades, o leitor adquire um papel mais ativo:

\footnotetext{
"A forma mais ativa de engajamento do público é a dos clubes de Jogos de Representação - RPGs. (...) Os jogos de representação são teatrais de um modo não-convencional, mas emocionante. Os jogadores são, ao mesmo tempo, atores e espectadores uns para os outros, e os eventos que eles encenam freqüentemente possuem o imediatismo das experiências pessoais." (2003, p. 53)
} 
Para propor uma nova taxonomia e tentar localizar o cidadão-repórter nos níveis de participação propostos tanto por Bowman e Willis (2003) como por Bruns (2005), lançamos mão do conceito de interator cunhado por Murray (2003) como um usuário que exerce "um papel ativo no processo de coleta, reportagem, análise e disseminação de notícias e informações" (BOWMAN; WILLIS, 2003, p. 9) -vamos considerar o interator, portanto, como verdadeiro cidadão-repórter. Para acolher o papel do antigo leitor como editor ou selecionador de informações, utilizaremos o conceito de usuário, amplamente utilizado na literatura dos Internet studies para diferenciar o consumidor de informação em ambientes digitais -e, portanto, interativos - do consumidor de informação analógica, que consideraremos como leitor. Com a fusão de conceitos dos autores, propomos, assim, possíveis níveis de participação ou engajamento do público na construção do noticiário:

TABELA 6

Níveis de Participação vs. Funções do Público no Noticiário Colaborativo

\begin{tabular}{|c|c|c|c|}
\hline Função do público & $\begin{array}{l}\text { Níveis de Participação } \\
\text { Bowman e Willis (2003) }\end{array}$ & $\begin{array}{l}\text { Níveis de Participação } \\
\text { Bruns (2005) }\end{array}$ & Exemplos \\
\hline Leitor & Comentário & $\begin{array}{l}\text { Noticiário fechado } \\
\text { (Gatekeeping) }\end{array}$ & The New York Times \\
\hline \multirow{2}{*}{ Usuário } & \multirow{2}{*}{ Filtro e Edição } & Gatewatching fechado & MediaChannel \\
\hline & & $\begin{array}{l}\text { Gatewatching } \\
\text { supervisionado }\end{array}$ & Slashdot.org \\
\hline \multirow{4}{*}{ Interator } & Registro Flagrante & \multirow{3}{*}{$\begin{array}{l}\text { Noticiário Aberto Assistido } \\
\text { pelo Editor }\end{array}$} & \multirow{3}{*}{$\begin{array}{l}\text { VC no G1 } \\
\text { VC Repórter } \\
\text { OhMyNews }\end{array}$} \\
\hline & Checagem de Fatos & & \\
\hline & Apuração complementar & & \\
\hline & Notícias Open Source & Noticiário Aberto & Indymedia \\
\hline
\end{tabular}


A diferenciação interessa a nosso quadro teórico por fundamentar as conclusões que o estudo propõe, quando procura demonstrar que as atividades de UGC (User Generated Content) dos grandes portais de mídia brasileiros, apesar de orquestradas por editores e jornalistas, não engajam o público nas atividades de pesquisa e reportagem, como veremos adiante. A constatação nos levou a cunhar o conceito de "cidadão-fonte", aquele que apenas abastece o noticiário de veículos de comunicação já existentes com matériaprima bruta, normalmente simples flagrantes da realidade, para um trabalho jornalístico posterior de apuração e complementação de dados. Consideramos também que o termo "cidadão-fonte" é mais adequado ao tipo de participante destes ambientes de mídia digital do que "cidadão-repórter", já que o significado de reportagem só pode ser atribuído ao texto que foi produzido pelo jornalista a partir do mote que a ele é conferido pelo usuário/interator, como veremos no próximo capítulo.

Estabelecidas as bases conceituais, nossa intenção, agora, será analisar o noticiário colaborativo de alguns dos principais portais da Internet brasileira para compreender em que grau adotam os princípios do jornalismo, da colaboração e, por fim, do jornalismo colaborativo.

Internet não é sinônimo, no entanto, de mídia comunitária ou radical —segundo Bruns (2008, p. 27), a presença e a popularidade de veículos tradicionais de comunicação na rede claramente põe em xeque a visão utópica de que a rede é um meio libertário e igualitário, e não só pela influência comercial que exercem, mas pela natureza da participação que agregam. Também é útil compreender que o surgimento de conteúdos a partir do público não necessariamente torna o noticiário mais completo. Segundo o autor, uma cobertura multifacetada de um evento depende, em primeiro lugar, da ação real dos usuários, mas também de quais usuários participam: uma cobertura abrangente, portanto, depende da participação de usuários com várias perspectivas sobre um fato. 


\section{METODOLOGIA}

O jornalismo colaborativo é um fenômeno recente, que emergiu na primeira década do século 21. A prática pode ser considerada fruto do avanço tecnológico dos anos 1990, que difundiu o uso de computadores em rede, câmeras fotográficas e de vídeo digital e outras tecnologias de registro da realidade. Todo este avanço tecnológico traz o tema para o campo da comunicação, que é fundado como tal a partir do desenvolvimento da eletricidade como base dos meios de transmissão e distribuição de informação, durante a última metade do século XIX, segundo Jensen (2008). Até a invenção e a adoção do telégrafo, em meados do século XIX, o transporte e a transmissão de mensagens eram inseparáveis, já que qualquer troca de informação dependia de presença física. A telegrafia foi realmente uma revolução. Porém, se a comunicação analógica progrediu com o rádio e a televisão, fazendo o ser humano abstrair o espaço como fator limitante para seus sentidos, a comunicação digital dispensou também o tempo, fazendo da assincronia um vocábulo constante na troca de informações no início do século XXI. O que reforça a necessidade de rever os conceitos fundadores da comunicação, que, segundo Jensen (2008, p. 32):

"(...) se voltam para processos básicos em que a realidade social é interpretada e reinterpretada no cotidiano, na conversa diária e nas instituições especializadas, das escolas às novas mídias. Segundo, como um campo, a pesquisa em comunicação tem sido, a partir da articulação do século XIX de uma categoria denominada «comunicação», uma reação ao crescimento de um setor social de instituições dedicadas à informação e comunicação, as quais Beniger (1986) se refere como revolução do controle, que foi concluída no final dos anos 30 na alvorada da pesquisa moderna em comunicação. (...) Terceiro, as rápidas transformações das práticas comunicativas na sociedade do século XX e 0 vantajoso sucesso das tradições de pesquisas individuais que os explicam, levaram o campo a se tornar cada vez mais interdisciplinar, observando a comunicação por meio de diferentes perspectivas das ciências humanas, sociais e, em certo grau, das ciências naturais. Assim, a dupla hermenêutica da pesquisa em comunicação se desdobra simultaneamente no interior do campo acadêmico e em seu vínculo com o campo empírico de estudo." 
Em paralelo à consolidação das novas tecnologias de comunicação, consolidava-se também na transição de milênio a sociedade pós-moderna, que passou a questionar, por meio de diversas expressões culturais — seja pela arte, seja pela própria ciência-, as representações unificadas do mundo. A colaboração online pode ser tida, nesse contexto, como uma das expressões da pós-modernidade no âmbito da comunicação em geral, e do jornalismo em particular, partindo do princípio de que qualquer cidadão pode ser um repórter em potencial e contribuir para o cenário midiático, segundo Gillmor (2004), com seu testemunho ou até mesmo seu trabalho de apuração sobre fatos com os quais tem proximidade, seja física ou conceitual. Foi o caráter recente do jornalismo colaborativo, associado a este potencial de democratização da mídia, tornando suas vozes mais plurais, que fizeram do tema algo atraente para nosso estudo.

\section{OBJETO, PROBLEMA, JUSTIFICATIVA}

Os primeiros sites colaborativos com foco jornalístico surgiram na Internet no início dos anos 2000 nos EUA e na Ásia. No Brasil, o fenômeno eclodiu quase ao mesmo tempo, porém de forma mais tímida. Os primeiros sites de jornalismo colaborativo foram iniciativas independentes, como o Centro de Mídia Independente (www.midiaindependente.org), braço brasileiro do site colaborativo Indymedia), ou o site cultural Overmundo (www.overmundo.com.br), que surgiu em 2005 com a missão de divulgar informações culturais além do circuito da grande mídia, com o apoio da Lei Rouanet (lei federal de incentivo à cultura). Outras iniciativas incluem o Wikinotícias (http://pt.wikinews.org), espaço da Wikipedia para a publicação de notícias colaborativas, que entre sua fundação em 2005 e maio de 2010 possuía pouco mais de 6.100 notícias publicadas e apenas 26 colaboradores ativos ${ }^{21} ; 0$ Jornal de Debates (www.

\footnotetext{
${ }^{21}$ Wikinotícias. Estatísticas. Disponível em: http://pt.wikinews.org/wiki/Especial:Estat\%C3\%ADsticas. Acesso em 26 mai. 2010.
} 
jornaldedebates.com.br), que funciona mais como repositório de opiniões e artigos que espaço de cobertura jornalística; o LinkK (www.linkk.com.br), espécie de Digg — central onde os usuários postam links, que ganham relevância e destaque em páginas temáticas quanto mais são postados ou votados pelos leitores- e o BrasilWiki (www.brasilwiki.com.br), associado ao provedor Pop, que possui atualizações diárias e perfis dos "wikirepórteres", mas cujo conteúdo varia entre a reprodução de material publicado por outros veículos, textos opinativos e até auto-biografias ou poemas.

Nenhum destes sites colaborativos, no entanto, ganhou peso jornalístico semelhante ao do OhMyNews na Coreia do Sul. No cenário brasileiro, continuam a dominar em audiência os sites informativos ligados aos grandes portais, centralizadores de tráfego da rede no país, como UOL, iG, Terra, Globo.com e Abril, segundo dados da consultoria norte-americana Netratings distribuídos no Brasil pelo Ibope. No levantamento, os sites independentes de jornalismo colaborativo não chegam a ter audiência suficiente para serem listados sequer entre os cem maiores tráfegos da Web brasileira.

TABELA 7

Top 10 Search Engines/Portals And Communities, Abr. 2010

\begin{tabular}{ccc}
\hline Marca/Canal & $\begin{array}{c}\text { Audiência Única (em mil) } \\
\text { (número de visitantes) }\end{array}$ & $\begin{array}{c}\text { Page Views totais (em mil) } \\
\text { (número de visitas) }\end{array}$ \\
\hline Google & 33.807 & 10.523 .849 \\
\hline MSN/Windows Live/Bing & 31.729 & 5.288 .590 \\
\hline UOL & 27.017 & 3.766 .658 \\
\hline Orkut & 26.501 & 13.904 .795 \\
\hline Terra & 24.080 & 2.121 .550 \\
\hline Globo.com & 23.187 & 2.790 .135 \\
\hline iG & 21.176 & 1.611 .305 \\
\hline Yahoo! & 20.267 & 2.180 .027 \\
\hline Blogger & 19.818 & 762.880 \\
\hline Abril & 13.769 & 413.360 \\
\hline Fonte: Ibope//Netratings, Standard Metrics. Disponivel em <http://www.nielsen-online.com>. Acesso em 26 mai. 2010
\end{tabular}

Cinco anos depois da aparição do fenômeno sul-coreano OhMyNews e também atrasados em relação às iniciativas independentes nacionais, alguns dos chamados "portais" brasileiros — grandes concentradores de audiência no país- decidiram lançar canais de foco jornalístico que permitiam ao leitor enviar seus textos, fotos e vídeos para 
contribuir com o noticiário. Alguns exemplos são o Minha Notícia, do iG (http://minhanoticia.ig.com.br); o VC no G1, da Globo.com (http://g1.globo.com/vc-nog1); e o VC Repórter, do Terra (http://noticias.terra.com.br/vcreporter). Nosso trabalho teve maior foco nos dois últimos, por razões metodológicas que explicitaremos adiante.

globo.com noticias esportes entretenimento vídeos

Q e-mail central globo.com assine já todos os sites

\section{G1 $V C$ noG fivo}

Brasil Mundo | Economia Política | Esporte |Crime Carros |Emprego Educação Saúde | Tech |Bizarro Pop\&Arte RJ SP | Telejornais |África do Sul 2010

\section{Teatro Municipal do Rio recebe últimos retoques}

Espaço reabre na quinta-feira (27) Internauta registra limpeza do prédio

- PARTICIPE DO VC NO G1

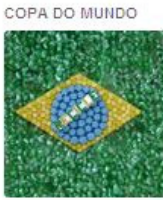

Zona Leste de São Paulo usa reciclagem em decoração

Moradores da Mooca fazem arte com garrafas PET

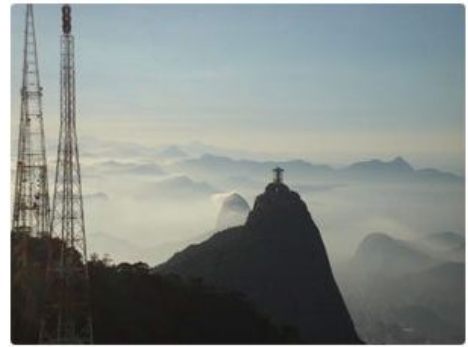

PAISAGEM

Nevoeiro proporciona bela imagem no Rio de Janeiro

participe do vc no g1 "

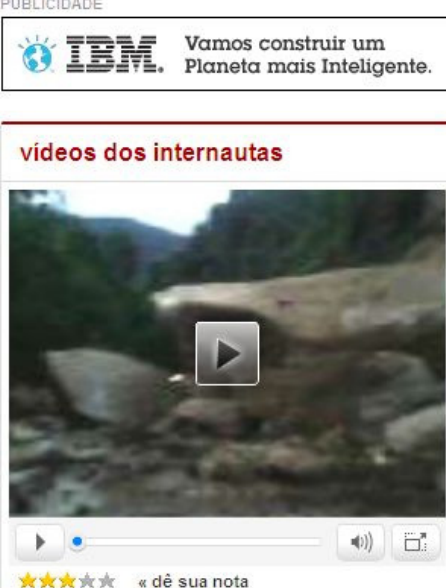

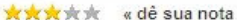

VC no G1 (http://g1.globo.com/vc-no-g1), da Globo.com

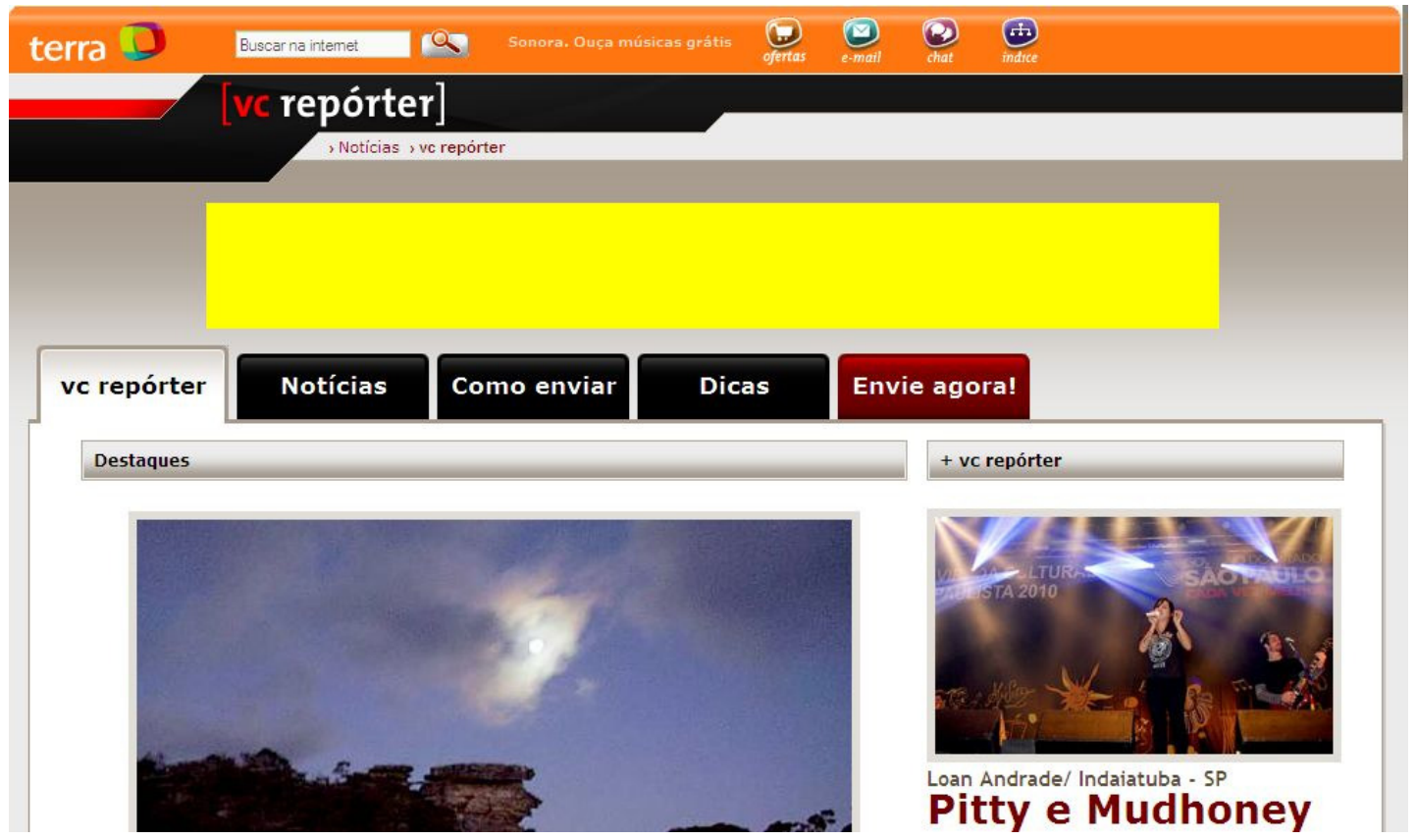

VC Repórter, do Terra (http://noticias.terra.com.br/vcreporter) 
Diante de um cenário independente sem nenhum site tão representativo quanto o sulcoreano OhMyNews (www.ohmynews.com) ou os norte-americanos Digg (www.digg.com) ou Slashdot (www.slashdot.org) e do maior foco dos estudos brasileiros sobre iniciativas internacionais, esta pesquisa buscou debruçar-se sobre o jornalismo colaborativo empreendido pelos portais, grandes concentradores de audiência no país -e, portanto, potenciais difusores do fenômeno do jornalismo colaborativo. A partir de uma avaliação preliminar de nosso objeto, surgiram então algumas indagações que nortearam o desenvolvimento desta dissertação: como ocorre a participação, a colaboração e o diálogo nestes noticiários colaborativos? Qual a aderência dos grandes portais ao conceito de jornalismo colaborativo, que prevê a emergência de conteúdos a partir do público, subvertendo o sentido clássico da comunicação emissor-receptor?

\section{OBJETIVOS E HIPÓTESES}

Questões como estas nos levaram, em um primeiro momento, a debruçar-nos sobre a literatura existente acerca do jornalismo, do jornalismo colaborativo e das mídias sociais, de forma a compreender os modelos existentes e procurar definir níveis de colaboração e participação em rede para o jornalismo. A partir destas definições preliminares, objetivo primeiro de nosso trabalho, tratamos então de analisar o produto final dos grandes portais brasileiros na área de colaboração jornalística para tentar responder às questões que emergiram após o primeiro olhar sobre o objeto. Nesta fase, realizamos um levantamento exploratório do noticiário colaborativo de Minha Notícia (iG), VC no G1 (Globo.com) e VC Repórter (Terra), em paralelo à revisão bibliográfica inicial citada, de forma a empreender uma análise de conteúdo sobre o jornalismo colaborativo dos grandes portais, detalhada mais adiante junto aos procedimentos metodológicos.

Esta primeira fase da pesquisa foi suficiente para constatar que os grandes veículos de comunicação online do país adotaram a colaboração de forma pouco abrangente, 
superficial em relação a iniciativas internacionais como o site colaborativo independente sul-coreano OhMyNews, em que o público é chamado a produzir conteúdo, ou mesmo em sites como o Digg ou o Slashdot, em que o público apenas cita conteúdos por meio de links, ajudando também a editar as "capas" de cada seção ao votar nos conteúdos que julga mais pertinentes, conforme o estudo de Bruns (2005). Podemos inclusive inferir que os portais apenas abarcaram a participação do público, sem ainda deixá-lo colaborar com a construção da notícia -o internauta brasileiro que participa destes serviços interativos age mais como fonte de informação que como cidadão-repórter, engajado na construção do noticiário. Apresentamos os resultados desta primeira fase no próximo capítulo.

Elevada ao status de hipótese, esta constatação, no entanto, deveria ser discutida mais profundamente. Por que redes sociais como o Orkut são tão populares no Brasil — com mais que o triplo de tráfego que o UOL, o maior portal de Internet do país, segundo o Ibope ${ }^{22}$-, mas o jornalismo colaborativo nem tanto? O que os grandes veículos de comunicação online do país enxergam como jornalismo colaborativo? Como a prática contribui para seu noticiário? Como ocorre a integração com o (antigo) público?

A partir dos novos problemas levantados, optamos por realizar uma segunda etapa de pesquisa e entrevistar jornalistas diretamente ligados à produção do noticiário colaborativo dos principais portais brasileiros, além de editores e diretores de redação destes websites. Além de profissionais do G1 e do Terra, sites que participaram efetivamente da análise inicial de dados, conversamos também com representantes do UOL e do iG, além de figuras ligadas ao jornalismo online e à Internet no Brasil, para tentar entender melhor a opção dos portais e o distanciamento que ainda possuem em relação ao conceito de jornalismo colaborativo emergente fora do Brasil.

\section{PROCEDIMENTOS METODOLÓGICOS}

\footnotetext{
${ }^{22}$ Ibope//Netratings, Standard Metrics. Disponível em <http://www.nielsen-online.com>. Acesso em 26 mai. 2010.
} 
O primeiro passo para atingir os objetivos delineados pela pesquisa foi empreender uma revisão bibliográfica sobre pós-modernidade, sociedade em rede, teorias da comunicação e Internet Studies, desenvolvida no capítulo 1, em busca de situar 0 jornalismo colaborativo em um contexto sócio-cultural mais amplo. Em seguida, buscamos no capítulo 2 autores que nos auxiliassem a fundamentar tanto o jornalismo em si, suas práticas e princípios, quanto o jornalismo colaborativo, de forma a contrastar a produção colaborativa do noticiário dos grandes portais a princípios teóricos de ambos os campos do conhecimento. Segundo Fernandes e Gomes (2003, p. 6):

\begin{abstract}
"A pesquisa bibliográfica é, sem dúvida, uma das fontes mais importantes de pesquisa e constitui etapa prévia a ser feita em um processo de pesquisa, seja qual for o problema em questão. Isto se deve ao fato de que é absolutamente necessário um conhecimento prévio do estágio em que se encontra um assunto, antes de iniciar-se qualquer estudo, para não correr o risco de se pesquisar um tema que já foi amplamente pesquisado."
\end{abstract}

A partir desta literatura, estruturamos um estudo exploratório de campo para embasar os pressupostos iniciais e, posteriormente, ampliar nosso espectro de pesquisa. Para Fernandes e Gomes (2003, p. 6), a pesquisa exploratória "é adequada para casos em que ainda não apresentem um sistema de teorias e conhecimentos desenvolvidos [como o jornalismo colaborativo]. Nesse caso é necessário desencadear um processo de investigação que identifique a natureza do fenômeno e aponte as características essenciais das variáveis que deseja-se estudar". Os autores ainda estendem as vantagens desse tipo de método diante de nosso objeto ao lançarem mão de Lakatos e Marconi (1985 apud. FERNANDES E GOMES, 2003, p. 6), para quem o estudo exploratório ajuda a "desenvolver hipóteses, aumentar a familiaridade do pesquisador com um ambiente, fato ou fenômeno para a realização de uma pesquisa futura mais precisa ou modificar e clarificar conceitos". 
Considerando o recorte que privilegia os portais brasileiros, iniciamos o trabalho com a definição da amostragem pelos seguintes critérios combinados: audiência ${ }^{23} \mathrm{e}$ disponibilização de área específica para a manifestação do usuário em formato de UGC (User Generated Contet). Deste recorte, chegamos à seguinte seleção: portal Terra, com a área VC Repórter, e portal Globo.com, com a área VC no G1.

Justificamos a exclusão, nesta etapa da pesquisa, dos portais UOL, iG e Abril, a partir da existência (ou não) de áreas de jornalismo colaborativo coerentes às definições dos autores referenciados. Para tanto lançamos mão do critério de homogeneidade postulado por Fonseca Júnior (2005 apud. DUARTE e BARROS, 2005, p. 293) como fundamental para a constituição do corpus, ou conjunto de documentos a serem submetidos a uma análise de conteúdo:

"(...) os documentos obtidos devem ser da mesma natureza, do mesmo gênero ou se reportarem ao mesmo assunto. Cinema, publicidade e jornalismo, por exemplo, são gêneros diferentes de comunicação que se prestam à análise de conteúdo. Mas o corpus não pode incluir, simultaneamente, filmes, anúncios e notícias. Além disso, dentro de uma mesma natureza de documentos pode haver subdivisões, como os gêneros cinematográficos (romance, aventura, comédia, mistério etc.) e os gêneros jornalísticos (notícias, editoriais, artigos, entrevistas etc.), exigindo também critérios diferenciados para serem analisados, de forma a respeitar sua homogeneidade."

Segundo este critério, portanto, apesar de ser o portal de maior audiência no país, o UOL permaneceu de fora da amostra por não possuir um produto consolidado de jornalismo colaborativo, e adotar a participação do usuário de maneira esparsa e inconstante em seu noticiário.

O iG, por outro lado, possui um site de jornalismo colaborativo, o Minha Notícia. Ele inicialmente fez parte da amostra, porém, após uma semana de coleta de dados, foi removido do estudo por incongruências entre o material publicado, as próprias políticas do site e os objetivos do estudo.

\footnotetext{
${ }^{23}$ Conforme Tabela 7, " Top 10 Search Engines/Portals And Communities, Abr. 2010", apresentada na página 47
} 


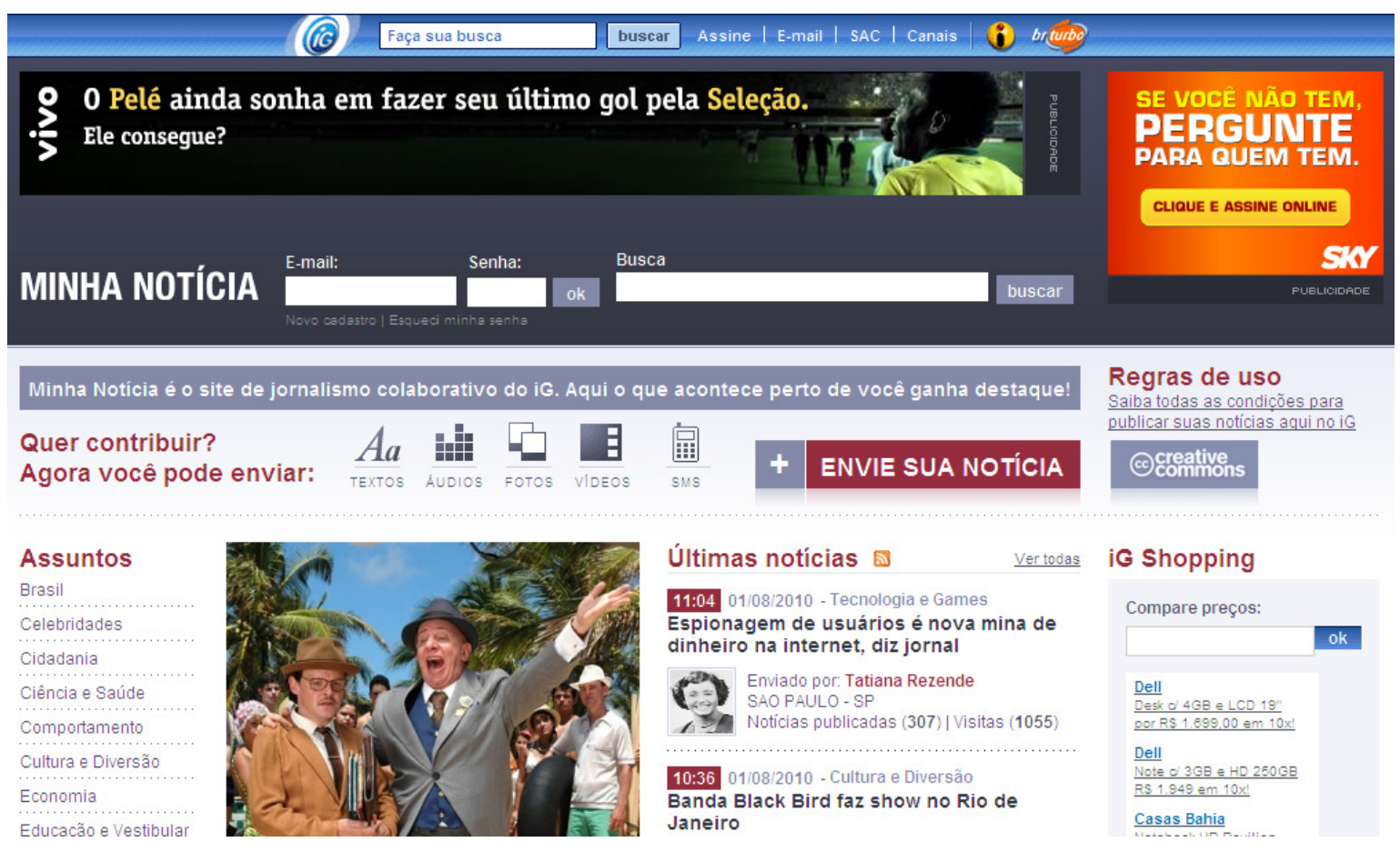

Minha Notícia (http:// minhanoticia.ig.com.br), do iG, excluido da amostra

Mesmo com o slogan "Aqui o que acontece perto de você ganha destaque", o serviço colaborativo do iG permitia frequentemente a publicação de materiais sem citação alguma de fontes, claramente reproduzidas de sites internacionais, e sem a correta identificação do autor -ironicamente, itens constantes de suas próprias regras de uso. Práticas como estas foram de encontro às premissas do jornalismo que adotamos como base de nosso trabalho acadêmico. Durante a primeira semana de análise, foi possível detectar material claramente reproduzido de outros veículos ${ }^{24}$ (especialmente pela distância entre a cidade de residência de alguns autores e o local de fatos abordados em seus materiais); uso do serviço para divulgação de sites comerciais ${ }^{25}$ (o quarto usuário com mais colaborações no serviço usa como avatar o logotipo de uma loja de produtos de limpeza, com link em seu perfil para tal site) ou de blogs, como é o caso dos usuários Super Pérolas ${ }^{26}$, Denispd ${ }^{27}$,

24 "Bêbado tenta obrigar policial a abraçá-lo e acaba detido". Disponível em <http://minhanoticia.ig.com.br/editoria/Inusitadas/ 2009/03/08/bebado+tenta+obrigar+policial+a+abraca+lo+e+acaba+detido+4588909.html>. Acesso em: 10 mar. 2009.

${ }^{25}$ Perfil de Armando Sales, de Fortaleza (CE). Disponível em < http://minhanoticia.ig.com.br/perfil/perfilHome.action?user id=334> Acesso em: 28 mar. 2009.

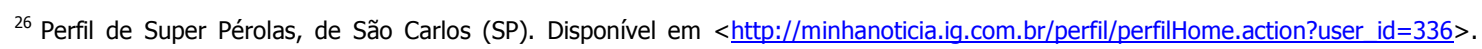
Acesso em: 28 mar. 2009. 
TRETANDO ${ }^{28}$ e Planeta Tosco $^{29}$, que compunham o ranking dos cinco usuários com maior volume de publicações no site; e excesso de material de divulgação e press-releases, como o caso dos canais "Turismo" ou "Cultura e Diversão", que permitem a publicação de notícias como "Itu recebe festa do Yakissoba" ${ }^{30}$ e "Vilãs Brilham no Hotel Cambridge em SP"31, ou um perfil como Star Produções ${ }^{32}$, claramente de empresa com fins lucrativos.

A Abril, último portal de Internet brasileiro a integrar a lista dos maiores websites em audiência no país, também não possuía, até a conclusão do levantamento, um serviço consolidado de jornalismo colaborativo.

Uma vez definidos os portais que participariam da amostra —observado aqui o critério da homogeneidade postulado por Fonseca Júnior e justificado anteriormente-, o processo de coleta de dados tomou por base a metodologia de observação nãoparticipante estruturada ${ }^{33}$ dos portais VC Repórter, do Terra, e VC no G1, da Globo.com, com observação e coleta das páginas de jornalismo colaborativo destes portais durante o período de 1/3/2009 a 15/3/2009, obtendo para análise 165 matérias publicadas. Observação não-participante, pois eximiria o pesquisador de qualquer envolvimento direto com o objeto, isentando o trabalho de qualquer movimento intencional ou interativo por parte do autor. Observação estruturada, pois partiu de roteiro de observação previamente elaborado, cujos parâmetros pautaram-se nas conceituações de jornalismo e jornalismo colaborativo obtidas a partir da revisão bibliográfica inicial.

\footnotetext{
27 Perfil de Denispd, de Belo Horizonte (MG). Disponível em < http://minhanoticia.iq.com.br/perfil/perfilHome.action?user_id=2335>. Acesso em: 28 mar. 2009.

${ }^{28}$ Perfil de Tretando, de São Carlos (SP). Disponível em <http://minhanoticia.ig.com.br/perfil/perfilHome.action?user_id=329>. Acesso em: 28 mar. 2009.

${ }^{29}$ Perfil de Planeta Tosco, do Rio de Janeiro (RJ). Disponível em < http://minhanoticia.í.com.br/perfil/perfilHome.action?user id=333 >. Acesso em: 28 mar. 2009.

30 "Itu recebe festa do yakissoba". Disponível em <http://minhanoticia.ig.com.br/editoria/Cultura Diversao/2009/03/01/ itu+recebe+festa+do+yakissoba+4386965.html >. Acesso em: 10 mar. 2009.

31 "Vilãs brilham no hotel Cambridge em SP". Disponível em < http://minhanoticia.ig.com.br/editoria/Cultura_Diversao/ 2009/03/01/vilas+brilham+no+hotel+cambridge+em+sp+4386963.html>. Acesso em: 10 mar. 2009

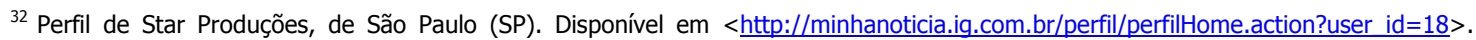
Acesso em: 10 mar. 2009

${ }^{33}$ A técnica de observação não-participante possibilita a observação do fenômeno investigado sem o envolvimento direto do pesquisador, isentando o trabalho de qualquer movimento intencional ou interativo por parte do mesmo. Em sua proposta de observação semi-estruturada definem-se alguns parâmetros de observação que conduzem a atividade de coleta de dados.
} 
O estudo desta amostra foi desenvolvido com base no método da análise de conteúdo, "técnica de pesquisa para a descrição objetiva, sistemática e quantitativa do conteúdo manifesto da comunicação", segundo Fonseca Júnior (2005 apud. DUARTE e BARROS, 2005, p. 282). Constituído o corpus, como acima mencionado, definimos como regra de enumeração a frequência de aparição dos critérios de categorização citados a seguir, obtidos junto ao nosso referencial teórico —classificamos as 165 notícias primeiramente pela área editorial a que se filiavam, de modo a conhecer os traços temáticos predominantes no noticiário colaborativo, além de mapear que critérios de noticiabilidade as matérias apresentavam, de acordo com nosso estudo conceitual. Identificamos também se os temas abordados tinham relação com o local de residência do colaborador e seu entorno geográfico, para avaliar o grau de hiperlocalismo do conteúdo colaborativo dos grandes portais. Em seguida, buscamos inquirir se o cidadão repórter meramente flagrou um acontecimento, seja por texto, foto ou vídeo, ou preocupou-se em obter informações adicionais, seja com outras testemunhas ou fontes oficiais. Neste caso, quantas fontes foram ouvidas? E essas fontes, caso acessadas, foram declaradas com precisão no decorrer do texto, de forma a emprestar-Ihe credibilidade? Por fim, também foi importante identificar se houve indícios de divulgação institucional nos materiais, prática que poderia expor o jornalismo colaborativo, e assim o próprio jornalismo, a discursos alheios ao interesse público, tal como alertam Kovach e Rosenstiel (2004, p. 24).

A seguir, apresentamos o modelo do questionário utilizado para o levantamento. 


\section{ROTEIRO DE OBSERVAÇÃO PARA LEVANTAMENTO DE DADOS (MODELO)}

Veículo de origem

$\square$ VC no G1

VC Repórter

Minha Notícia

Data de publicação

Título da matéria

URL da matéria

Área editorial
Cidades/Cotidiano
Internacional
Política
Economia
Cultura
Entretenimento
Tecnologia
Educação
Esportes
Outros

O autor aborda acontecimentos de sua região (hiperlocalismo)?

$\square$ Sim $\square$ Não

O material tem indícios de ser reprodução de outro veículo de mídia?

$\square \operatorname{Sim} \square$ Não

O material é mero flagrante/constatação da realidade?

$\square \operatorname{Sim} \square$ Não

O texto tem indícios de ser material de divulgação (press release)?

$\square \operatorname{Sim} \square$ Não

As fontes de informação são declaradas com precisão no texto?

$\square \operatorname{Sim} \square$ Não

Há no material indício claro de que foi o próprio autor a contatar as fontes de informação?

$\square$ Sim $\square$ Não

Quantas fontes de informação o autor cita no texto
$\square 0$ (zero)
$\square 1$ (uma)
$\square 2$ (duas)
3 (três) ou mais

A estrutura do texto contempla o lead jornalistico (pirâmide invertida)?

$\square \operatorname{Sim} \square$ Não

O material possui atributos jornalísticos? Quais?
$\square$ Atualidade
Conflito
$\square$ Proximidade
Curiosidade
Conhecimentos
Dramaticidade

Notoriedade
Consequências
Surpresa

O material possui imagem ou vídeo?
$\square$ Sim, imagem(ns)
Sim, vídeo(s)
Não

Se possui imagem ou vídeo, estes foram produzidos pelo autor do material?

$\square \operatorname{Sim} \square$ Não


Obtidos os resultados do estudo exploratório -a serem apresentados no próximo capítulo-, chegamos a novas questões sobre o jornalismo colaborativo nos portais de Internet brasileiros, o que criou a necessidade de empreendermos estudo qualitativo, em forma de entrevistas semi-estruturadas realizadas entre dezembro de 2009 e fevereiro de 2010 junto aos publishers de alguns portais, além de editores dos canais participativos destes concentradores de audiência da web brasileira e também nomes reconhecidamente referenciados no jornalismo online do país. Conversamos com a jornalista Erin Mizuta, editora do VC Repórter (Terra); com o professor de Direito da FGV e ativista do jornalismo colaborativo Ronaldo Lemos, fundador do site colaborativo cultural Overmundo; e com os jornalistas Caíque Severo, diretor de desenvolvimento editorial do iG; Márion Strecker, diretora de conteúdo do UOL; e Rodrigo Flores, gerente geral de notícias do UOL. Durante alguns meses tentamos entrar em contato com jornalistas do G1, site de jornalismo da Globo.com, porém sem sucesso. Diretamente, por contatos do autor, havia receio de algum tipo de punição pela divulgação de dados internos da companhia. O serviço Globo Universidade (http://globouniversidade. globo.com), apontado por um dos jornalistas do G1 como único canal de comunicação possível para entrevistas com profissionais da empresa, também não respondeu a solicitações do autor por telefone e e-mail.

Nosso objetivo nesta fase final do trabalho foi contrastar as inferências obtidas através do estudo exploratório às referências teóricas e às práticas de mercado sobre o jornalismo colaborativo no Brasil, especificamente no âmbito dos grandes portais de mídia. Lançamos mão do método da análise de conteúdo e decidimos por permear a análise quantitativa de dados empreendida no capítulo 4 com as respostas obtidas junto aos nossos entrevistados, de maneira a melhor confrontar os dados e realçar conflitos de ponto de vista.

Para empreender esta fase da pesquisa, utilizamos o seguinte roteiro de perguntas: 


\section{ROTEIRO INICIAL DE ENTREVISTA :: DIRETORES DE REDAÇÃO}

1. O que é o jornalismo colaborativo, em seu ponto de vista?

2. As notícias que estampam a home page de seu portal seriam muito diferentes sem o jornalismo colaborativo? Por quê?

3. Por que redes sociais como Orkut ou MSN são tão populares no Brasil, mas o jornalismo colaborativo nem tanto?

4. Você considera o internauta que participa de seu serviço de jornalismo realmente um cidadãorepórter? Ou ele teria uma função, hoje, mais semelhante à de uma fonte de informação?

5. O jornalismo colaborativo de seu veículo pode ser comparado ao exercido por sites como o OhMyNews (Coréia do Sul) ou o iReport (EUA)? Seu portal se inspirou em serviços como estes para criar seu modelo de jornalismo colaborativo?

6. O jornalismo colaborativo dá ou pode dar certo em grandes portais de conteúdo? Ou é um fenômeno que ficará relegado a sites independentes? Por quê?

7. O jornalismo colaborativo é uma forma de baratear a produção de conteúdo? Por quê?

8. Não será mais difícil às pessoas, em um contexto de excesso de informação, lidar com mais e mais conteúdo em um contexto de construção coletiva de material? O jornalismo colaborativo não será, portanto, mais "difícil" que o jornalismo tradicional?

9. O jornalismo colaborativo pode substituir, hoje ou no futuro, o jornalismo tradicional? Por quê? 


\section{ROTEIRO INICIAL DE ENTREVISTA :: EDITORES E REDATORES}

1. O que é o jornalismo colaborativo, em seu ponto de vista?

2. Qual é a área editorial (cidades, cultura, economia) com maior apelo para produção de conteúdo por parte dos internautas de seu serviço de jornalismo colaborativo? Por quê?

3. Há uma maior tendência no jornalismo colaborativo de seu portal a valorizar os acontecimentos da região onde vivem os autores das matérias? Qual a razão disso, em sua opinião?

4. Já houve casos em que autores enviam reproduções de matérias de outros veículos? Como esse tipo de caso é tratado pela redação?

5. E material de divulgação/press-releases? O jornalimo colaborativo é mais suscetível a esse tipo de conteúdo? Como a redação se previne?

6. Os internautas que participam do serviço de jornalismo colaborativo de seu portal apuram informações antes de as submeterem? Que métodos usam (entrevistas, pesquisa, registro fotográfico/taquigráfico)? Como a redação "confia" nos seus colaboradores?

7. Como a redação trabalha com o material recebido de internautas? Existe checagem das informações? É feita algum tipo de apuração adicional/ enriquecimento dos dados?

8. O mero flagrante de um acidente, uma chuva forte ou registro de um show pode ser considerado jornalismo colaborativo? Como a redação trabalha com esse tipo de material?

9. E o registro pessoal sobre uma obra de arte, um carro próprio ou situação vivida pelo internauta? Textos em primeira pessoa são considerados para o noticiário colaborativo? Por quê?

10. Você considera o internauta que participa de seu serviço de jornalismo realmente um cidadãorepórter? Ou ele teria uma função, hoje, mais semelhante à de uma fonte de informação?

11. O jornalismo colaborativo de seu portal tem a mesma credibilidade que o noticiário profissional? O que diferencia os dois, em seu ponto de vista?

12. Por que redes sociais como Orkut ou MSN são tão populares no Brasil, mas o jornalismo colaborativo nem tanto? O jornalismo colaborativo está dando certo no Brasil? Por quê? 
Apesar da adoção de métodos científicos que embasaram a coleta de dados e nortearam a pesquisa como um todo, devemos entretanto ressaltar as limitações do estudo —que não pretende generalizar conceitos sobre o jornalismo colaborativo em si, mas trazer à luz alguns dilemas que a prática encontrou em sua adoção pela grande imprensa na Internet brasileira.

Nosso estudo também não se debruça, por exemplo, sobre o cenário de mídia colaborativa independente, que, apesar de não possuir o mesmo potencial de audiência dos grandes portais do país, parece ter maior capacidade de absorver conteúdo de fontes mais abrangentes e não hegemônicas, o que lhe confere, em tese, maior capacidade de democratizar o acesso à comunicação.

De maneira mais abrangente, podemos também determinar a limitação do estudo diante da relativização de qualquer abordagem científica em relação à realidade objetiva. O conhecimento científico em si é como um prisma pelo qual é possível enxergar o mundo. Como postulam Barros e Junqueira (2005 apud DUARTE e BARROS, 2005, p. 34):

\begin{abstract}
"Aquilo que os seres humanos percebem ao observar o mundo é produto de uma operação muito complexa, na qual estão envolvidos o sujeito observador, o objeto observado, os esquemas interpretativos utilizados pelo observador e o contexto em que tal observação se dá e adquire ou encontra sentido. Isso sem falar que, no caso das ciências sociais (no interior das quais a comunicação se inclui), os objetos observados não são jamais uma coisa inerte, sem vontade própria. Eles podem interagir com o observador e, inclusive, reagir a suas interpretações, pois são sujeitos dotados de capacidade auto-reflexiva e fornecem, eles mesmos, interpretações acerca de suas situações. E ainda mais: não se pode esquecer que a própria presença do observador em determinado cenário já produz alterações no panorama observado. (...) Em outras palavras: o objeto de estudo é construído no âmbito de uma relação social, e por isso não pode existir de forma autônoma da perspectiva teórica adotada e do contexto no qual ela é empregada."
\end{abstract}

De acordo com Barros e Junqueira (2005), é possível inferir, portanto, que os problemas, objetivos e hipóteses de nosso trabalho nasceram de uma relação do pesquisador, seus entrevistados e o objeto, em um contexto sociocultural em que as tradições consolidadas, o histórico cultural, as opções ideológicas e as experiências de vida se fundem, confrontam, adéquam-se e transformam-se pelo contato. 
Em nosso caminho intelectual, tanto na construção das hipóteses como nas sugestões para estudos futuros, acabamos flertando também com a fenomenologia -neste momento, debruçados sobre os dados obtidos em campo e na literatura, buscamos validar as provas científicas no processo lógico da interpretação e na capacidade de reflexão do pesquisador sobre o fenômeno, objeto de estudo.

\footnotetext{
"As abordagens fenomenológicas-hermenêuticas privilegiam estudos teóricos e análise de documentos e textos. Suas propostas são críticas e, geralmente, têm marcado interesse de conscientização dos indivíduos envolvidos na pesquisa. Manifestam interesse por práticas alternativas, e se utilizam de técnicas não-quantitativas. Buscam relação entre o fenômeno e a essência, o todo e as partes, o objeto e o contexto." (MARTINS, 1994, p. 3)
}

Também pela opção de uma apreensão crítica da realidade, acabamos por defrontar nossas hipóteses iniciais às visões dos entrevistados, adotando uma visão do conhecimento científico como conhecimento crítico. Pensamento crítico que "desconfia de suas próprias conclusões, submetendo suas investigações e conclusões ao olhar crítico de outros analistas, que, por sua vez, poderão propor novas interpretações" (2005 apud DUARTE E BARROS, 2005, p. 36).

Após as análises quantitativas e qualitativas do noticiário colaborativo dos grandes portais brasileiros, e em linha com insights e opções ideológicas do autor, deixamos alguns apontamentos para estudos futuros, baseados principalmente em três vertentes. Primeiro, com o intuito de buscar caminhos para fomentar a participação do público, estabelecemos um paralelo entre a Pedagogia do Oprimido de Paulo Freire e a colaboração online, em busca de compreender que perfil e que limitações o cidadãorepórter brasileiro, ainda em potencial, terá de vencer para tomar parte ativa neste novo cenário midiático, já que "a conduta da vida social depende crucialmente dos recursos simbólicos disponíveis. A comunicação antecipa ações sociais e configura a estrutura social" (JENSEN, 2008, p. 36). 
Em seguida, emprestamos conceitos de Murray (2003) para abordar as transformações que o universo digital trouxe ao conceito de autoria, e portanto, à realidade do jornalista — como o profissional deve lidar com a autoria coletiva e um contato em tempo real com seu (antigo) público, (agora) autor de conteúdos?

Por fim, para melhor compreender as limitações no engajamento do público brasileiro com o jornalismo colaborativo, tentamos traçar um breve contexto de nossas raízes históricas com a ajuda de Castells (2000) e Holanda (2004). 


\section{JORNALISMO COLABORATIVO NOS PORTAIS BRASILEIROS}

Retomando o objetivo de compreender se as iniciativas de jornalismo colaborativo dos grandes portais brasileiros — que apresentam significativa audiência e atratividade diante do público- conseguiram abarcar a colaboração com profundidade e abrangência semelhantes às obtidas em experiências internacionais como as estudadas por Brambilla (2005) e Bruns (2005), estruturamos um estudo exploratório de campo com notícias dos sites participativos de Globo.com e Terra.

A primeira etapa da análise de conteúdo empreendida pela pesquisa foi classificar as notícias de acordo com área editorial a que se filiavam. Das 165 notícias analisadas, 105 abordavam temas ligados à editoria de Cidades, em que incluímos assuntos ligados ao cotidiano, como trânsito ou registros das condições do clima. Os assuntos que mais se destacaram neste grupo foram acidentes de trânsito próximos ao local de residência dos colaboradores e estragos relacionados à temporada de chuvas do final do verão brasileiro.

\section{GRÁFICO 1}

Notícias por Área Editorial

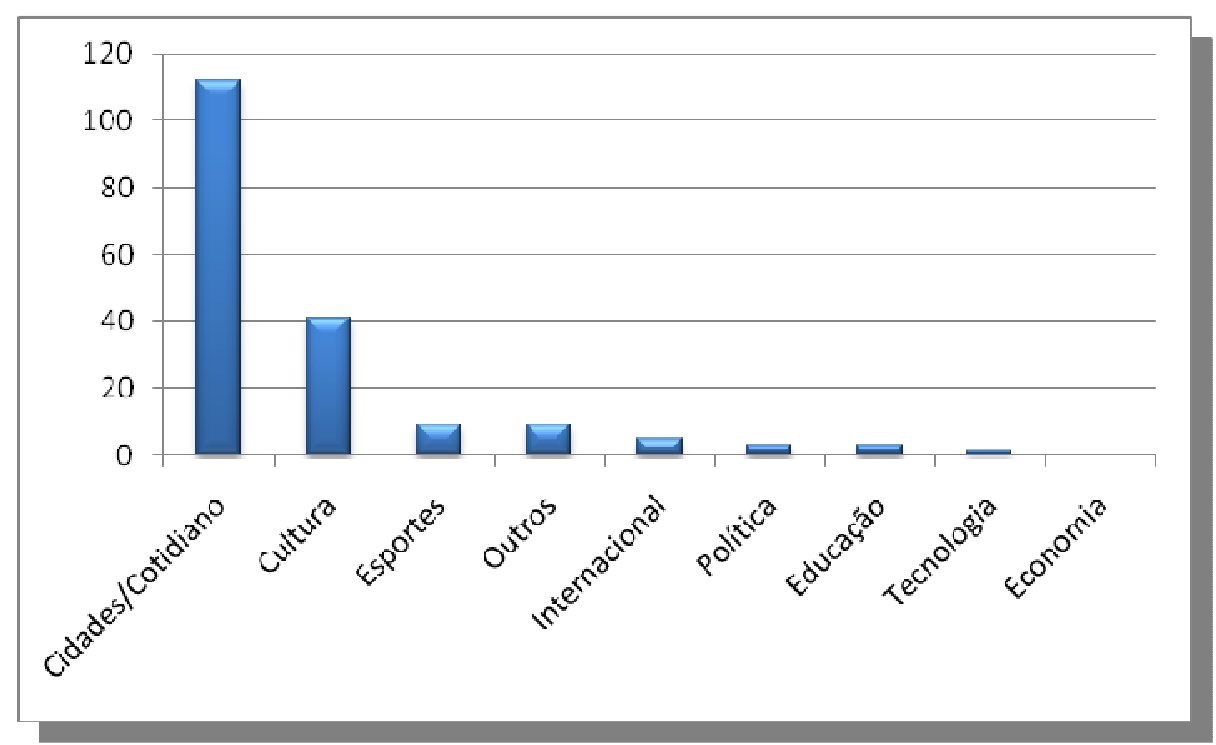


Em segundo lugar aparecem 41 matérias com temas ligados à Cultura e Entretenimento, com a maior incidência de registros de shows. Em terceiro lugar aparecem matérias de Esportes, com registros de competições locais ou a visita de grandes times nacionais a cidades do interior, como o caso do jogo do Corinthians em Marília $^{34}$, no contexto da expectativa pela estreia do jogador-celebridade Ronaldo. Por fim, a categoria Outros reúne matérias de serviços ou material considerado pela pesquisa como reprodução de material de divulgação ou press releases. Por fim, temas internacionais, ligados à educação, à política e à tecnologia somam juntos apenas dez matérias, menos de $10 \%$ da amostra.

A jornalista Erin Mizuta, editora do VC Repórter, do Terra, confirma em entrevista ao autor que a editoria de Cidades é a mais utilizada, seguida pela de trânsito — cujo material contabilizamos também na área de Cidades/Cotidiano. Segundo Mizuta:

\begin{abstract}
"A maioria são notícias do cotidiano, fatos que afetam diretamente o leitor. São fatos fáceis de serem distinguidos como notícia: acidentes de trânsito, buracos e problemas em ruas ou estradas, alagamentos e árvores caídas são bem freqüentes. Fatos relacionados a chuvas e demais fenômenos climáticos são sempre assunto. Manifestações também contam sempre com registros de colaboradores." ${ }^{15}$
\end{abstract}

A predominância de material ligado à vida cotidiana também ocorre no VC no G1, porém, não pudemos contar com depoimentos de jornalistas da Globo.com sobre o site, conforme detalhado no capítulo anterior.

Definidos os temas de maior interesse —atributo de definição do jornalismo, segundo Chaparro (1993, p. 120) - procuramos identificar que critérios de noticiabilidade foram utilizados com maior freqüência pelos cidadãos-repórteres ao enviar material aos editores dos sites colaborativos dos portais Terra e Globo.com. Em primeiro lugar, com 146 matérias, apareceu o critério da atualidade, seguido de perto pela proximidade, com 130

\footnotetext{
34 "Torcida lota estádio de Marília para ver Ronaldo". Disponível em: <http://g1.globo.com/VCnoG1/0,„MUL1024177-8491,00.html> Acesso em: 10 mar. 2009.

${ }^{35} \mathrm{Em}$ entrevista ao autor.
} 
notícias. Nitidamente, os cidadãos-repórteres registravam acontecimentos que de alguma forma flagravam em seu dia-a-dia, fossem acidentes, shows, flagrantes de variações climáticas e suas conseqüências etc.

\section{GRÁFICO 2}

Notícias por Critério de Noticiabilidade

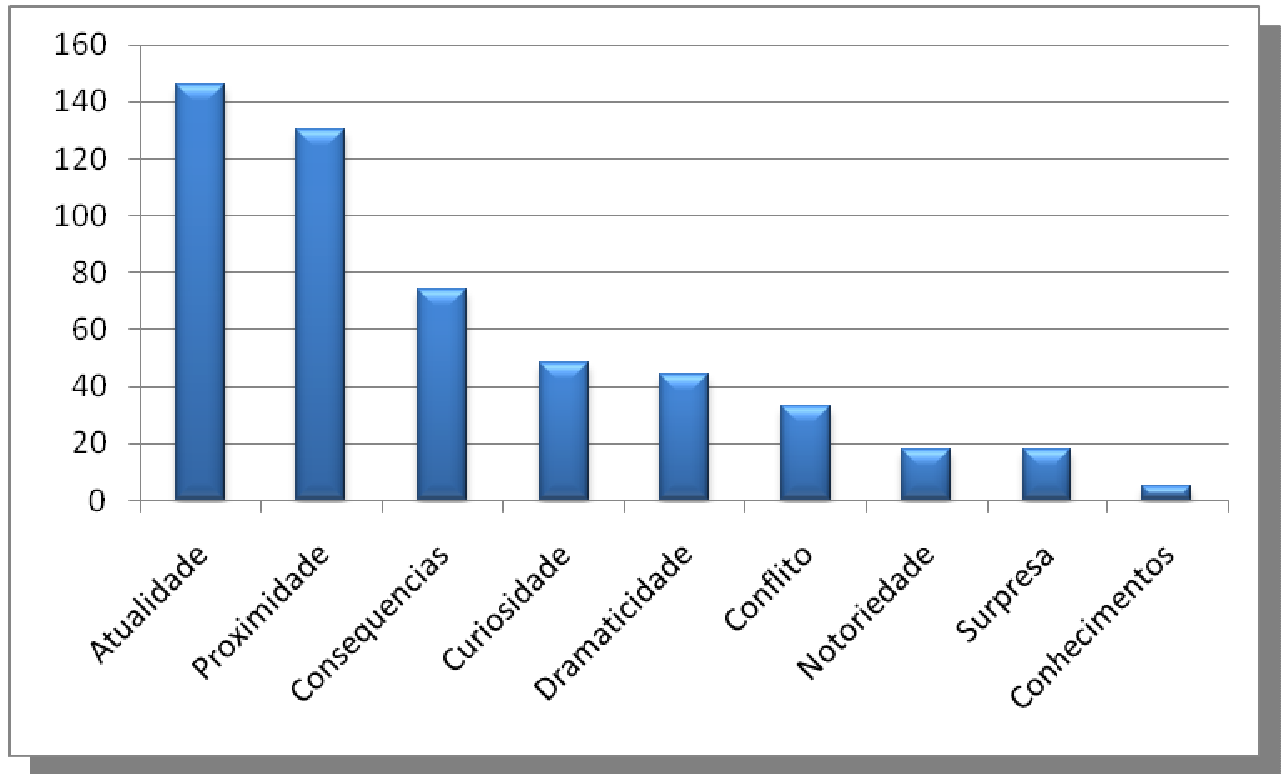

Em seguida temos 73 matérias que utilizam as conseqüências do fato como valornotícia. A maioria era relacionada a acidentes ou a denúncias sobre má conservação de vias ou outras instalações públicas. Curiosidade é o próximo critério utilizado com mais frequência, com um total de 48 matérias -aqui a variedade dos temas vai de "Cores no céu intrigam moradores de SP e do $\mathrm{RS}^{\prime \prime 36}$, publicada pelo VC Repórter, do Terra, a "Eu tenho um carro nas cores prata e rosa" ${ }^{\prime 37}$, registrada no VC no G1, da Globo.com.

36 "Cores no céu intrigam moradores de SP e do RS". Disponível em: <http://noticias.terra.com.br/ciencia/interna/0,_OI3608952EI238,00.html>. Acesso em: 10 mar. 2009

37 "Eu tenho um carro nas cores prata e rosa". Disponível em: <http://q1.globo.com/VCnoG1/0,MUL1039574-8491,00.html>. Acesso em: 10 mar. 2009. 
Dentro deste critério surgiram materiais bastante peculiares, como "Temos xodó pelo nosso carro Zé do Caixão" ${ }^{38}$, publicada pelo VC no G1 -simples relato pessoal e extremamente breve, poderia ser considerado "notícia"?

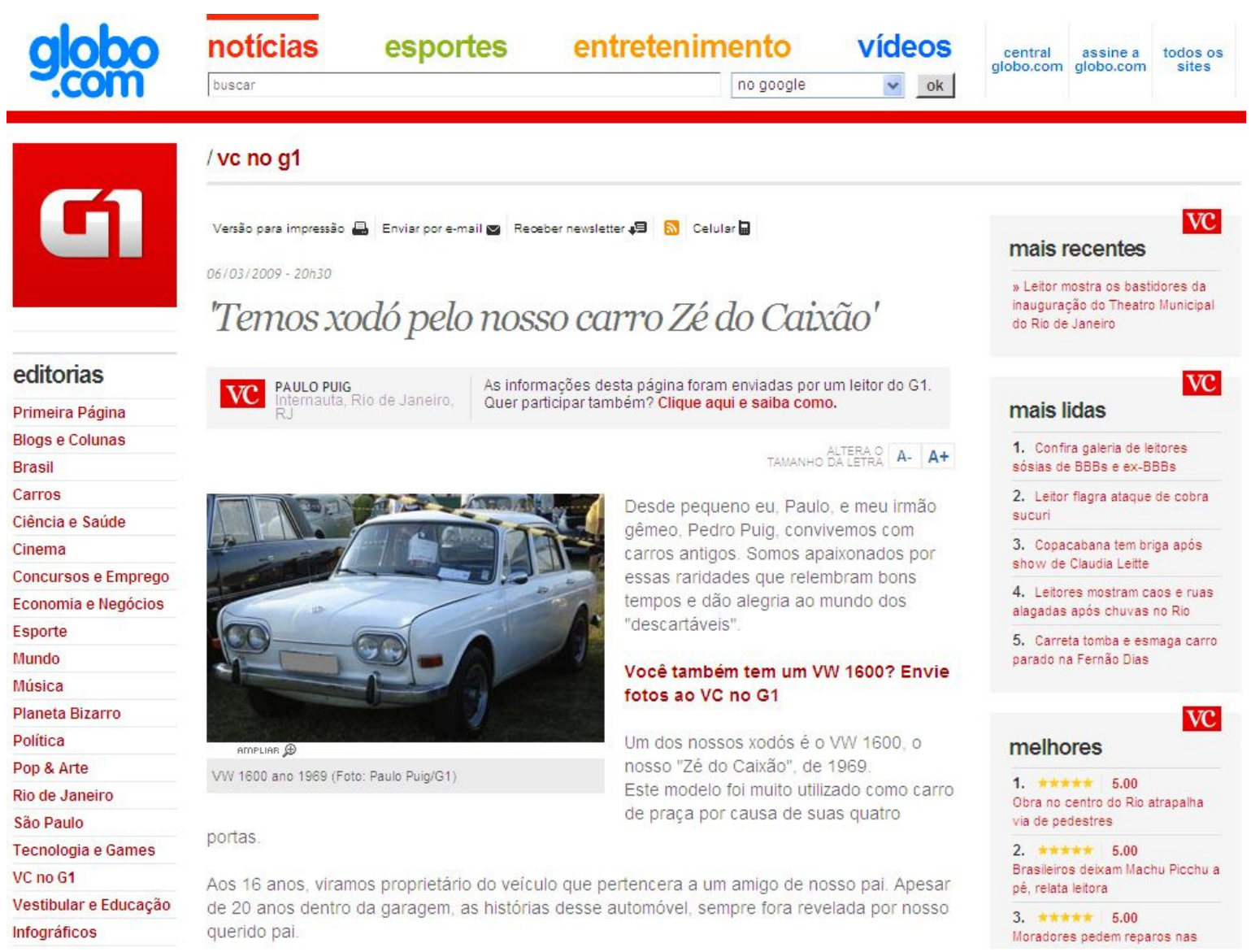

Notícia "Temos xodó pelo nosso carro Zé do Caixão", publicada pelo VC no G1, da Globo.com

Nem mesmo as histórias do automóvel, que eventualmente poderiam gerar um texto literário, porém de certo interesse jornalístico aos aficionados por carros antigos, são compartilhadas pelos autores. Ilustrado por duas fotos do VW 1600 do "cidadão-repórter", o item foi classificado apenas com o critério de Curiosidade, enquanto outros, tidos efetivamente como notícia, normalmente reuniam mais de um critério ao lado daquele. 0 que nos leva a questionar: pode um material desta natureza ser considerado como

38 "Temos xodó pelo nosso carro Zé do Caixão". Disponível em: <http://g1.globo.com/VCnoG1/0,MUL1031868-8491,00.html>. Acesso em: 10 mar. 2009. 
jornalismo colaborativo? Mizuta, do VC Repórter, acredita que em alguns casos o relato pessoal pode sim ser valioso para o noticiário:

\begin{abstract}
"Depende do tipo de texto. Artigos ainda não possuem espaço no VC Repórter, mas há a possibilidade de que essa divisão venha a existir. O leitor ainda confunde um texto opinativo com notícia, principalmente em casos políticos. Relatos de uma viagem, por exemplo, são publicados e com grande proveito."
\end{abstract}

Ela diz que o leitor "ajuda na composição do noticiário do portal, podendo ser essa colaboração parcial, com apenas uma foto, ou integral, com uma notícia completa". Assim prega o manual de redação do portal, segundo Mizuta: "Se o leitor achou que o material enviado é uma notícia, é o nosso papel entender o motivo e, de preferência, garantir espaço para aquele conteúdo". O que, na visão do professor Ronaldo Lemos, doutor em Direito Civil, ativista de Internet e fundador do site colaborativo Overmundo, mostra a diversidade de vozes da rede mundial de computadores:

\begin{abstract}
"Há relatos pessoais, totalmente individualizados, verdadeiros tesmunhos no Overmundo. E há jornalistas mesmo, graduados ou graduandos, que usam o site para fazer jornalismo propriamente dito. $\mathrm{O}$ que acho mais interessante é que isso é produto das diferentes motivações que levam as pessoas a participarem do site. Alguns querem dar visibilidade a uma atividade local, outros querem mesmo criar um relato objetivo, outros querem polemizar e assim por diante. No fundo, o resultado é uma combinação muito rica, que mostra que há muitas mídias e muitas mensagens diferentes dentro da Internet." ${ }^{139}$
\end{abstract}

Por fim, o levantamento registrou os critérios dramaticidade (44 matérias), conflito (33), notoriedade (18), surpresa (18) e conhecimentos (5). O baixo volume de notícias com este último critério também nos leva a inferir que, diferentemente da experiência do site OhMyNews, há poucos especialistas em suas áreas de atuação que dispõem-se a participar do cenário colaborativo no jornalismo dos grandes portais brasileiros. Ao contrário do que acontece com o OhMyNews, que "encoraja [seus] cidadãos-repórteres a

\footnotetext{
${ }^{39} \mathrm{Em}$ entrevista ao autor
} 
escrever matérias de acordo com seus trabalhos, atitudes, interesses ou áreas de especialização". ${ }^{40}$

Em paralelo ao grande volume de matérias com o critério da proximidade, foi possível registrar também um grande volume de publicações com tendência ao hiperlocalismo. A maioria das notícias avaliadas (90\%) aborda fatos ocorridos no entorno físico dos cidadãos-repórteres. Optamos, portanto, em apresentar e incluir tais resultados em nossos parâmetros de pesquisa.

\section{GRÁFICO 3}

Abordagem hiperlocal

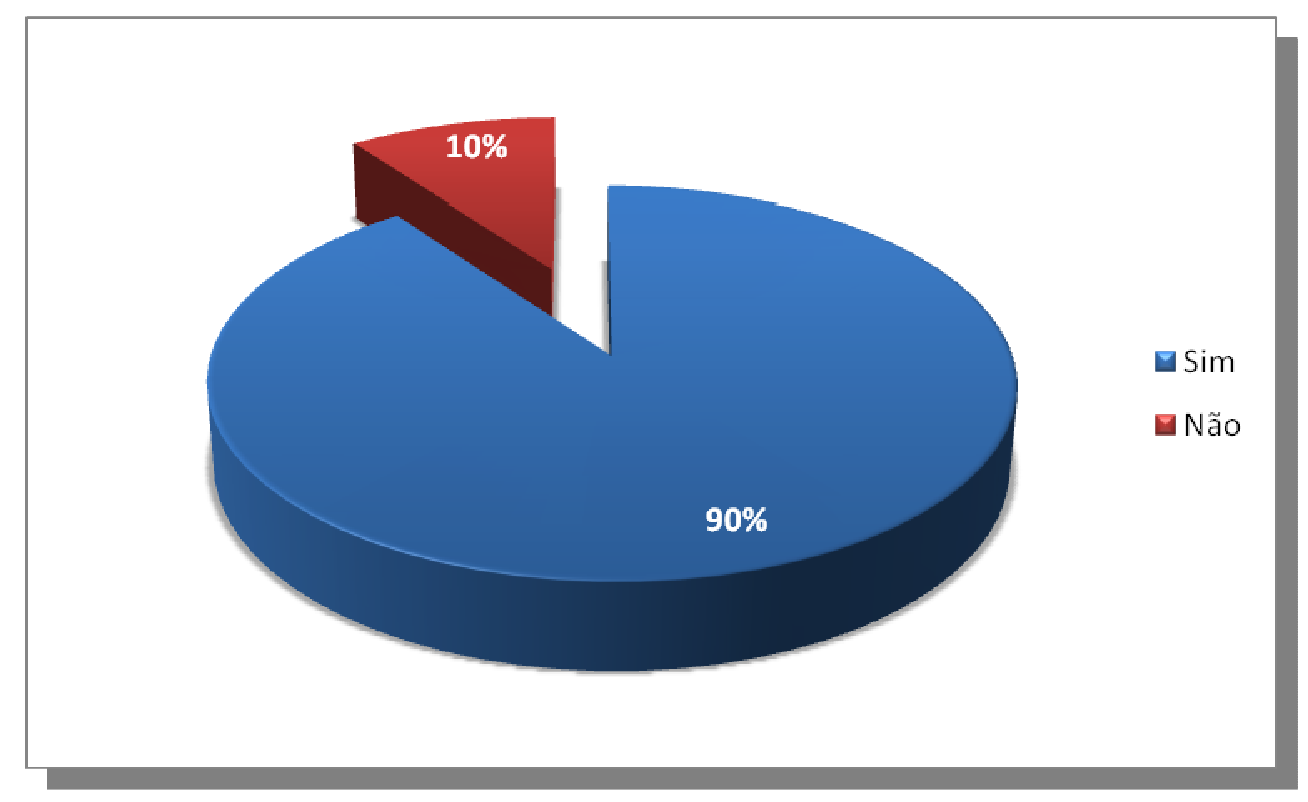

Para embasar o conceito de hiperlocalismo utilizamos as idéias de Mark Glaser (2007), que descreve o fenômeno nos Estados Unidos:

40 "OhMyNews FAQ: Can I make a press release an article?". Disponível em: <http://english.ohmynews.com/reporter room/ qa board/qaboard_list.asp?div code=56>. Acesso em: 12 ago. 2009. 
"Notícias hiperlocais são informações relevantes para pequenas comunidades ou vizinhanças que foram negligenciados pela mídia tradicional. Graças ao baixo custo de ferramentas de publicação e comunicação online, sites independentes de notícias hiperlocais começaram a surgir para servir a estas comunidades, enquanto a mídia tradicional procura iniciativas próprias para cobrir o que têm perdido. Em alguns casos, sites hiperlocais deixam qualquer pessoa enviar matérias, fotos ou vídeos da comunidade, com variados graus de moderação e filtros."

A definição de Glaser vai ao encontro do conceito de hiperlocalismo de Shaw (2007), para quem esse tipo de iniciativa tem se mostrado uma forma de engajar leitores que têm fugido da mídia tradicional:

\begin{abstract}
"Não há definição oficial, mas geralmente um site de notícias hiperlocais (também conhecidos por microsites) é devotado às histórias e minúcias de uma vizinhança particular, CEP ou grupo de interesses em uma certa área geográfica. Tais sites têm florescido na Internet há algum tempo, inicialmente como startups independentes, criadas e mantidas pela dedicação dos fundadores, que trabalham com orçamento bastante restrito. Outros sites fazem dinheiro (apesar de geralmente não muito) ao oferecerem espaço publicitário barato para negócios locais -o restaurante regional, lavanderias ou lojas de artesanato que geralmente não conseguem pagar anúncios em publicações que abrangem toda a cidade. Alguns sites hiperlocais têm conteúdo produzido ao menos em parte por jornalistas profissionais e pagos. Muitos outros não têm."
\end{abstract}

Mizuta, do VC Repórter, acredita que esta é "a origem e o sentido do jornalismo colaborativo". Segundo ela, o noticiário participativo tende a ser regionalista em uma primeira fase, e o internauta, na grande maioria das vezes, fala sobre o que acontece à sua volta, sobre o que lhe afeta diretamente e o seu entorno:

\begin{abstract}
"Ele pode falar da árvore que caiu na frente da casa dele, do buraco na rua do bairro, do problema de água na cidade. Em raros casos ele vai flagrar um acidente que acontece longe do seu trajeto cotidiano. Em uma segunda instância, que já conseguimos atingir aqui no VC Repórter, ele vai falar sobre um destino turístico que visitou, sobre o anúncio de uma banda, ou a morte de um esportista. Mas tudo ligado ao círculo de interesse dele."
\end{abstract}

Interessante notar a tendência hiperlocal do jornalismo colaborativo dos portais para contrastá-la ao comportamento comum da grande mídia brasileira, inclusive na Internet. Como veremos nos desafios e caminhos do cenário brasileiro traçados no capítulo 5 , esta tendência vai de encontro à freqüência com que material produzido por agências internacionais de notícias é reproduzida e utilizada no noticiário tradicional, o que acaba 
por minimizar o contato do brasileiro com sua própria realidade. Tendência que o jornalismo colaborativo poderia reverter nos grandes portais -e que já ensaia fazer, especialmente em casos de grandes tragédias, como descreve Rodrigo Flores, do UOL:

\begin{abstract}
"No mínimo, o conteúdo do público complementa o nosso trabalho. Em alguns casos, ele é o nosso trabalho, é fundamental. Porque às vezes é o único recurso. Um exemplo foi o desabamento da ponte em Agudos (RS). Não temos repórter lá. A única forma de conseguir rapidamente registros do local seria acionar o público. Outro exemplo? São Luiz do Paraitinga. A cidade foi devastada. Fizemos um "antes-e-depois" [álbum com fotos dos locais antes e depois da enchente que ocorreu em 2009], pedimos ajuda aos internautas. As pessoas publicam fotos no UOL Mais, fazemos um filtro do que chega, e as imagens mais legais publicamos no template de notícias, identificadas com uma marca d'água. Muitas vezes a gente mistura conteúdo do público e conteúdo do UOL." ${ }^{41}$
\end{abstract}

\title{
FLAGRANTE VS. APURAÇÃO
}

Mas o "conteúdo do público"

GRÁFICO 4

Matérias com apuração

obedece ao critério de apuração e checagem dos fatos, tão caro ao jornalismo? O público brasileiro já consegue exercer um "papel ativo" no processo de coleta e processamento de informações, como pregam Bowman e Willis (2003,

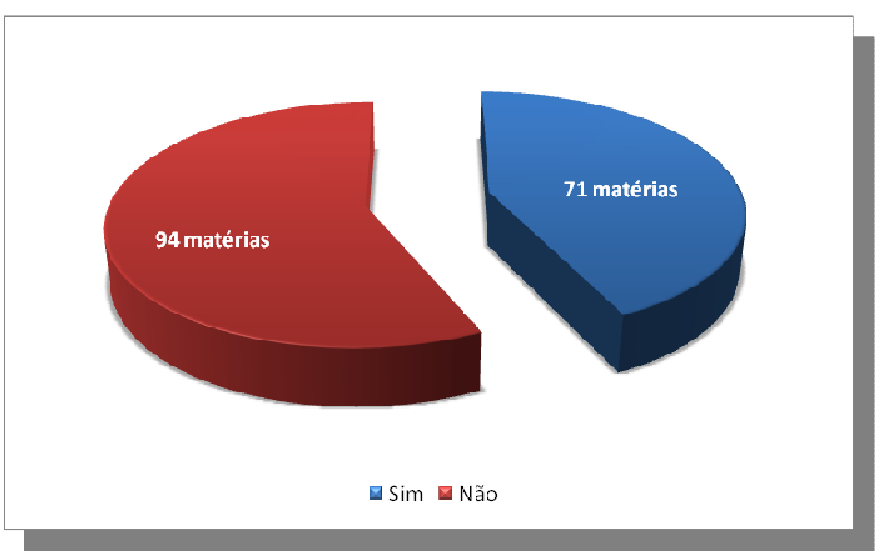

p. 9)? Para tentar responder a estas questões, o estudo procurou diferenciar o material publicado nos veículos colaborativos brasileiros quanto ao grau de apuração que demonstravam. Das 165 matérias avaliadas, 43\% (71) foram identificadas como mero flagrante da realidade. Aqui entendemos o flagrante como um simples registro de um acontecimento em foto ou vídeo, sem informações de contextualização ou checagem de dados com fontes oficiais e/ou testemunhas, o que ocorreu em mais da metade (57\%)

\footnotetext{
${ }^{41} \mathrm{Em}$ entrevista ao autor.
} 
dos casos. Neste critério de avaliação emerge uma diferença significativa entre VC Repórter e VC no G1 quando observados individualmente. No serviço do portal Terra, apenas 35\% (27) das notícias foram consideradas como flagrante da realidade, contra 75\% (44) do material publicado pelo site de jornalismo participativo da Globo.com.

O número traz duas percepções - a primeira sobre o VC Repórter, em que fica nítido o trabalho da redação do portal Terra no enriquecimento das informações enviadas à redação, realidade confirmada posteriormente em entrevista com a editora do canal, que falou sobre a atuação dos usuários na maior parte dos casos:

\begin{abstract}
"Eles colhem informações no local por observação, com os envolvidos, com fontes oficiais. Alguns deles até mesmo nos sugerem telefones das fontes com quem a matéria pode ser checada. No entanto, não usamos apenas essas fontes. Todo o material é checado antes de ser publicado, invariavelmente. A apuração parte das informações do leitor. Portanto, ele funciona realmente como um pauteiro/repórter. As entrevistas são utilizadas apenas quando conseguimos checar a declaração obtida pelo leitor. (...) Todas as informações são checadas e novos dados são adicionados para compor a matéria. Na maioria dos casos, o texto é feito ou enriquecido pelos nossos redatores, pois raras vezes eles chegam de acordo com as normas editoriais do portal para publicação." ${ }^{42}$
\end{abstract}

A segunda percepção é sobre o VC no G1, que poucas vezes enriquece a informação enviada pelos participantes e, ao valorizar o flagrante por si só, acaba por colaborar com um processo descrito por Ignácio Ramonet (1999, p. 34) como a transformação do jornalismo em instantaneísmo. Segundo o autor, o processo teve origem no início da década de 1990, com o auge da televisão por satélite, que transformou a mera transmissão de dados de um ponto a outro do globo em "reportagem", gênero jornalístico diverso da reprodução de um fato, qualquer que seja o veículo de comunicação. Um exemplo de flagrante é a matéria "Tempestade com raios assusta Blumenau" ${ }^{43}$. Com apenas dois parágrafos, sem consulta a fontes e com fotos de relâmpagos, o material é intitulado de "reportagem" pelo site:

\footnotetext{
${ }^{42}$ Em entrevista ao autor.

43 "Tempestade com raios assusta Blumenau". Disponível em: <http://q1.globo.com/VCnoG1/0 „MUL1041933-8491,00.html>. Acesso em: 20 mar. 2009.
} 


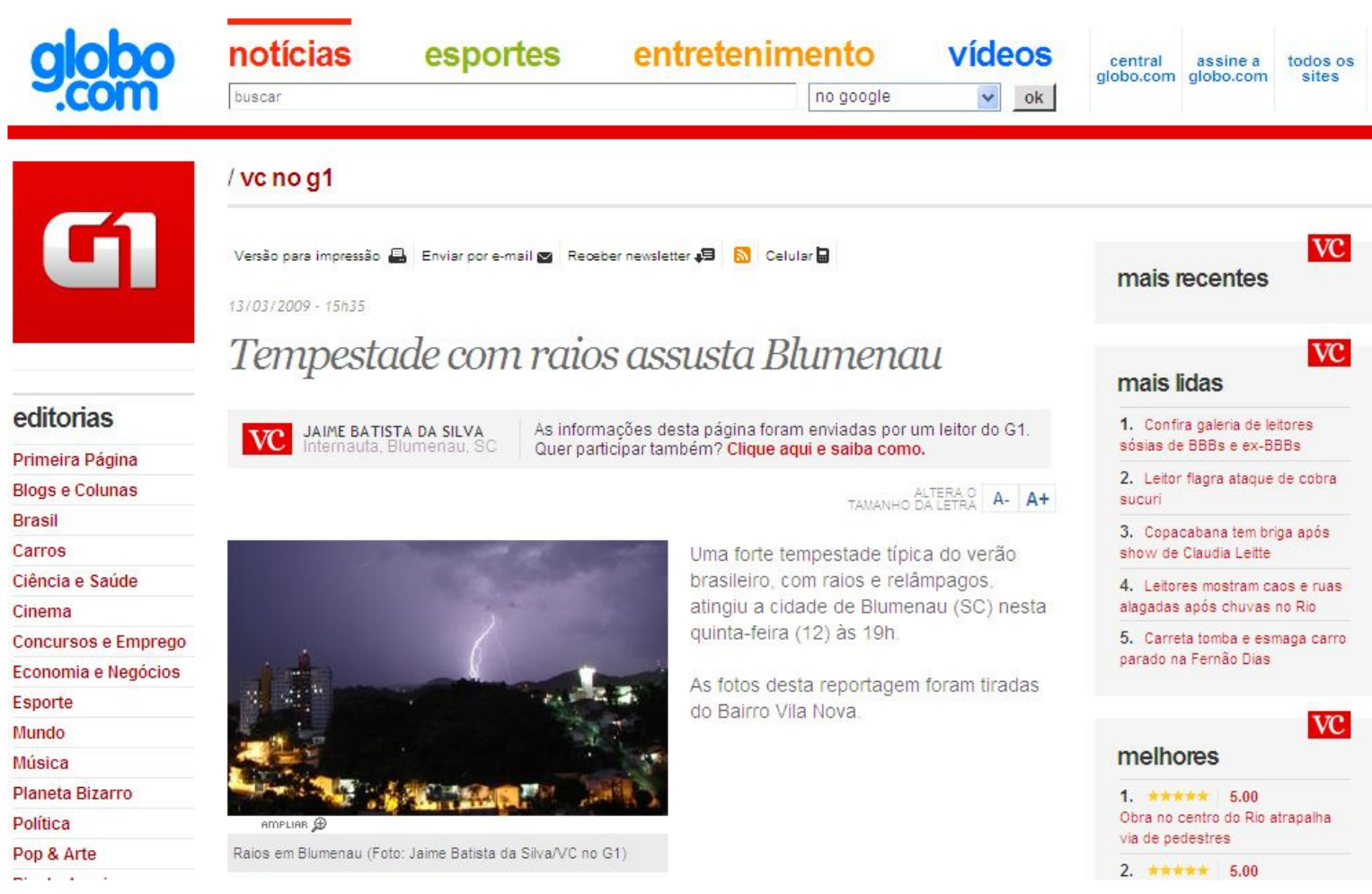

Notícia "Tempestade com raios assusta Blumenau", publicada pelo VC no G1, da Globo.com

O mero flagrante também leva a casos como o de "Homens pegam 'carona' em traseira de caminhão na Zona Sul de SP"144, publicada pelo VC no G1. "Vale lembrar que atitudes como essa podem causar graves acidentes, especialmente em casos de freada brusca", diz o texto, sem creditar a informação a nenhuma fonte especializada. Ao admitir a publicação de generalidades, o site da Globo.com expõe seu serviço colaborativo à falta de critérios jornalísticos e, em conseqüência, põe em xeque sua própria credibilidade.

O uso freqüente de material flagrante da realidade nos serviços colaborativos dos grandes portais tem relação direta com o baixo número de fontes citadas nos textos. Em 50\% (83) das matérias analisadas, não há citação de nenhuma fonte. Em outros 33\% (55) dos casos, apenas uma fonte de informação é mencionada -em alguns casos, a fonte é o próprio cidadão-repórter, o que vai de encontro à consulta de fontes como forma de atribuir credibilidade ao trabalho jornalístico. Em 14\% (23) das matérias são citadas duas fontes, e em apenas duas matérias, ou $1 \%$ dos casos, são citadas três ou mais fontes.

44 "Homens pegam 'carona' em traseira de caminhão na Zona Sul de SP". Disponível em: <http://g1.globo.com/VCnoG1/

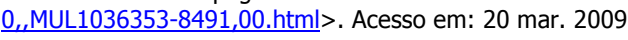


Quando analisados individualmente, os sites de jornalismo participativo do Terra e da Globo.com também demonstram diferentes abordagens.

\section{GRÁFICO 5}

Numero de fontes por matéria em cada veículo

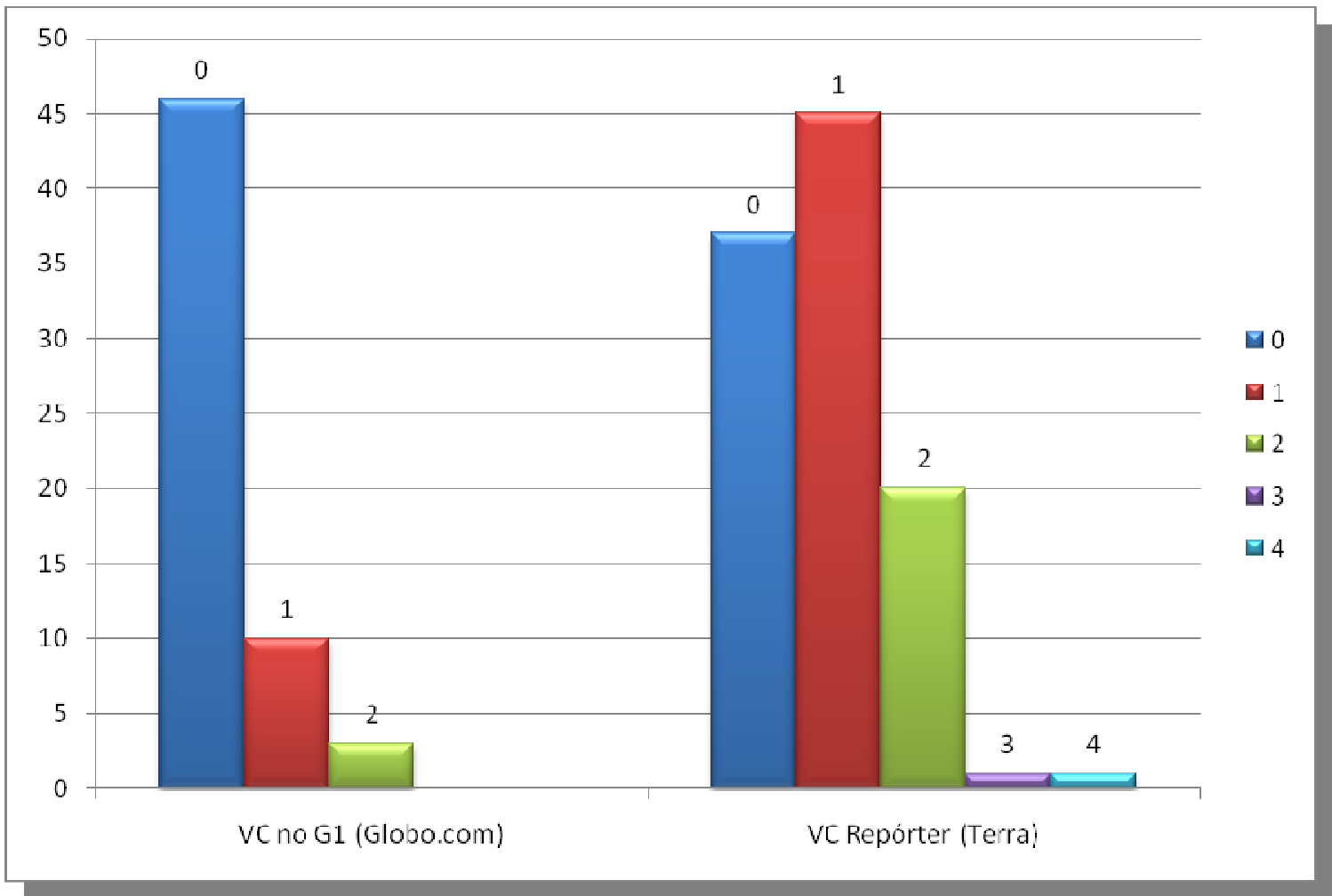

O serviço colaborativo do Terra demonstra combinar de forma mais fluente o trabalho do cidadão-repórter ao do jornalista. Além do número de fontes utilizadas, esta característica do VC Repórter pôde ser deduzida principalmente a partir de matérias sobre um mesmo tema, publicadas pelo mesmo autor nos dois veículos analisados. No VC Repórter, os dados originais são checados e enriquecidos, com inclusão de fontes locais, contextualização e busca por novas fontes. Exemplo são as matérias "Problema técnico atrasa trens e lota estações em SP"45, do VC Repórter, e "Atrasos de trens lotam estação

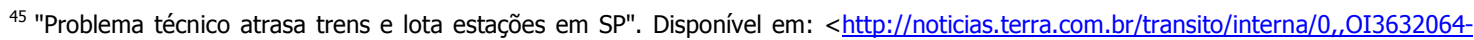
EI11777,00.html>. Acesso em: 20 mar. 2009. 
em São Paulo"46, do VC no G1, ambas publicadas no dia 13/03/2009. A primeira explica a causa do atraso, informa os horários de indisponibilidade e retorno e cita claramente a CPTM (Companhia Paulista de Trens Metropolitanos) como fonte. A segunda, em tom de relato, é pura descrição da experiência do cidadão-repórter. Possui três fotos (duas a mais que a primeira), mas nem por isso consegue ilustrar melhor o problema que virou notícia. Mizuta, do Terra, explica as preocupações que levam o serviço colaborativo do Terra a buscar enriquecer o conteúdo que chega à redação: "Sempre digo à equipe que não há matéria de uma fonte. Como no caso em que o trem atrasou —como posso confiar na pessoa que liga para a redação e diz que o trem levou $4 \mathrm{~h}$ para chegar? Ele pode estar querendo justificar um atraso no trabalho com uma notícia nossa."

Outro caso registrado no período de avaliação foi o das matérias "Carro cai em cratera na Zona Leste de SP"47, publicada pelo VC no G1 no dia 09/03/2009, e "Carro cai em buraco recém-fechado em SP"48, que foi ao ar no dia 11/03/2009 no VC Repórter. Sem creditar as informações, o site da Globo.com dá a impressão ao leitor de que o texto é apenas o relato do jornalista cidadão, sem "ouvir o outro lado", como prega por exemplo o Novo Manual da Redação, da Folha de S. Paulo (1992, p. 46). Além de prejudicar a credibilidade, a prática deixa de agregar à notícia informações úteis à sua compreensão, como a obtida pelo VC Repórter em contato com a Sabesp: a companhia afirmou que ressarciria o dono do veículo afetado. Um simples dado que expõe a resolução do conflito, torna o material mais informativo, e tende a estimular, no próprio público leitor e na comunidade de cidadãos-repórteres, a disciplina da verificação de informação tão necessária à prática do jornalismo, como defendem Kovach e Rosenstiel (2005). Opinião que é compartilhada por Rodrigo Flores, gerente geral de Notícias do UOL —desde que

\footnotetext{
46 "Atrasos de trens lotam estação em São Paulo". Disponível em: < http://g1.globo.com/VCnoG1/0,"MUL1041246-8491,00.html>. Acesso em: 20 mar. 2009

47 "Carro cai em cratera na Zona Leste de SP". Disponível em: < http://g1.globo.com/VCnoG1/0,_MUL1034505-8491,00.html>. Acesso em: 20 mar. 2009.

48 "Carro cai em buraco recém-fechado em SP". Disponível em: < http://noticias.terra.com.br/brasil//interna/0,_OI3628213EI8139,00.html>. Acesso em: 20 mar. 2009.
} 
assumiu o cargo, em 2006, Flores tem procurado aliar a participação do público ao jornalismo produzido pelo portal, ainda que o UOL não tenha um produto de colaboração estabelecido, como seus principais concorrentes. Para ele, o flagrante pode ser o início do processo jornalístico, mas não pode ser considerado o processo como um todo:

\begin{abstract}
"(...) acredito que o jornalismo envolve pauta, reportagem e edição. O flagrante é uma parte do jornalismo, é fundamental, ajuda muito, mas não sei se ele é jornalismo por não compreender todo o processo que define o jornalismo -isso justificaria a presença de uma moderação. Se você criar um site do seu bairro, até pode ser que você exista sem moderação. No nível de um grande portal como o UOL, isso seria impossível sem moderação."
\end{abstract}

A moderação pode evitar erros como o da publicação no VC Repórter, como notícia, de uma campanha de marketing viral. Em entrevista ao autor, Mizuta, do Terra, conta que em uma sexta-feira corrida, sob pressão, houve falha na apuração — dois leitores filmaram um fusca cortado ao meio que estava sendo rifado e enviaram ao site colaborativo. Segundo ela, houve falha de checagem de dados por parte da equipe, e de forma alguma o erro deve ser creditado ao fato de o VC Repórter adotar o jornalismo colaborativo: "(...) erramos por falha de apuração. Está aí o caso clássico do 'boimate' para provar que erros também acontecem no jornalismo tradicional. Não acho que o jornalismo colaborativo seja mais frágil, este controle precisa ser feito. É óbvio que vai haver erros. E por isso que há editores." 


\section{CIDADÃO-REPÓRTER, CIDADÃO-FONTE, CIDADÃO-PAUTEIRO}

Ao lado do baixo número de fontes citadas no decorrer das matérias publicadas pelos veículos colaborativos nos portais, o estudo também procurou avaliar se havia nos textos da amostra indícios claros de que fora o próprio colaborador a contatar as fontes, o que só ocorreu em 2,4\% (4) das matérias. Entre as fontes, duas matérias citam amigos dos cidadãos-repórteres, uma cita testemunha que preferiu não se identificar, e outra um técnico que aparentemente foi abordado pelo colaborador no local do acontecimento. Só $2,4 \%$ do jornalismo colaborativo dos portais brasileiros, portanto, pode ser comparado conceitualmente ao que propõem Gillmor (2004) e Bowman e Willis (2003) como jornalismo colaborativo, ao menos em seus graus mais avançados de engajamento.

O baixo comprometimento do interator, o usuário que participa do noticiário dos grandes portais brasileiros, leva-nos a acreditar que o jornalismo colaborativo ainda está em seus primeiros passos no Brasil e pouco atingiu o objetivo de democratizar a mídia, dar ao público verdadeiro poder sobre o noticiário, como apregoa Gillmor (2004, p. 137). Comparados aos níveis de participação de Bowman e Willis (2003), os dados obtidos pelo estudo indicam que o internauta brasileiro que participa dos serviços colaborativos ainda se concentra na atividade do registro flagrante, primeiro degrau de colaboração na escala do interator. A checagem dos fatos, a apuração complementar e o trabalho de edição verificado no noticiário open source ainda são objetivos a atingir.

Na maior parte das vezes, os serviços colaborativos representam apenas um canal adicional de recepção de informações, assim como uma simples fonte ou assessoria de imprensa. Em um segundo momento as informações são apuradas e complementadas pela redação, que the confere inclusive formato jornalístico -de acordo com o levantamento, 91\% (150) das matérias do corpus possuíam o formato de pirâmide invertida, que acompanha a linguagem jornalística desde o século 19 (PENA, 2005, p. 48). No VC Repórter, que possui mais intervenção da redação no material enviado pelos 
colaboradores, este índice sobe para 99\% (103 matérias), contra 75\% (47 matérias) do VC no G1. Este cenário evidencia o distanciamento do público em relação à atividade jornalística, e, em nossa visão, a necessidade de uma abordagem diferente por parte dos serviços de jornalismo colaborativo dos grandes portais, de forma a motivar o engajamento do público na descoberta e registro crítico e aprofundado de sua própria realidade. Pretendemos abordar alguns destes caminhos possíveis no próximo capítulo.

Outra evidência de que nos grandes portais brasileiros o cidadão-repórter pode ser considerado um "cidadão-fonte" é o uso de declarações do colaborador em aspas no decorrer do texto, em paralelo à citação de outras fontes, ou mesmo como a única fonte do texto —o que por si só já implica perda de credibilidade do material, conforme a própria opinião de Mizuta, do Terra, e também conforme conceituado no capítulo 2. A prática foi detectada com maior incidência no VC Repórter, do portal Terra, em matérias como "Zona norte de SP sofre com falta d'água"49. O texto aborda o drama do morador Cristiano Gregório — cujas declarações são citadas entre aspas, mas ao mesmo tempo assina o material - generalizando-o para todos os moradores do bairro, sem que houvesse apuração, nem por parte do colaborador, nem por parte da redação, de mais informações sobre o número de pessoas afetadas, ou uma estimativa de soluções de curto prazo por parte da companhia de saneamento básico do Estado. Outro caso foi a matéria "Defeito em novo CD do U2 decepciona fãs" ${ }^{50}$, também publicada pelo VC Repórter. O texto traz uma denúncia de um único colaborador — de que havia um problema no encarte do novo álbum da banda irlandesa-, neste caso confirmada pela gravadora Universal Music no Brasil. A verificação da denúncia com a outra parte envolvida garantiu, de um lado, a credibilidade da informação. Porém, ao utilizar frases do colaborador Everson Candido entre aspas no decorrer do texto, o VC Repórter coloca o

49 "Zona norte de SP sofre com falta d'água". Disponível em: < http://noticias.terra.com.br/brasil/interna/0,_0I3611091EI8139,00.html>. Acesso em: 13 mar. 2009.

50 "Defeito em novo CD do U2 decepciona fãs". Disponível em: <http://musica.terra.com.br/interna/0,OI3627901-EI1267,00.html>. Acesso em: 13 mar. 2009. 
usuário no papel de fonte, e não de autor do material. O estudo identificou na amostra pelo menos outros sete casos em que os colaboradores foram citados como fontes.

Erin Mizuta, editora do VC Repórter, do Terra, acredita que o internauta que participa dos sites de jornalismo colaborativo no Brasil encontra-se em uma fase intermediária entre cidadão-fonte e cidadão-repórter:

\begin{abstract}
"Ele não é apenas uma fonte, porque ele não é só a referência sobre determinado assunto, é também o principal interessado em ver outros lados. Nem é apenas um repórter, porque a matéria não pode ser construída com base no seu ponto de vista. Um repórter contratado para um meio de comunicação conta total credibilidade da empresa em seu relato. No caso do jornalismo colaborativo, não sei se um dia isso será possível. Como disse, todas as notícias partem, de um jeito ou outro, de interesses pessoais. (...) O cidadão-repórter transforma a função do jornalista. E eu acredito e concordo com isso. Se eles são os pauteiros/repórteres, cabe a nós sermos editores."
\end{abstract}

Sob esta óptica, o internauta que envia uma foto e um breve relato à redação dos portais pode também ser encarado como cidadão-pauteiro, espécie de "editor de planejamento, o primeiro homem a pensar no jornal do dia seguinte" (LAGE, 2001, p. 37). Rodrigo Flores, gerente geral de Notícias do UOL, tem visão semelhante:

"O jornalismo colaborativo está muito ligado ao processo de pauta. Embora o UOL não tenha canais abertos específicos para pautas, as pessoas usam todos os canais possíveis para nos pautar. E já fizemos inúmeras matérias com base nesse tipo de contato do público. Sem a pauta, a sugestão do público, o jornalismo fica muito mais difícil. A reportagem é a execução. A edição ainda fica por conta de nós jornalistas."

Para Caíque Severo, do iG, o tratamento que cada veículo dá a sua iniciativa de jornalismo colaborativo também ajuda a definir se a participação do usuário vai ser usada como fonte de informação ou notícia pronta. "Nessa decisão deve pesar uma avaliação de quantos participantes o veículo deseja ter, disse, em entrevista ao autor. Com isso, quanto mais rigoroso o critério editorial adotado pelo veículo ou mais amplo o recorte necessário a transformar um fato em notícia, menos espaço terá o conteúdo colaborativo. "Naturalmente vai existir muito mais gente que simplesmente criou um perfil em uma 
rede social do que aqueles que têm a capacidade e disposição de produzir qualquer conteúdo. É uma escadinha. Quanto mais complexa a participação, menos atores."

Se cidadão-repórter, cidadão-fonte ou cidadão-pauteiro, para Flores, do UOL, é uma questão semântica. Pelo menos na configuração que o UOL adota para absorver o conteúdo do público, a responsabilidade completa pela reportagem, segundo ele, não pode ser transferida para o internauta. Ela permanece nas mãos dos editores, jornalistas contratados que trabalham para o UOL:

\begin{abstract}
"Ele contribui para a reportagem, ele não é o repórter. Se você quiser chamá-lo de repórter eu também não me ofendo, porque volta e meia existe essa discussão. Acho que o jornalismo muito dificilmente é feito sem a participação do público, mesmo passivamente. $O$ que muda é que o cidadão passa a ser mais ativo diante deste processo. Também me sinto um pouco incomodado de não considerar o cidadão que contribui em casos como o que fizemos [durante as enchentes] em Santa Catarina, em que as pessoas mandaram fotos da tragédia e seis meses depois pedimos para elas retornarem ao local das fotos e mandarem as fotos dos lugares. Poxa, o internauta fez 0 trabalho todo, ele fez a reportagem para nós. (...) Mas posso chamá-lo de fonte? Difícil. Em alguns casos sim, mas em outros ele é co-autor. Isso depende do grau de participação. Quando ele contribui com um depoimento, ele é fonte, ele conta o que aconteceu. Mas quando ele vai até um local pautado por nós e produz uma foto, ele é co-autor. No caso de Santa Catarina, a pauta foi nossa, ele fez a reportagem e nós editamos - colocamos numa casca, pusemos uma legenda e publicamos."
\end{abstract}

A nosso estudo, no entanto, é válido classificar duas formas diferentes de participação: uma, mais ativa e coerente com práticas propostas por Bowman e Willis (2003) e Gillmor (2004), em que uma pessoa testemunha um fato, busca informações adicionais sobre ele (textos, fotos, vídeos, entrevistas), checa informações e cruza dados, enviando-o em seguida a um veículo de informação; outra, em que uma pessoa testemunha um fato e tão logo quanto possível envia um breve relato ou registro fotográfico ao veículo. $\mathrm{Na}$ primeira existe esforço de apuração e checagem de dados, o que aproxima a prática do leitor do jornalismo. Na segunda existe apenas o registro de um fato e sua transmissão ao canal de comunicação —o que exigiria outra denominação, que não a de cidadão-repórter, ao participante do noticiário. A seguir buscamos fazer uma proposta, de acordo com os níveis de participação de Bowman e Willis (2003) e Bruns (2005) apresentados anteriormente no capítulo 2. 
TABELA 8

Denominação do Participante no Jornalismo colaborativo

\begin{tabular}{|c|c|c|c|}
\hline Função do público & $\begin{array}{l}\text { Níveis de Participação } \\
\text { Bruns (2005) }\end{array}$ & $\begin{array}{l}\text { Níveis de Participação } \\
\text { Bowman e Willis (2003) }\end{array}$ & $\begin{array}{l}\text { Denominação do } \\
\text { participante }\end{array}$ \\
\hline \multirow{4}{*}{ Interator } & \multirow{3}{*}{$\begin{array}{l}\text { Noticiário Aberto Assistido } \\
\text { pelo Editor }\end{array}$} & Registro Flagrante & $\begin{array}{l}\text { Cidadão-fonte ou } \\
\text { Cidadão-pauteiro }\end{array}$ \\
\hline & & Checagem de Fatos & \multirow{3}{*}{ Cidadão-repórter } \\
\hline & & Apuração complementar & \\
\hline & Noticiário Aberto & Notícias Open Source & \\
\hline
\end{tabular}

INVESTIGAÇÃO, DIVULGAÇÃO, CREDIBILIDADE

Seja ele cidadão-fonte ou cidadão-repórter, o interator que participa do noticiário dos grandes portais tem outro desafio constante: o da credibilidade. Conforme os critérios do discurso jornalístico abordados no capítulo 2, a apuração e o cruzamento de informações entre fontes é fundamental para conferir credibilidade ao texto jornalístico:

\footnotetext{
"Toda boa reportagem exige cruzamento de informações. Esse mecanismo jornalístico consiste em, a partir de um fato transmitido por uma determinada fonte, ouvir a versão sobre o mesmo fato de outras fontes independentes. O recurso é útil tanto para comprovar a veracidade de uma notícia quanto para enriquecer a reportagem com aspectos não formulados pela fonte original." (MANUAL DA REDAÇÃO: FOLHA DE S.PAULO, 2006, p. 26)
}

Deste ponto de vista, o relato pessoal sobre uma experiência torna-se insuficiente para fazer de um texto crível por si só, sem que haja um maior trabalho de apuração por parte das redações dos veículos. Para esta inferência, contribuíram tanto o cidadãorepórter —que em geral não se preocupou em procurar fontes de informação ou explicitar técnicas de apuração utilizadas, o que traçaria ao menos os limites da informação- 
quanto os portais Terra e Globo.com, cujos serviços participativos não possuem perfis dos jornalistas cidadãos, nem mecanismos de pontuação ou algoritmos sociais -como tempo de participação, registros de navegação- que permitam ao leitor conhecer e avaliar por conta própria se o autor do material possui credibilidade anterior ou algum grau de distanciamento dos temas abordados para tratá-los com imparcialidade.

\begin{abstract}
"Os algoritmos sociais não servem apenas para avaliar a performance dos participantes, eles também qualificam a relevância do conteúdo publicado. A medição da performance do conteúdo pode ser estimada a partir dos seguintes elementos: número de acessos, de comentários relacionados, de notificações enviadas por e-mail para que outras pessoas acessem, de recomendação de usuários com boa performance, entre outros. Esses dados servem para o sistema avaliar, por exemplo, se um vídeo postado como 'muito engraçado' tem realmente essa característica. Se foi assistido muitas vezes e os usuários tiverem publicado comentários e enviado recomendações por e-mail, é sinal de que essas pessoas aprovaram o conteúdo." (SPYER, 2007, p. 78).
\end{abstract}

Este vácuo de credibilidade criado entre cidadão-repórter e veículo abre espaço, segundo a análise dos dados, para a possível veiculação de material de divulgação no noticiário. Um exemplo do qual é possível inferir a hipótese são as matérias "Dia Internacional da Mulher agita o centro de São Paulo"51, publicada em 09/03/2009 pelo VC no G1, e "Mulheres têm serviços gratuitos no seu dia"52, publicada em 10/03/2009 pelo VC Repórter, ambas com autoria do internauta Cristiano dos Santos. "Segundo os organizadores, aproximadamente 8.000 pessoas passaram pelo evento durante o sábado. E a expectativa era de até 15.000 visitantes nesse domingo", diz o texto, sem clarificar se os organizadores foram ouvidos por Cristiano ou pela reportagem dos veículos. O que impede que o autor seja ele mesmo integrante da organização do evento, e tenha se utilizado do discurso jornalístico para divulgá-lo? Quão envolvido com o fato relatado está o autor? Caso ele faça realmente parte da organização do evento, quais são as implicações da acolhida de seu texto em um serviço de jornalismo colaborativo? Bastaria,

\footnotetext{
51 "Dia Internacional da Mulher agita o centro de São Paulo". Disponível em: <http://g1.globo.com/VCnoG1/0,MUL1034520$\underline{8491,00 . h t m l}>$. Acesso em: 13 mar. 2009.

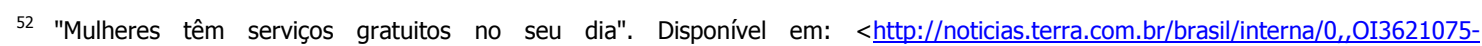
EI306,00.html>. Acesso em: 13 mar. 2009.
} 
neste caso, a simples checagem dos fatos pela equipe de jornalistas moderadores? 0 quanto esta prática abala a credibilidade do texto? Para Rodrigo Flores, gerente geral de notícias do UOL, o jornalismo online está mais maduro e preparado para evitar fraudes em relação a conteúdo enviado pelo usuário, mas não imune a elas.

\begin{abstract}
"Poderia sim voltar a acontecer. Se você se dispõe a adotar este recurso de colaboração em um portal do tamanho do UOL, é muito difícil estabelecer os filtros necessários para evitar uma fraude. 0 risco da mentira está presente a todo momento. A partir do momento em que você registra uma entrevista de alguém, você corre esse risco. 'Eu vi o avião cair', mas não viu. O desafio do jornalismo é tentar chegar perto do risco zero."
\end{abstract}

Outro trecho do texto publicado pelo VC no G1 também deixa a impressão de que o site pode ter acolhido material de divulgação: "A atração que mais chamava atenção eram duas garotas segurando uma placa no meio da multidão, onde estava escrita a frase: 'Troco sonhos'. As mulheres, após dizerem para essas garotas quais eram os seus sonhos, ganhavam um bombom Sonho de Valsa." Ao publicar um simples relato pessoal sobre um evento, sem clarificar que as fontes de informação citadas foram checadas e/ou apuradas pela própria redação, e também sem conhecer o perfil do autor e estar certo de que ele não trabalha para a fabricante da marca de bombons —nem outra empresa coligada—, é impossível excluir a hipótese de que o site de jornalismo participativo da Globo.com tenha feito divulgação espontânea da marca de chocolates.

Casos não faltam em que os veículos analisados publicam relatos pessoais sobre um evento ou textos com ar de divulgação, especialmente em matérias na área de Cultura/ Entretenimento. É o caso das matérias "Larissa Costa é eleita a nova Miss RN"153 (VC no G1), "Peça mostra fim da escravidão em Porto Alegre"54 (VC Repórter) e "Grupo caribenho

\footnotetext{
53 "Larissa Costa é eleita a nova Miss RN". Disponível em: <http://g1.globo.com/VCnoG1/0,„MUL1040266-8491,00.html>. Acesso em: 13 mar. 2009.

54 "Peça mostra fim da escravidão em Porto Alegre". Disponível em: < http://diversao.terra.com.br/interna/0,OI3626002EI1539,00.html>. Acesso em: 13 mar. 2009.
} 
Florida Memorial Steelband toca em Salvador"155 (VC no G1). A mera descrição factual, somada ao registro fotográfico, confere ao material característica de testemunho, o que novamente abala a credibilidade pela ausência de verificação e citação de outras fontes. Porém, no contexto do jornalismo colaborativo, esta credibilidade não é automaticamente conferida ao material pela marca ou pela redação do veículo, e deve ser conferida ao material pela checagem por parte dos jornalistas que moderam o serviço. Ou pelo próprio leitor, em conjunto com o jornalista cidadão, na medida em que o primeiro seja capaz de avaliar o perfil e as credenciais do último, desvinculando-o do fato apurado em benefício da isenção, e também capaz de avaliar o método de apuração utilizado, para só então decidir se o material é crível ou não. No caso dos sites analisados, nenhuma das duas hipóteses é comunicada com clareza ao leitor, o que tende a abalar a credibilidade dos serviços de colaboração dos grandes portais. Para Márion Strecker, diretora de conteúdo do UOL, este é um dos principais calcanhares de Aquiles do jornalismo colaborativo:

\begin{abstract}
"Essa questão que me arrepia, criar um veículo em que jornalistas não fazem jornalismo, mas apenas recebem e rechecam material externo, enviado por pessoas não treinadas, sem capacitação para isso - o custo de um jornalista checar devidamente um texto externo pode ser tão alto ou maior do que 0 custo de produzir um texto original, uma reportagem original. Claro que depende do grau de ambição de qualidade desse veículo - quanto mais alta a ambição, mais alto o custo de produção. Então se o assunto é só o buraco de rua, tudo bem. Mas se o assunto é investigar um crime de colarinho branco, para citar dois extremos, a coisa se complica."
\end{abstract}

Strecker questiona se o jornalismo colaborativo não é uma maneira de baratear os custos de produção do jornalismo por forças de mercado que hoje concorrem com os veículos de mídia tradicionais. "Quem não conhece ou não valoriza o bom jornalismo acha quimérica a possibilidade de fazer jornalismo sem jornalistas. Afinal não é o que o Google tanta fazer com o Google News? Será que o Google pensa nos objetivos ou por quem os veículos que ele exibe estão sendo guiados?"

55 "Grupo caribenho Florida Memorial Steelband toca em Salvador". Disponível em: <http://g1.globo.com/VCnoG1/0 „MUL10414738491,00.html >. Acesso em: 13 mar. 2009. 
Lemos, do Overmundo, é mais taxativo. Para ele, em alguns casos o jornalismo colaborativo é sim uma forma de baratear custos de produção. "Uma das lições que aprendemos com o Overmundo é que a rede e a colaboração faz muito por você, mas não faz tudo. Será sempre necessário ter uma equipe de moderação, edição ou interação, por menor que ela seja." Ele concorda com Strecker, no entanto, ao considerar caro o processo jornalístico que se aprofunda na apuração e na reportagem:

\footnotetext{
"Inevitavelmente o jornalismo colaborativo vai transformar o jornalismo tradicional. Mas cada vez mais há a percepção de que a ideia de jornalismo tradicional é um bem público, por questões que envolvem reputação e recursos. O jornalismo investigativo, por exemplo, é caríssimo de ser feito e não há como negar que ele tenha uma função importantíssima. Acho que o futuro se definirá no processo de equilíbrio, em que o jornalismo colaborativo amplia as fronteiras da ideia de jornalismo."
}

Assim como ele, Flores, do UOL, Mizuta, do Terra, e Severo, do iG, acreditam que a colaboração do público na construção do noticiário é uma tendência impossível de reverter. Como então equilibrá-la e fomentar uma participação mais engajada do público brasileiro, sem ferir o bom jornalismo? 


\section{CONCLUSÃO}

A consolidação do jornalismo colaborativo ainda depende de um longo caminho no Brasil, ligado principalmente ao despertar do engajamento do (antigo) público com sua realidade, sua necessidade informativa, a necessidade de conhecimento sobre a própria realidade para então, vendo seu reflexo, enxergar-se capaz de transformá-la.

Nosso estudo conseguiu identificar o baixo comprometimento do interator com o noticiário dos grandes portais brasileiros, com o processo jornalístico como um todo. Se considerarmos a evolução da colaboração segundo os níveis de participação de Bowman e Willis (2003) e Bruns (2005), o internauta brasileiro, que predominantemente envia breves registros flagrantes da realidade aos grandes portais, está, ao menos nestes ambientes, no primeiro degrau da escala do interator. Visão consoante com a impressão de Erin Mizuta, editora do VC Repórter:

\footnotetext{
"Os brasileiros ainda não estão familiarizados com o conceito do jornalismo colaborativo -e também de jornalismo, principalmente na Internet. Aos poucos, eles estão descobrindo que a foto postada no Orkut e que fez tanto sucesso porque mostra o dia-a-dia de quem sofreu com uma cheia, por exemplo, pode virar (e é) uma notícia. Ou que o problema que atinge o bairro, e que vira tema de debate em uma comunidade, pode ser cobrado das autoridades por uma matéria de denúncia." 56
}

Ainda falta ao internauta brasileiro dos grandes portais de conteúdo compreender e praticar a checagem dos fatos, realizar a apuração complementar de dados e eventualmente até conferir ao material edição jornalística —embora, para tanto, seja preciso que os veículos em questão também possuam plataformas e pontos de vista mais abertos que os atuais para o envio e edição de conteúdos por parte do (antigo) público -

\footnotetext{
${ }^{56}$ Em entrevista ao autor.
} 
que só então poderá, nestes contextos, receber precisamente o título de cidadão-repórter.

O que é pouco provável que aconteça, na visão de Rodrigo Flores, do UOL:

\begin{abstract}
"Temos usado o jornalismo colaborativo no UOL, o Jornal Nacional todo dia tem exibido alguma coisa do público. Então depende do modelo que você considera para dizer que está dando certo ou não. No meu entendimento o fenômeno é crescente, e temos que usar cada vez mais. Mas não creio que vamos usar [na grande imprensa] modelos muito puros, que acreditam exclusivamente na autoregulação." ${ }^{157}$
\end{abstract}

A preocupação de Flores parece ser a de relegar ao (antigo) público um trabalho que é do jornalista. Márion Strecker, diretora de conteúdo do UOL, mostra ponto de vista semelhante ao situar a colaboração como companheira inseparável do jornalismo, desde as origens do próprio jornal impresso —porém, sem considerar um papel ativo do público diante do processo jornalístico em si:

"O público sempre participa e sempre participou em alguma medida do noticiário. Os jornais, esse veículo do século 19, sempre tiveram em certa medida a colaboração do leitor, expressa em seção de cartas, em críticas para ombudsman, repórteres sempre foram às ruas e tiveram contato direto com o público e aprenderam alguma coisa com isso. (...) Entre ter o público como personagem e têlo como autor, há um amplo espectro de atividades, que podem e são exploradas. Por exemplo, você pode ter uma repórter do UOL, a Daniela Paixão, saindo com um cinegrafista e ouvindo pessoas na rua. Ou você pode ter depoimentos de pessoas, feitos em vídeo, elas mesmo se filmando, enviadas espontaneamente ou por estímulo do portal. Isso tudo o UOL utiliza cotidianamente. Estou dando alguns exemplos bem clássicos, só para explicar que, na minha visão, não existe uma linha divisória muito definida entre 0 jornalismo colaborativo e o não colaborativo, porque a gente vive em sociedade, e o nosso jornalismo trata de questões sociais, ele é feito para a sociedade e sobre a sociedade. O jornalismo não-colaborativo seria o quê? O jornalismo ditatorial, imperial, divino?"2

O questionamento de Strecker revela, nas entrelinhas, o posicionamento dos veículos de comunicação para a manutenção da legitimidade social do jornalismo tradicional, visão que parece entrar em confronto com novos modelos de comunicação em rede propostos pela Internet. Bruns (2005) consegue mapear o fenômeno com precisão quando propõe a superação do modelo de gatekeeping, tão familiar à prática jornalística, pelo de gatewatching, que coloca a imprensa como nó em uma rede de relações entre

\footnotetext{
${ }^{57}$ Em entrevista ao autor
} 
acontecimentos, fontes, leitores, colaboradores -e não como centro para onde sempre convergem as informações, como vimos nas definições de Bowman e Willis (2003) apresentadas no capítulo 2. Além disso, casos que recentemente ganharam repercussão entre jornalistas ajudam a compreender o fim deste "absolutismo" da imprensa polêmica envolvendo o blog "Fatos e Dados", criado pela área de comunicação da Petrobras em maio de 2009, para publicar informações sobre a CPI (Comissão Parlamentar de Inquérito) instaurada no mesmo mês para investigar supostas fraudes da estatal e também publicar respostas da empresa aos veículos que começaram a cobrir as investigações $^{58}$; e os protestos da população iraniana divulgados pelo Youtube após a polêmica eleição de junho de 2009, que reelegeu Mahmoud Ahmadinejad ${ }^{59}$.

No primeiro caso, a Petrobras decidiu divulgar em um blog as respostas às questões feitas por jornalistas à empresa, mesmo antes que as matérias fossem publicadas. A abertura destas informações gerou fortes críticas por parte de jornais como Folha de S.Paulo, O Estado de S.Paulo e O Globo, além da ANJ (Associação Nacional de Jornais), para quem a estatal estaria tentando intimidar a imprensa desrespeitando a confidencialidade que orienta jornalistas na relação com suas fontes. Não há, porém, ética estabelecida no caminho contrário. E com a Internet a imprensa não é mais o único canal disponível para fazer sua voz chegar ao público - a reação dos jornais talvez tenha sido mais contra este fenômeno de nosso tempo do que contra a Petrobras em si.

No caso das eleições no Irã, vídeos feitos por cidadãos registrando os protestos que eclodiram em Teerã e por todo o país começaram a aparecer no Youtube após o dia 12 de junho de 2009, quando Ahmadinejad foi reeleito no primeiro turno em um cenário de dúvidas sobre fraudes na apuração. Mesmo redes como a CNN, da imprensa ocidental dita "liberal" —em contraste à imprensa iraniana, supostamente sob censura do Estado—,

\footnotetext{
${ }^{58}$ Blog da Petrobras opõe visões sobre transparência e jornalismo. Disponível em: <http://www.direitoacomunicacao.org.br/ content.php?option=com content\&task=view\&id=5106>. Acesso em: 12 ago. 2009

${ }^{59}$ Internet noticia acontecimentos do Irã e bate imprensa tradicional. Disponível em: < http://www.geek.com.br/posts/10222-internetnoticia-acontecimentos-do-ira-e-bate-imprensa-tradicional>. Acesso em: 15 jun. 2009
} 
não foram capazes de mostrar a tensão e a violência nas ruas do país de forma tão rápida quanto o Youtube, o Twitter, enfim, os repositórios de conteúdo gerado pelo usuário (UGC). Mais uma vez a informação dispensou a imprensa para circular.

Como o jornalismo deve encarar este novo cenário? Será que a Internet e a colaboração vão acabar com o jornalismo e os jornalistas? "Não existe uma disputa entre tipos de jornalismo. Ou uma coisa é notícia ou não é. E o critério do que é notícia tem vários níveis e cada leitor escolhe os filtros que deseja usar para chegar ao que ele considera notícia", acredita Caíque Severo, do iG. Ronaldo Lemos, do Overmundo, acredita em um futuro de equilíbrio entre o jornalismo tradicional e o colaborativo:

\footnotetext{
"Inevitavelmente o jornalismo colaborativo vai transformar o jornalismo tradicional. Mas cada vez mais há a percepção de que a ideia de jornalismo tradicional é um bem público, por questões que envolvem reputação e recursos. 0 jornalismo investigativo, por exemplo, é caríssimo de ser feito e não há como negar que ele tenha uma função importantíssima. Acho que o futuro se definirá no processo de equilíbrio, em que o jornalismo colaborativo amplia as fronteiras da ideia de jornalismo, mas há uma percepção de que ter partes centralizadas da prática de jornalismo também é importante."
}

Casos como o do blog da Petrobras e as eleições iranianas são evidencias claras de que é necessário ao jornalismo buscar uma nova posição no cenário midiático, quiçá no cenário social. Se, por um lado, vozes sociais antes dependentes da mídia para chegar ao público começam a emergir à revelia da imprensa, de outro ponto de vista a sociedade continua a relegar à categoria de profissionais conhecida como jornalistas o trabalho de localizar, em meio ao mar de informações diárias, submersas ou aparentes, o que é ou não importante, o que merece ser investigado e trazido à luz. Numa espécie de "contrato social", como o de Rosseau, o cidadão parece abrir mão do engajamento informativo para que exista a mídia, assim como abre mão de sua liberdade para que surjam as leis, o Estado, a sociedade em si. Pensar nesta nova posição do jornalismo e dos jornalistas perante o novo cenário colaborativo exige pois, em nosso ponto de vista, a formulação e 
a execução de um novo "contrato midiático", capaz de envolver o público e a mídia e que seja legitimado pelo próprio envolvimento coletivo.

Inevitável que este novo acordo informativo passe pela conscientização do (antigo) público sobre seu papel no conhecimento e na transformação da própria realidade. Para Márion Strecker, do UOL:

\begin{abstract}
"O problema no Brasil é a falta de consciência de cidadania. Acho que essa é a razão de o jornalismo colaborativo não dar certo por aqui. $\mathrm{O}$ cidadão raras vezes se sente dono da sua cidade, tem a consciência do quanto imposto ele paga, e do quanto ele pode cobrar dos nossos governantes. Ninguém lembra em quem votou para deputado, para prefeito na última eleição. A atividade política é baixa, associações de bairros são poucas. $O$ engajamento social é alto, mas o político é muito baixo. Se o voto não fosse obrigatório no Brasil, a quantidade de pessoas que votam cairia drasticamente. As pessoas não leem os programas, não vão às convenções, pedem santinho para colar voto no dia da eleição porque o voto é obrigatório. Então falta consciência dos próprios direitos, falta cobrança, com isso falta motivo para exercer uma atividade jornalística que deve ser essencialmente crítica. Porque se não é crítica, não é jornalismo, é propaganda."
\end{abstract}

Erin Mizuta, do Terra, acredita que a tendência é haver maior participação de atores sociais no que é publicado pela imprensa, e a evolução do estado atual do jornalismo colaborativo no Brasil também depende de uma maior consciência social:

\begin{abstract}
"Acredito que ela exige uma mudança não só no jornalismo colaborativo, mas na educação em geral, na consciência social, política e até jurídica das pessoas, até para que elas saibam o que pode acontecer se elas publicarem uma notícia falsa. (...) Para que você quer uma nação inteira de jornalistas? É utópico. É o fim do jornalismo. Haverá sim, mais colaboração de quem participa dos acontecimentos. Mas isso não será o fim, só uma mudança."
\end{abstract}

Uma das vias possíveis para a conscientização do (antigo) público "oprimido" pela mídia de massa pode ser o resgate da função educativa do jornalismo -e, em nosso intuito de apontar caminhos para estudos futuros, pretendemos aqui traçar um paralelo entre as vocações do jornalismo colaborativo e a Pedagogia do Oprimido de Paulo Freire. 


\title{
JORNALISMO DO OPRIMIDO
}

Em um contexto de décadas de convívio com a mídia de massa -tida como opressora do ponto de vista do aumento de capacidade expressiva promovido pela Internet, de acordo com Shirky (2008, p. 106)-, baixa penetração da Internet e baixo grau de alfabetização de sua população -o Brasil ocupa o $62^{\circ}$ lugar no ranking de alfabetização da $\mathrm{ONU}^{60}$-, o brasileiro torna-se alguém pouco ou nunca antes convidado à prática da verdadeira autonomia midiática. Não a autonomia que decorre do simples acesso à rede, mas uma autonomia libertadora, capaz de inseri-lo no processo histórico, como sujeito, abrindo caminho à busca da afirmação (FREIRE, 2005, p. 24).

Esta óptica traz à tona diversas ressonâncias entre os propósitos do jornalismo colaborativo e a Pedagogia do Oprimido, segundo a qual "ninguém liberta ninguém, ninguém se liberta sozinho" (FREIRE, 2005, p. 58), mas os homens se libertam em comunhão. Em primeiro lugar, é possível comparar a mídia de massa à pedagogia tradicional por sua vocação em "depositar" ideias em seu público, o que Freire chama de "concepção bancária". Diz o autor:

\begin{abstract}
"Quanto mais analisamos as relações educador-educandos, na escola, em qualquer de seus níveis (ou fora dela), parece que mais nos podemos convencer de que estas relações apresentam um caráter especial e marcante -o de serem relações fundamentalmente narradoras, dissertadoras. (...) Falar da realidade como algo parado, estático, compartimentado e bem-comportado, quando não falar ou dissertar sobre algo completamente alheio à experiência existencial dos educandos vem sendo, realmente, a suprema inquietação desta educação. A sua irrefreada ânsia. Nela, o educador aparece como seu indiscutível agente, como o seu real sujeito, cuja tarefa indeclinável é 'encher' os educandos com conteúdos de sua narração. Conteúdos que são retalhos da realidade desconectados da totalidade em que se engendram e em cuja visão ganhariam significação. A palavra, nessas dissertações, se esvazia da dimensão concreta que devia ter ou se transforma em palavra oca, em verbosidade alienada e alienante. Daí que seja mais som que significação e, assim, melhor seria não dizê-la. Por isto mesmo é que uma das características desta educação dissertadora é a 'sonoridade' da palavra e não sua força transformadora." (FREIRE, 2005, p. 65)
\end{abstract}

60 United Nations Statistics Division. Indicators on literacy, Jun/09. Disponível em: < $\underline{\text { http://unstats.un.org/unsd/demographic/ }}$ products/socind/literacy.htm>. Acesso em 12 ago. 2009. 
Seis anos depois de nossa graduação na Escola de Comunicações e Artes da Universidade de São Paulo, e dez anos após ter iniciado nossa carreira em um grande jornal diário da capital paulista, podemos precisar que foi esta a exata sensação que tivemos em relação ao jornalismo. Atividade em grande parte "dissertadora", em muitos momentos distante do público - a maior parte do material produzido nas redações parte de contatos telefônicos ou via e-mail com órgãos oficiais ou instituições; o processo de inclusão de personagens está mais próximo da busca de alguém que se encaixe na própria teoria que na descoberta do novo, do diferente. Palavras sonoras, mas pouco transformadoras. E o distanciamento só se acentua quando consideramos a extrema dependência dos veículos nacionais em relação ao agendamento global de informações — que ocorre notadamente por influência de agências internacionais de notícias como Agence France Presse, Associated Press, EFE e Reuters, para citar apenas algumas. Como relata Moreira (1996, p. 23), "a despeito das diferenças e distâncias econômicas, políticas e culturais [em relação a seus países de origem], as agências internacionais fornecem mais de $70 \%$ de tudo que se ouve, lê ou vê sobre o mundo no Brasil".

Isso reforça ainda mais no público leitor a sensação de estrangeiro identificada por Sérgio Buarque de Holanda na alma do brasileiro, como veremos adiante. E distancia-o da transformação social, que exige de qualquer força que procure liderá-la um testemunho ligado à ação cultural e à experiência histórica/existencial de uma população que deseja libertar-se. Segundo Freire (2005, p. 203): "Sendo históricas estas dimensões do testemunho, o dialógico, que é dialético, não pode importá-las simplesmente de outros contextos sem uma prévia análise do seu. A não ser assim, absolutiza o relativo e, mitificando-o, não pode escapar à alienação." Em seu "Educação como Prática da Liberdade", Freire fala um pouco de como a mídia, como estabelecida no Brasil, contribui para este processo: 


\begin{abstract}
"Excluído da órbita das decisões, cada vez mais adstritas a pequenas minorias, [o brasileiro] é comandado pelos meios de publicidade, a tal ponto que, em nada confia ou acredita se não ouviu no rádio, na televisão ou se não leu nos jornais. Daí a sua identificação com formas míticas de explicação do seu mundo. Seu comportamento é o do homem que perde dolorosamente o seu endereço. É o homem desenraizado. Sentíamos, igualmente, que estava a nossa democracia em aprendizagem, sob certo aspecto, o histórico-cultural, fortemente marcada por descompassos nascidos de nossa inexperiência do autogoverno. Por outro, ameaçada pelo risco de não ultrapassar a transitividade ingênua, a que não seria capaz de oferecer ao homem brasileiro, nitidamente, a apropriação do sentido altamente mutável de sua sociedade e do seu tempo. Mais ainda, não the daria, o que é pior, a conviç̧ão de que participava das mudanças de sua sociedade. Convicção indispensável ao desenvolvimento da democracia." (FREIRE, 2008, p. 98)
\end{abstract}

E o autor prossegue, falando sobre o processo pedagógico e sobre o caminho que 0 analfabeto percorre da escuridão iletrada ao domínio da língua:

\begin{abstract}
"O analfabeto aprende criticamente a necessidade de aprender a ler e a escrever. Prepara-se para ser o agente deste aprendizado. E consegue fazê-lo, na medida mesma em que a alfabetização é mais do que o simples domínio psicológico e mecânico de técnicas de escrever e ler. É o domínio dessas técnicas em termos conscientes. É entender o que se lê e escrever o que se entende. É comunicar-se graficamente. É uma incorporação. Implica não uma memorização visual e mecânica de sentenças, de palavras, de sílabas, desgarradas de um universo existencial —coisas mortas ou semimortas- mas uma atitude de criação e recriação. Implica numa autoformação de que possa resultar uma postura interferente do homem sobre seu contexto." (FREIRE, 2008, p. 119)
\end{abstract}

O analfabeto, em nossa metáfora que tenta paralelizar a obra de Paulo Freire aos objetivos do jornalismo colaborativo, seria aquele que não tem acesso à imprensa —mais do que isso, pois, segundo Freire, o mero domínio psicológico e mecânico da língua não basta à real alfabetização, como, para nós, o simples acesso ao noticiário e até mesmo sua discussão em círculos sociais não implica real domínio sobre a mídia. O simples consumo de informação sem uma relação direta desta informação com a transformação da própria realidade passa a ser palavrório vazio, brincadeira de jogral, repetição mecânica de palavras e mensagens. Não gera a postura interferente do homem sobre seu contexto —o que não contribui para conectar o brasileiro à sua própria realidade, pelo contrário.

Freire enxerga num processo que chama de prescrição um dos maiores obstáculos à libertação e uma das causas da criação de uma situação opressor-oprimido. Quando prescreve uma ideia, uma teoria, o educador -e, por que não, também o jornalista- 
impõe uma visão de mundo a outra consciência. Ação alienante, segundo Freire, capaz de transformar a consciência receptora em uma "consciência hospedeira" da consciência opressora. "Por isso, o comportamento dos oprimidos é um comportamento prescrito. Faz-se à base de pautas estranhas a eles -as pautas dos opressores":

\begin{abstract}
"Os oprimidos, que introjetam a 'sombra' dos opressores e seguem suas pautas, temem a liberdade, na medida em que esta, implicando a expulsão desta sombra, exigiria deles que 'preenchessem' o 'vazio' deixado pela expulsão com outro 'conteúdo' —o de sua autonomia. O de sua responsabilidade, sem o que não seriam livres. A liberdade, que é uma conquista, e não uma doação, exige uma permanente busca. Busca permanente que só existe no ato responsável de quem a faz. Ninguém tem liberdade para ser livre: pelo contrário, luta por ela precisamente porque não a tem. Não é também a liberdade um ponto ideal, fora dos homens, ao qual inclusive eles se alienam. Não é ideia que se faça mito. É condição indispensável ao movimento de busca em que estão inscritos os homens como seres inconclusos." (FREIRE, 2005, p. 37)
\end{abstract}

Para Freire, a pedagogia do oprimido tem suas raízes na inserção crítica das pessoas em sua realidade, na ação prática de homens empenhando-se por sua libertação. Ao ser uma forma de reconectar a pessoa à sua realidade, ao seu contexto, ao seu entorno, enxergamos no jornalismo colaborativo o "jornalismo do oprimido", uma forma de reinserir o (antigo) público de forma crítica em sua realidade, da qual muitas vezes se vê afastado pela atitude que a imprensa em geral, e os grandes portais de Internet em particular, tomam em relação ao noticiário, como antes exposto.

O primeiro passo para este processo de libertação ter início, porém, é o "oprimido" consientizar-se de sua situação concreta. Esta descoberta de si mesmo, no entanto, é dificultada exatamente pela prescrição, que aloca no "oprimido" o próprio "opressor":

"[Uma das estruturas da dominação] é a dualidade existencial dos oprimidos que, 'hospedando' o opressor, cuja 'sombra' eles 'introjetam', são eles e ao mesmo tempo são o outro. Daí que, quase sempre, enquanto não chegam a localizar o opressor concretamente, como também enquanto não cheguem a ser 'consciência para si', assumam atitudes fatalistas em face da situação concreta de opressão em que estão. (...) De tanto ouvirem de si mesmos que são incapazes, que não sabem nada, que não podem saber, que são enfermos, indolentes, que não produzem em virtude de tudo isto, terminam por se convencer de sua 'incapacidade'. Falam de si como os que não sabem e do 'doutor' como o que sabe e a quem devem escutar. Os critérios de saber que lhe são impostos são os convencinais. (...) Até o momento em que os oprimidos não tomem consciência das razões de seu estado de opressão 'aceitam' de forma fatalista sua exploração. Mais ainda, provavelmente assumam posições passivas, alheadas, com relação à necessidade de sua própria luta pela conquista da liberdade e de sua afirmação no mundo. Nisto reside sua 'conivência' com o regime opressor." (FREIRE, 2005, p. 54) 
A nós parece gritante a semelhança do processo de dominação pela educação descrito por Freire com a atitude que a imprensa em geral toma face a seu público. Cada vinheta comercial de revista ou jornal que prescreve ao público a necessidade de estar informado carrega em si a mensagem de que este mesmo público está desinformado. A pergunta que normalmente não lhe segue o raciocínio é —o que é informação? O tipo de noticiário poubelle ${ }^{61}$, sobre celebridades, que cada vez mais toma conta das home pages dos principais portais brasileiros? A numeralha econômica intraduzível, legível somente por algumas dezenas de milhares de investidores? O escândalo deste ou daquele político em Brasília, que por toda a conformação do processo democrático brasileiro parece tão distante de minha realidade quanto a própria capital, encravada no Planalto Central? Tudo isso pode ser informação, notícia. Mas onde a informação sobre meu bairro, sobre minha cidade, sobre meu entorno? Onde a discussão sobre a violência que atinge minha região? Onde a crítica à falta de acesso à educação, saneamento, saúde em minha vizinhança? Onde, enfim, o tipo de fato concreto capaz de me levar a uma conscientização crítica sobre minha realidade e à possível ação sobre ela? Basta ler a revista semanal de maior circulação no país para estar realmente informado e capaz de transformar seu entorno?

\footnotetext{
"As ideias das classes dominantes tendem a ser as ideias dominantes (proposição que, com nossa nova compreensão de linguagem e de seu funcionamento, poderíamos considerar pleonástica). Por pelo menos 200 anos foram os administradores das empresas capitalistas que dominaram o mundo -isto é, separaram o factível do implausível, o racional do irracional, o sensato do insano, e de outras formas ainda determinaram e circunscreveram a gama de alternativas dentro das quais confinar as trajetórias da vida humana. Era, portanto, sua visão do mundo, em conjunto com o próprio mundo, formado e reformado à imagem dessa visão, que alimentava e dava substância ao discurso dominante." (BAUMAN, 2000, p. 66)
}

\footnotetext{
${ }^{61}$ Ignácio Ramonet, diretor do Le Monde Diplomatique, faz uma crítica ao tipo de imprensa poubelle que se ocupa de celebridades - e mesmo à grande imprensa, que desde a morte de Lady Di passou a ocupar-se do mundo das celebridades como forma de vender jornais. "Os paparazzi não são mais do que o resultado da situação geral da mídia, uma situação dominada pelo mercado e pelo lucro. 'Há uma realidade do mercado', conforma Jean-François Leroy, fotojornalista que, desde 1989, dirige a prestigiada manifestação 'Visa pour l'image', de Perpignan. 'Quando Paris-match faz sua cobertura sobre François Mittérrand em visita a Sarajevo, vende muito menos do que quando sua manchete é sobre a morte de um animador de programas de TV, como Patrick Leroy: 1,8 milhão de exemplares. (...) Quando perguntávamos aos nossos pais o que eles tinham feito contra o nazismo, eles respondiam: 'Não sabíamos'. Na verdade, o que aconteceu nos campos só fio descoberto depois de 1945, com as fotos de Margaret Bourke-White. Mas nós, quando nossos filhos perguntarem: 'O que vocês fizeram contra o genocídio de Ruanda?', teremos que responder: 'Estávamos ocupados com Stefanie de Mônaco."' (RAMONET, 1999, p. 11)
} 
É precisamente este distanciamento da imprensa em relação às pessoas que, em nossa visão, torna o jornalismo colaborativo -a emersão de um jornalismo feito pelo (antigo) público, ou que convoque as pessoas de maneira mais ostensiva à participaçãoferramenta tão valiosa. E também fenômeno tão próximo à pedagogia proposta por Freire. Porque, assim como a educação tradicional, avaliada pelo autor, a nós parece que a mídia tradicional também fala com as pessoas pela sloganização, pela verticalidade, pelo "depósito de informação" —a mesma cultura bancária que Freire critica na educação. Este processo de mera narração, semelhante ao que o jornalismo tradicional produz, transforma o jornalista em sujeito (emissor) e o público em objeto (receptor), conduzindo o público à memorização mecânica de conteúdos, transformando o leitor ou usuário no que Freire chama de "vasilha" —recipientes a serem enchidos pela notícia, no caso do jornalismo, ou pelo conteúdo programático, no caso da educação. O que prejudica a compreensão do conteúdo:

\footnotetext{
"Nosso papel não é falar ao povo sobre a nossa visão do mundo, ou tentar impô-la a ele, mas dialogar com ele sobre a sua e a nossa. Temos de estar convencidos de que a sua visão do mundo, que se manifesta nas várias formas de sua ação, reflete a sua situação no mundo, em que se constitui. A ação educativa e política não pode prescindir do conhecimento crítico dessa situação, sob pena de se fazer 'bancária' ou de pregar no deserto. Por isto mesmo é que, muitas vezes, educadores e políticos falam e não são entendidos. Sua linguagem não sintoniza com a situação concreta dos homens a quem falam. E sua fala é um discurso a mais, alienado e alienante." (FREIRE, 2005, p. 100)
}

Ao contrário do que convencionou-se como negócio da grande imprensa, que deposita seu discurso a milhões de pessoas todos os dias, o jornalismo colaborativo pode ajudar na libertação do público incitando-o a criar seu próprio discurso, sua própria pronúncia do mundo. Tornando a mídia um ambiente de diálogo, e não de monólogo: 


\begin{abstract}
"Se é dizendo a palavra com que, "pronunciando" o mundo, os homens o transformam, o diálogo se impõe como caminho pelo qual os homens ganham significação enquanto homens. Por isto, o diálogo é uma exigência existencial. $E$, se ele é o encontro em que se solidarizam o refletir e o agir de seus sujeitos endereçados ao mundo a ser transformado e humanizado, não pode reduzir-se a um ato de depositar idéias de um sujeito no outro, nem tampouco tornar-se simples troca de idéias a serem consumidas pelos permutantes. (...) Porque é encontro de homens que pronunciam o mundo, não deve ser doação do pronunciar de uns a outros. É um ato de criação. Daí que não possa ser manhoso instrumento de que lance mão um sujeito para a conquista do outro. A conquista implícita no diálogo é a do mundo pelos sujeitos dialógicos, não a de um pelo outro. Conquista do mundo para a libertação dos homens." (FREIRE, 2005, p. 91)
\end{abstract}

Para Freire, o caminho para a essa transformação é a colaboração: "(...) na teoria dialógica da ação, os sujeitos se encontram para a transformação do mundo em colaboração" (2005, p. 191). No monólogo característico da educação bancária ou da imprensa tradicional, a manipulação anestesia as massas populares e facilita sua dominação. Já no diálogo presente na colaboração, a manipulação cede lugar à organização —que exige, segundo o autor, um processo de liderança. Mas não uma liderança que pretenda substituir a opressão existente, mas que haja em contato "ousado e amoroso", em conjunto com o povo, e não para o povo:

\begin{abstract}
"A organização das massas populares em classe é o processo no qual a liderança revolucionária, tão proibida quanto estas, de dizer sua palavra, instaura o aprendizado da pronúncia do mundo, aprendizado verdadeiro, por isto, dialógico. Daí que não possa a liderança dizer sua palavra sozinha, mas com o povo. A liderança que assim não procesa, que insista em impor sua palavra de ordem, não organiza, manipula o povo. Não liberta, nem se liberta, oprime." (FREIRE, 2005, p. 205)
\end{abstract}

Por isso torna-se necessário, em nosso ponto de vista, estender o estudo sobre o papel do jornalista enquanto liderança -moderador de discursos em um cenário de produção colaborativa de conteúdo. Alguém capaz de fazer emergir a pronúncia do mundo do (antigo) público, engajando-o. 
JORNALISMO E AUTORIA DIGITAL

Ao prosseguir em nosso intuito de concluir o estudo apontando rumos para estudos futuros, deparamo-nos neste ponto com o estudo da autoria -mais especificamente das transformações que ela sofreu com o advento do computador e da Internet. Como o jornalista tem sua realidade transformada por elas, e como elas podem ajudá-lo?

Um breve percurso bibliográfico nos revelou nos estudos de Janet Murray em seu "Hamlet no Holodeck" alternativas para chegar a um novo paradigma para a atuação do jornalista enquanto autor que podem ser melhor exploradas em pesquisas específicas e de maior profundidade.

Hamlet, o personagem shakespeariano, o leitor certamente já conhece. O holodeck, no entanto, é considerado no livro como a "mais poderosa tecnologia de ilusão sensorial que se pode imaginar" (MURRAY, 2003, p. 39). Criação da série de ficção científica "Jornada nas Estrelas", consiste de um cubo negro e vazio, coberto por uma grade de linhas brancas, sobre o qual um computador pode projetar elaboradas simulações, combinando holografia com campos de força magnéticos e conversão de energia em matéria. Dentro do holodeck, o usuário não lê a história, ele participa dela. E diferentemente do distanciamento da tela do computador ou da ilusão óptica de um cinema 3D, ele pode tocar e interagir materialmente com os personagens. Com o título de seu livro, a autora propõe exatamente o movimento de levar as narrativas clássicas para um ambiente de interação que engaje o interator e leve-o à ação —ainda que, cabe aqui a ressalva, ação sobre um mundo ficcional, distante da realidade.

Murray cita em sua obra um episódio de "Jornada nas Estrelas" cujo desafio da capitã Janeway, que vive em seu holodeck um romance com um lorde da época vitoriana, é lidar com uma forma alienígena invisível aos olhos humanos que induz alucinações nos tripulantes da Enterprise, ameaçando a segurança da nave. Mas Janeway consegue reconhecer o farsante, e apaga o programa de computador que gerava sua história com o 
lorde do século 19. Diferentemente de personagens de Aldous Huxley em "Admirável Mundo Novo" ou Ray Bradbury em "Fahrenheit 451", colocados como vítimas das tecnologias, Janeway é a mestra do dispositivo que está criando a ilusão. Ela mantém o controle sobre a história, da mesma forma que, ao ler um livro e mergulhar em seu enredo, um leitor pode a qualquer tempo fechar o volume e emergir das páginas.

Deste cenário então surgem, para nós, alguns paralelos interessantes. O primeiro é o papel ativo da capitã na interação —algo que remete ao jornalismo colaborativo e ao engajamento que Freire propõe ao "oprimido", aqui tido como (antigo) público que desejamos convidar à participação. O segundo, é o tipo de preparação e mentalidade que o jornalista deve começar a ter para criar histórias que não apenas possam ser narradas, mas também vivenciadas em plataformas tecnológicas que, cada vez mais, permitirão participação ativa do (antigo) público. É a chamada autoria procedimental:

\footnotetext{
"Precisaremos descobrir uma maneira que permita a eles [os autores] escrever de forma procedimental; antecipar todas as reviravoltas do caleidoscópio, todas as ações do interator, e especificar não apenas os acontecimentos do enredo, mas também as regras sob as quais estes eventos ocorrerão. Os escritores precisaram de um método concreto para estruturar uma historia coerente, não como uma sequencia isolada de eventos, mas como um enredo multiforme aberto a participação colaborativa do interator." (MURRAY, 2003, p. 179)
}

É um jogo, o RPG (role-playing game, ou jogo de atuação), uma das formas mais ativas para engajamento na construção destes cenários interativos, segundo a autora. Isso porque os jogadores são atores e espectadores uns dos outros, e os eventos que eles encenam frequentemente possuem o imediatismo das experiências pessoais. Nos jogos temos a possibilidade de simular nossa relação mais básica com o mundo: nosso desejo de superar os problemas, lidar com as derrotas, criar e recriar nosso ambiente, fazer a vida se encaixar como peças de um quebra-cabeça. "Da mesma forma que as cerimônias religiosas de passagem pelas quais marcamos o nascimento, a maioridade, o casamento e a morte, os jogos são ações rituais que nos permitem encenar simbolicamente os padrões que dão sentido a nossas vidas". (MURAY, 2003, p. 141) 
No contexto da autoria procedimental, o autor digital passa então a escrever mais do que simples textos —ele cria cenários. O autor constrói mundos interativos que facilitem a imersão do (antigo) público em um novo tipo de narrativa, cria as "leis" que regem este universo e as possibilidades de ação do interator dentro dele.

E por que não lançar mão dos jogos para complementar a narrativa jornalística? Nick Diakopoulos (2009), da Escola de Literatura, Comunicação e Cultura do Instituto de Tecnologia da Georgia (EUA), participa do projeto "News Games", que procura estudar a relação entre as duas áreas. A principal barreira de integração entre jornalismo e jogos, segundo o autor, é a falta de reconhecimento deste último, normalmente associado com frivolidade e falta de produtividade. As notícias, ao contrário, possuem uma aura ao seu redor -reforçada pelo prestígio das organizações de notícias, que as legitimam. 0 problema, segundo Diakopoulos, é que o noticiário normalmente é centrado em eventos, ações e pessoas -e perde a chance de aproveitar o potencial dos jogos. "Aí está onde os jogos podem prover algo a mais: jornalismo orientado a processos. Por exemplo: como funciona o processo de colégios eleitorais? (...) Os jogos se adaptam perfeitamente à explicação de processos", segundo Diakopoulos, em um formato convincente.

Talvez sem perceber esta tendência, a maior parte dos sites da chamada Web 2.0 já tem funcionalidades muito semelhantes às de jogos. Esta pelo menos é a visão de Cindy Weng em seu "The Web - Hidden Games", em que a autora se debruça sobre o agregador de notícias Digg (http://digg.com), o site de vídeos Youtube (www.youtube.com) e a rede social Facebook (www.facebook.com):

\footnotetext{
"[Enxergar estes sites como jogos] nos auxilia a compreender por que eles são bem sucedidos. Há um padrão desenvolvido que praticamente garante este sucesso: cada site tem suas próprias metas, facilidade de jogo, estratégias e recompensas. Como há objetivos aos usuários, eles não se sentem perdendo tempo quando contribuem para o site. Há um certo grau de sucesso conquistado quando você 'vence', e isso é suficiente para que participar de Digg, Youtube e Facebook valha a pena. Outro fator é a facilidade de 'jogar os jogos'. Não é necessário fazer uma cirurgia cerebral para perceber como as coisas funcionam, e o sucesso é mais baseado na personalidade que em habilidades. Qualquer um pode encontrar uma notícia interessante e submetê-la ao Digg; qualquer um pode gravar um vídeo e colocá-lo no Youtube; todos têm amigos e podem construir suas redes no Facebook. (...) Fazer as coisas de um jeito divertido é a nova tendência." (WENG, 2007, p. 120)
} 
O "jeito divertido" pode ser uma das maneiras que o jornalista, enquanto autor digital, pode encontrar para motivar o (antigo) público a se aproximar do noticiário e iniciar a construção de um diálogo. Ao mesmo tempo, para concluir nossos apontamentos para estudos futuros, julgamos que interessará ao pesquisador que quiser se aprofundar no desenvolvimento do jornalismo colaborativo no Brasil compreender características que fundam o espírito brasileiro, de um ponto de vista antropológico e sociológico, justamente para evitar a importação de soluções à nossa realidade, o que afasta e aliena, como alerta Freire. Desta forma abre-se o caminho para a discussão de obstáculos e facilitadores para a motivação do público brasileiro, de forma a engajá-lo na construção do noticiário.

\section{MOTIVAÇÕES DA COLABORAÇÃO E AS RAÍZES DO BRASIL}

O engajamento com a produção da informação sobre a própria realidade, que leva a um aprofundamento de visão sobre si mesmo e sobre a sociedade em que está inserido, deve fundar qualquer iniciativa que deseje proclamar-se jornalismo colaborativo; e não a simples abertura de sistemas de publicação ao grande público (liberdade de publicação) ou a possibilidade de fazer parte do cenário midiático, seja comentando-o, seja corrigindo-o em plataformas da própria mídia de massa, ou em plataformas independentes.

Bowman e Willis (2003) elencam alguns dos que consideram os principais motivos que levam uma pessoa a aderir a uma rede social e, uma vez dentro dela, interagir com outros usuários. O primeiro deles é ganhar status ou construir uma reputação em determinada comunidade. "O reconhecimento social é uma das maiores motivações, intoxicando os participantes com gratificação e aprovação instantâneas." (2003, p. 38) Este reconhecimento também pode se traduzir em remuneração —outra motivação à colaboração, não abordada diretamente pelos autores, já que pequenos empresários, consultores ou escritores podem construir reputação positiva e traduzi-la em 
oportunidades de negócios no mundo real. O próximo fator de motivação citado pelos autores é a criação de conexões com pessoas que tenham interesses similares, tanto no mundo real como no virtual:

\begin{abstract}
"As pessoas querem nutrir suas obsessões e dividi-las com pessoas que pensam como elas. Isso é o que motiva, em grande parte, muitas das conexões sociais na Internet. Seja uma página de fãs do pianista e vocalista de jazz dos anos 50 e 60 Buddy Greco ou um banco de dados de aerofólios usados no projeto de um avião, as pessoas estão usando comunidades online para compartilhar paixões, credos, hobbies e estilos de vida. Stuart Golgoff, do Departamento de Aprendizado Distribuído da Universidade do Arizona, diz que 'enquanto as salas de bate-papo, os newsgroups, os fóruns e os quadros de mensagens exercem um papel na comunicação mediada pelo computador, a Web assumiu um lugar proeminente para forjar relações entre pessoas com interesses comuns'." (BOWMAN; WILLIS, 2003, p. 39).
\end{abstract}

Outra motivação à colaboração destacada pelos autores é a necessidade das pessoas em melhor compreenderem o mundo e darem sentido às informações. Isso porque, para Kovach e Rosenstiel ${ }^{62}$ (2004 apud BOWMAN; WILLIS, 2003, p.41), "o tipo de jornalismo que tem foco na elite especialista é, em parte, responsável pela desilusão do público. Esse tipo de noticiário não reflete o mundo como as pessoas o vivem e experimentam", dizem os autores -o que faz eco e confirma nossa percepção ao paralelizar a imprensa tradicional à pedagogia bancária descrita por Freire (2003).

\begin{abstract}
"Expostas a um enorme fluxo de informações de uma grande quantidade de fontes de mídia, as pessoas têm recorrido mais a comunidades online para aprender e dar sentido às coisas. (...) Veja o crescente número de especialistas no noticiário tentando explicar flutuações de mercado, manobras políticas ou avanços médicos. (...) Weblogs, fóruns, usenets e outras formas de sociabilidade online se tornaram mananciais de sentido em tempo real sobre qualquer assunto. Eles também funcionam como arquivos de perspectivas." (BOWMAN; WILLIS, 2003, p.41)
\end{abstract}

Além da informação, a diversão também é um fator de motivação para a colaboração segundo os autores. E por fim, o processo de criação também é um estímulo: "Aqueles que participam online normalmente criam conteúdo para informar e entreter os outros. Mas criar também constrói a auto-estima e, na visão de Maslow, é um ato de realização

${ }^{62}$ KOVACH, Bill \& ROSENSTIEL, Tom. Os elementos do jornalismo: O que os jornalistas devem saber e o público exigir. São Paulo: Geração Editorial, 2004. 
pessoal" (BOWMAN; WILLIS, 2003, p. 42). A autora norte-americana Amy Jo Kim (2000) também recorre ao psicólogo Abraham Maslow para compreender motivações na rede. Maslow acreditava que as pessoas são motivadas a fazer algo pela compulsão em satisfazer desejos, desde os básicos, ligados à sobrevivência, até os mais complexos ou abstratos, ligados à satisfação pessoal. Ele também acreditava que as necessidades complexas não poderiam ser satisfeitas enquanto as mais básicas não o fossem. Bowman e Willis (2003, p. 39) usam a pirâmide de Maslow para comparar os objetivos e necessidades de participantes de comunidades online:

\section{TABELA 1}

A Hierarquia de Necessidades de Maslow e as Comunidades Online

Necessidade

\begin{tabular}{ccc} 
Necessidade & Offline (Maslow) \\
\hline Fisiologia & Comida, roupa, abrigo, saúde \\
\hline Segurança & $\begin{array}{c}\text { Proteção de crimes e guerras, o } \\
\text { senso de viver em uma sociedade } \\
\text { justa }\end{array}$
\end{tabular}

\begin{tabular}{|c|c|c|}
\hline Amor/Relacionamento & $\begin{array}{l}\text { Habilidade de dar e receber amor, } \\
\text { sentimento de pertencer a um grupo }\end{array}$ & $\begin{array}{l}\text { Pertencer à comunidade como um } \\
\text { todo, e a subgrupos dentro da } \\
\text { comunidade }\end{array}$ \\
\hline Estima & $\begin{array}{l}\text { Respeito próprio, habilidade de } \\
\text { ganhar o respeito dos outros e } \\
\text { contribuir para a sociedade }\end{array}$ & $\begin{array}{c}\text { Capacidade de contribuir à } \\
\text { comunidade e ser reconhecido por } \\
\text { estas contribuições }\end{array}$ \\
\hline Realização Pessoal & $\begin{array}{l}\text { Capacidade de auto- } \\
\text { desenvolvimento e conquista de seu } \\
\text { potencial }\end{array}$ & $\begin{array}{c}\text { Capacidade de assumir } \\
\text { responsabilidade um papel dentro da } \\
\text { comunidade capaz de desenvolver } \\
\text { habilidades e criar novas } \\
\text { oportunidades }\end{array}$ \\
\hline
\end{tabular}

Acesso ao sistema, habilidade de obter e manter uma identidade enquanto participa de uma comunidade virtual

Proteção contra hackers e ataques pessoais, capacidade de manter diversos níveis de privacidade

Pertencer à comunidade como um subgrupos dentro da

( 
"(...) sei de pelo menos três razões que me levaram a reescrever aquela descrição. A primeira foi a chance de exercitar algumas capacidades mentais adormecidas - estudei fractais em uma disciplina de física na faculdade na década de 1980 e fiquei feliz em lembrar o suficiente sobre a bola de neve de Koch para ser capaz de dizer algo útil sobre ela, apesar de modesto. A segunda razão foi vaidade -o prazer de mudar alguma coisa no mundo, só para ver meu nome nela. (...) A terceira fio o desejo de fazer algo de bom."

Observa-se portanto que as motivações para a colaboração online ainda merecem estudo mais aprofundado e sistemático -e, no caso brasileiro, mereceriam em nosso ponto de vista uma associação mais profunda a análises antropológicas e sociológicas do Brasil e do brasileiro em si, além de características específicas de sua relação com a Internet, para evitar a mera "importação" de soluções, como já explicitamos.

Um dos caminhos para mapear os desafios do cenário brasileiro à adoção do jornalismo colaborativo seria, a nosso ver, aprofundar estudos de características socioculturais que diferenciam o povo brasileiro das populações de onde importamos as principais soluções tecnológicas de nosso tempo. À ética protestante e o espírito do capitalismo, opõem-se as raízes do Brasil -e nosso jogo de palavras aqui tem intenção. Em seu "Raízes do Brasil", Sérgio Buarque de Holanda traça um perfil social do brasileiro a partir de nossa origem ibérica, que, segundo o autor, predomina sobre todas as outras em nosso arcabouço cultural. $E$ isso teve consequências que nos diferenciam dos norteamericanos que usam o Digg ou dos sul-coreanos que fazem do OhMyNews o principal site de jornalismo colaborativo do mundo. A primeira delas é que ao tentar implantar a cultura ibérica em um território extenso, de condições naturais diversas das encontradas na Europa, e trazendo de lá nossas formas de convívio, instituições e ideias, acabamos por nos tornar "desterrados em nossa própria terra" (HOLANDA, 2004, p. 31). É como se a alienação detectada por Freire (2005) ganhasse ainda mais peso -e tivesse seu fecho por fim cerrado com a dinâmica de dominação social detectada por Castells (2006):

"A forma fundamental de dominação de nossa sociedade baseia-se na capacidade organizacional da elite dominante que segue de mãos dadas com sua capacidade de desorganizar os grupos da sociedade que, embora constituam maioria numérica, vêem (se é que vêem) seus interesses parcialmente representados apenas dentro da estrutura do atendimento dos interesses dominantes. 
A articulação das elites e a segmentação e desorganização da massa parecem ser os mecanismos gêmeos de dominação social em nossas sociedades. (...) as elites são cosmopolitas, as pessoas são locais. (...) Portanto, quanto mais uma organização social baseia-se em fluxos aistóricos, substituindo a lógica de qualquer lugar específico, mais a lógica do poder global escapa ao controle sociopolítico das sociedades locais/nacionais historicamente específicas." (CASTELLS, 2006, p. 504)

A esta sensação soma-se um certo culto à personalidade, ao individualismo, que fez com que, segundo Holanda, os brasileiros herdássemos de nossos ancestrais portugueses e espanhóis certa dificuldade em fazerem surgir organizações sociais espontâneas e duradouras entre nós:

\begin{abstract}
"Precisamente a comparação entre elas [as culturas ibéricas] e as da Europa de além-Pirineus faz ressaltar uma característica bem peculiar à gente da península Ibérica, uma característica que ela está longe de partilhar, pelo menos na mesma intensidade, com qualquer de seus vizinhos do continente. É que nenhum desses vizinhos soube desenvolver a tal extremo essa cultura da personalidade, que parece constituir o traço mais decisivo na evolução da gente hispânica, desde tempos imemoriais. (...) Para eles, o índice do valor de um homem infere-se, antes de tudo, da extensão em que não precise depender dos demais, em que não necessite de ninguém, em que se baste. (...) É dela que resulta largamente a singular tibieza das formas de organização, de todas as associações que impliquem solidariedade e ordenação entre esses povos. Em terra onde todos são barões não é possível acordo coletivo durável, a não ser por uma força exterior respeitável e temida." (HOLANDA, 2004, p. 32)
\end{abstract}

Outro desafio a ser vencido também diz respeito ao contraste entre a cultura herdada dos povos ibéricos e a cultura protestante —seria nossa falta de apreço ao trabalho ou sua ligação ao mérito, à salvação. Segundo o autor, a atitude normal do povo ibérico -e que, portanto, influencia até hoje nossa cultura- é precisamente a inversa, em que "o 'ser', a 'gravidade', o 'termo honrado', o 'proceder sisudo', esses atributos que ornam e engrandecem (...) representam virtudes essencialmente inativas, pelas quais o indivíduo se reflete sobre si mesmo e renuncia a modificar a face do mundo":

"É compreensível, assim, que jamais se tenha naturalizado entre gente hispânica a moderna religião do trabalho e o apreço à atividade utilitária. Uma digna ociosidade sempre pareceu mais excelente, até mais nobilitante, a um bom português, ou a um espanhol, do que a luta insana pelo pão de cada dia. O que ambos admiram como ideal é uma vida de grande senhor, exclusiva de qualquer esforço, de qualquer preocupação. E assim, enquanto povos protestantes preconizam e exaltam o esforço manual, as nações ibéricas colocam-se ainda largamente no ponto de vista da Antiguidade clássica. O que entre elas predomina é a concepção antiga de que o ócio importa mais que o negócio e de que a atividade produtora é, em si, menos valiosa que a contemplação e o amor." (HOLANDA, 2004, p. 38) 
Coloca-se no destrinchar destas questões culturais, ao lado do desenvolvimento de estudos sobre o papel educativo do jornalismo colaborativo sob a óptica de Paulo Freire e de ferramentas que possam auxiliar o jornalista em seu novo papel de autor digital, o maior desafio das iniciativas que pretendam levar o jornalismo colaborativo a todo seu potencial no Brasil. Para que a visão dos primeiros autores que se debruçaram sobre ele possa florescer como a ampliação da democracia, do acesso à informação e da realização do jornalismo como ferramenta de transformação e justiça social.

Contudo, apesar das evidências de nosso estudo, e diante dos aspectos delimitadores que já apontamos na estruturação de nossa metodologia, é fundamental retomarmos o caráter não conclusivo e não generalizador da pesquisa, deixando espaço para a discussão do conceito de jornalismo colaborativo e sua adequação às características das operações de mídia informativa na web brasileira.

Há que se ressaltar também que existe na web brasileira uma sucessão de iniciativas independentes - a exemplo do Centro de Mídia Independente, braço do site Indymedia no Brasil, do Wikinews de e outros casos nacionais, como o próprio Overmundo ou o BrasilWiki, já citados em capítulos anteriores- destinadas exclusivamente ao engajamento do cidadão como participante da cena social que, por suas características e recortes editoriais, favorecem uma exposição de jornalismo bem mais próxima da colaboração que aquela provida pelos portais. Neste estágio da pesquisa, no entanto, não nos ateremos ao estudo dessas iniciativas, especialmente pela falta de abrangência de seu público, como definido previamente em nosso recorte. Porém neste âmbito também é possível enxergar uma série de estudos possíveis para buscar melhor compreender a natureza e a prática do jornalismo colaborativo no Brasil. 


\section{REFERÊNCIAS}

ANDERSON, Chris. A Cauda Longa: do mercado de massa para o mercado de nicho. Rio de Janeiro: Elsevier, 2006.

BENTLEY, Clyde H. Reconecting with the audience. Nieman Reports, Cambridge: Nieman Foundation for Journalism at Harvard, 2005. Disponível em: $<$ http://www.nieman.harvard.edu/reportsitem.aspx?id=100566>. Acesso em: 17 abr. 2009.

BENKLER, Yoshai. The wealth of networks. How social production transforms markets and freedom. New Haven: Yale University Press, 2006.

BOLTER, Jay David; MACINTYRE, Blair; GANDY, Maribeth; SCHEWEITZER, Petra. New Media and the Permanent Crisis of Aura. Convergence: The International Journal of Research into New Media Technologies, Thousand Oaks, v. 12, n. 1 p. 21-39, 2006. Disponível em: <http://con.sagepub.com/cgi/content/abstract/12/1/21>. Acesso em: 22 abr. 2009.

BORGES, Susana. A segunda fase do Jornalismo Público. Estudos em Comunicação, Covilhã, n. 5, p. 95-113, 2009. Disponível em: <http://www.labcom.ubi.pt/ec/05/>. Acesso em 21 jun. 2009.

BOSI, Ecléa. O Tempo Vivo da Memória, Ensaios de Psicologia Social. São Paulo: Ateliê Editorial, 2003.

BOWMAN, Shayne e WILLIS, Chris. We Media: How audiences are shaping the future of news and information. Reston: Media Center at American Press Institute, 2003. Disponível em: <http://www.hypergene.net/wemedia/download/we media.pdf>. Acesso em: 12 mar. 2009.

. The Future Is Here, But Do News Media Companies See It? Nieman Reports, Cambridge: Nieman Foundation for Journalism at Harvard, 2005. Disponível em: <http://www.nieman.harvard.edu/reportsitem.aspx?

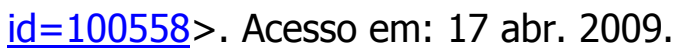

BRAMBILLA, Ana Maria. Jornalismo open source: discussão e experimentação do OhMyNews International. 2006. 251 f. Dissertação (Mestrado em Comunicação e Informação) - Faculdade de Biblioteconomia e Comunicação, Universidade Federal do Rio Grande do Sul, Porto Alegre, 2006. Disponível em: <http://www.lume.ufrgs.br/ bitstream/handle/10183/8457/000576267.pdf>. Acesso em: 15 ago. 2007.

BRIGGS, Asa; BURKE, Peter. Uma história social da mídia: De Gutenberg à Internet. Rio de Janeiro: Jorge Zahar Editor, 2006. 
BRUNS, Axel. Gatewatching: Collaborative Online News Production. New York: Peter Lang Publishing Inc., 2005.

Wikinews: The Next Generation of Alternative Online News? Scan Journal, Sydney, v. 3, n. 1, 2006. Disponível em: <http://eprints.qut.edu.au/4862/>. Acesso em 5 ago. 2009.

CALLEJA, Gordon. Digital Game Involvement: A Conceptual Model. Games and Culture, Los Angeles, v. 2, n. 3, p. 236-260, 2007. Disponível em: < http://gac.sagepub. com/cgi/content/abstract/2/3/236>. Acesso em: 18 abr. 2009.

CAMMAERTS, Bart; CARPENTIER, Nico (org.). Reclaiming the media: Communication Rights and Democratic Media Roles. Bristol: Intellect Books, 2007.

CASTELLS, Manuel. A Sociedade em Rede: A era da informação: Economia, Sociedade e Cultura; v. 1. São Paulo: Paz e Terra, 1999.

CHAPARRO, Manuel Carlos. Pragmática do jornalismo: Buscas práticas para uma teoria da ação jornalística. 2. ed. São Paulo: Summus, 1994.

CHARITY, Artur. Doing Public Journalism. New York: The Guilford Press, 1995.

CHUNG, Deborah Soun. Profits and Perils: Online News Producers' Perceptions of Interactivity and Uses of Interactive Features. Convergence: The International Journal of Research into New Media Technologies, London, Vol 13, n. 1, p. 43-61, 2007. Disponível em <http://con.sagepub.com/cgi/content/abstract/13/1/43>. Acesso em: 17 abr.2009.

COLEMAN, Renita; LIEBER, Paul; MENDELSON, Andrew L.; KURPIUS, David d. Public life and the Internet: if you build a better website, will citizens become engaged? New Media \& Society, Los Angeles, v. 10, n. 2, p. 179-201, 2008. Disponível em: $<$ http://nms.sagepub.com/cgi/content/abstract/10/2/179>. Acesso em: 17 abr.2009.

DANTAS, Audálio (org.). Repórteres. São Paulo: Editora Senac, 1998.

DAVID, Yu Siqi. The Role of Editors in Participatory Journalism. Beijing: Peking University, 2007. Disponível em: <http://bybk.pku.edu.cn/UploadFiles/20076/626466514.doc>. Acesso em: 17 abr. 2009.

DEUZE, Mark. Ethnic media, community media and participatory culture. Journalism, Thousand Oaks, v. 7, n. 3, p. 262-280, 2006. Disponível em: < http://jou.sagepub.com/cgi/content/abstract/7/3/262 >. Acessado em: 17 abr. 2009.

. The Media Logic of Media Work. Journal of Media Sociology, Washington, v.1, n.1/2, p. 22-40, 2009. Disponível em: <http://www.marquettejournals. org/accessthejournals/jourofmediasociology.html>. Acesso em: 11 jun. 2009.

Towards Professional Participatory Storytelling: Mapping the Potential. In: MIT4 conference, Cambridge, 2005. Anais eletrônicos, Cambridge: MIT, 2005. 
Disponível em: <http://web.mit.edu/comm-forum/mit4/papers/Deuze.pdf>. Acesso em: 11 jan. 2009.

DIAKOPOULOS, Nick. Functional and Cultural Tensions and Opportunities for Games in Journalism. News Games, Atlanta, 2009. Disponível em: <http:// jag.lcc.gatech.edu/blog/2009/02/functional-and-cultural-tensions-and-opportunities-forgames-in-journalism.html>. Acesso em 17 abr. 2009.

ESCOSTEGUY, Ana Carolina D. Os estudos culturais em debate. UNIrevista, v. 1, n. 3, 2006. Disponível em: <http://www.unirevista.unisinos.br/\#TMPC>. Acesso em: 17 abr. 2009.

FERBER, Paul; FOLTZ, Franz; PUGLIESE, Rudy. Community Networks and Public Participation: A Forum for Civic Engagement or a Platform for Ranting Irate Malcontents? Bulletin of Science, Technology \& Society, v. 26, n. 5, p. 388-397, 2006. Disponível em: <http://bst.sagepub.com/cgi/content/abstract/26/5/388>. Acesso em: 17 abr. 2009.

FERNBACK, Jan. Beyound the diluted comunity concept: a symbolic interactionist perspective on online social relations. New Media \& Society, Thousand Oaks, v. 9, n. 1, p. 49-69, 2007. Disponível em: <http://nms.sagepub.com/cgi/content/abstract/9/1/49>. Acessado em: 22 abr. 2009.

FERRARI, Simon. History of Editorial Games, Part One. News Games, Atlanta, 2009. Disponível em: <http://jag.lcc.gatech.edu/blog/2009/06/history-of-editorial-games-partone.html>. Acesso em: 4 ago. 2009.

FOLHA DE S. PAULO. Novo Manual da Redação. 8. ed. São Paulo: Folha de S. Paulo, 1992.

FREIRE, Paulo. Educação como Prática da Liberdade. $41^{\mathrm{a}}$ ed. Rio de Janeiro: Paz e Terra, 2009.

37a ed. São Paulo: Paz e Terra, 1996.

Pedagogia do oprimido. 47a ed. Rio de Janeiro: Paz e Terra, 2005.

GALLOWAY, Alexander R. Protocol: how control exists after descentralization. Cambridge: Massachussets Institute of Technology, 2004.

GARRIS, Rosemary; AHLERS, Robert; DRISKELL, James E. Games, Motivation, and Learning: A Research and Practice Model. Simulation \& Gaming, Detroit, v. 33, n. 4, p. 441-467, 2002. Disponível em: <http://sag.sagepub.com/cgi/content/abstract/33/4/441>. Acesso em: 18 abr. 2009.

GLASER, Mark. Your Guide to Hyper-local News. Disponível em: <http:// www.pbs.org/mediashift/2007/12/your-guide-to-hyper-local-news347.html>. Acesso em 10 mar. 2009. 
GLASSER, Theodore Lewis (org). The idea of public journalism. New York: Guilford Press, 1999.

GILLMOR, Dan. We The Media: Grassroots journalism by the people, for the people. Sebastopol: O'Reilly Media, 2004.

. Where Citizens and Journalists Intersect. Nieman Reports, Cambridge: Nieman Foundation for Journalism at Harvard, 2005. Disponível em: $<$ http://www.nieman.harvard.edu/reportsitem.aspx?id=100559 >. Acesso em: 17 abr. 2009.

GLOCK, Hans-Johann. Dicionário Wittgenstein. Tradução de Helena Martins. Rio de Janeiro: Jorge Zahar Editor, 1997.

GORDON, Eric; KOO, Gene. Placeworlds: Using Virtual Worlds to Foster Civic Engagement. Space and Culture, Nottingham, v. 11, n. 3, p. 204-221, 2008. Disponível em: <http://sac.sagepub.com/cgi/content/abstract/11/3/204>. Acesso em: 17 abr. 2009.

GORDON, Janey. The Mobile Phone and the Public Sphere: Mobile Phone Usage in Three Critical Situations. Convergence: The International Journal of Research into New Media Technologies, London, v. 13, n. 3, p. 307-319, 2007. Disponível em <http://con.sagepub.com/cgi/content/abstract/13/3/307>. Acesso em: 17 abr.2009.

GULLI, Antonio; SIGNORINI, Alessio. The Indexable Web is more than $\mathbf{1 1 , 5}$ billion pages. Chiba: University of Iowa, 2005. Disponível em: $<$ http://www.cs.uiowa.edu/ asignori/web-size/size-indexable-web.pdf $>$. Acesso em: 15 fev. 2009.

HAAS, Tanni. Importing Journalistic Ideals and Practices? The Case of Public Journalism in Denmark. The Harvard International Journal of Press/Politics, Cambridge, v. 8, n. 2, p. 90-103, 2003. Disponível em: <http://hij.sagepub.com/cgi/ content/abstract/8/2/90>. Acesso em: 17 abr. 2009.

HAAS, Tani; STEINER, Linda. Public journalism: a reply to critics. Journalism, Thousand Oaks, v. 7, n. 2, p. 238-254, 2006. Disponível em: < http://jou.sagepub.com/ cgi/content/abstract/7/2/238>. Acesso em: 17 abr. 2009.

Public journalism as a journalism of publics: Implications of the Habermas-Fraser debate for public journalism. Journalism, Thousand Oaks, v. 2, n. 2, p. 123-147, 2001. Disponível em: <http://jou.sagepub.com/cgi/content/ abstract/2/2/123 >. Acesso em: 17 abr. 2009.

HARRISON, Teresa M.; BARTHEL, Brea. Wielding new media in Web 2.0: exploring the history of engagement with the collaborative construction of media products. New Media \& Society, Los Angeles, v. 11(1\&2), p. 155-178, 2009. Disponível em: <http://nms.sagepub.com/cgi/content/abstract/11/1-2/155>. Acesso em: 17 abr. 2009. 
HATCHER, John. The Routine at The Daily Routine: Exploring the Influence of the Individual in an Age of Media Transformation. Journal of Media Sociology, Washington, v.1, n.1/2, p. 41-59, 2009. Disponível em: <http://www.marquettejournals. org/accessthejournals/jourofmediasociology.html

HOLANDA, Sérgio B. de. Raízes do Brasil. São Paulo: Companhia das Letras, 1995.

HUANG, Edgar. The Causes of Youths' Low News Consumption and Strategies for Making Youths Happy News Consumers. Convergence: The International Journal of Research into New Media Technologies, Los Angeles, v. 15, n. 1, p. 105-122, 2009. Disponível em: <http://con.sagepub.com/cgi/content/abstract/15/1/105>. Acesso em: 17 abr. 2009.

HUJANEN, Jaana; PIETIKÄINEN, Sari. Interactive uses of journalism: crossing between technological potential and young people's news-using practices. New Media \& Society, London, v. 6, n. 3, p. 383-401, 2004. Disponível em: <http://nms.sagepub.com/cgi/ content/abstract/6/3/383 >. Acesso em: 17 abr. 2009.

IBOPE. Número de usuários de banda larga em residências cresceu $\mathbf{2 4 \%}$. São Paulo: Ibope, 2009. Disponível em: <http://www.ibope.com.br/calandraWeb/servlet/ CalandraRedirect?temp $=5 \&$ proj $=$ PortalIBOPE\&pub $=T \& d b=$ caldb\&comp $=$ Noticias \&docid $=$ 1478D4331D733E8C83257584004C7F8 >. Acesso em: 31 mar. 2009.

INSTITUTO BRASILEIRO DE GEOGRAFIA E ESTATÍSTICA. Pesquisa Nacional por Amostra de Domicílios: Síntese de Indicadores 2007. Rio de Janeiro: IBGE, 2007. Disponível em: <http://www.ibge.gov.br/home/estatistica/populacao/trabalhoerendimento/ pnad2007/sintesepnad2007.pdf> . Acesso em: 31 mar. 2009.

INTERNET WORLD STATS. Disponível em: <http://www.Internetworldstats.com>. Acesso em: 31 mar. 2009.

JAGMOHAN, Mala. Book Review: What are journalists for? Journalism, Thousand Oaks, v. 1, n. 2, p. 239-245, 2000. Disponível em: <http://jou.sagepub.com/cgi/reprint/ 1/2/239>. Acesso em: 17 abr. 2009.

JENKINS, Henry. Convergence Culture: Where Old and New Media Collide.New York: New York University Press, 2006.

JENSEN, Klaus Bruhn. Teoria e filosofia da comunicação. Matrizes, São Paulo, ano 2, n. 1, 2008, p. 31-47. Disponível em: <http://www.matrizes.usp.br/ojs/index.php/ matrizes/article/viewPDFInterstitial/48/pdf 42>. Acesso em: 29 abr. 2010.

JOSS, Simon. Toward the Public Sphere $\square$ Reflections on the Development of Participatory Technology Assessment. Bulletin of Science, Technology \& Society, v. 22, n. 3, p. 220-231, 2002. Disponível em: <http://bst.sagepub.com/cgi/content/abstract/ 22/3/220>. Acesso em: 17 abr. 2009. 
JÚNIOR, Caio Prado. Formação do Brasil Contemporâneo. São Paulo: Brasiliense; Publifolha, 2000.

KAFAI, Yasmin B. Playing and Making Games for Learning: Instructionist and Constructionist Perspectives for Game Studies. Games and Culture, Los Angeles, v. 1, n. 1, p. 36-40, 2006. Disponível em: <http://gac.sagepub.com/cqi/content/abstract/1/1/36>. Acesso em 18 abr. 2009

KEEN, Andrew. The cult of the amateur: how today's Internet is killing our culture. New York: Doubleday; Currency, 2007.

KELLEMEN, Peter. Brasil para principiantes: venturas e desventuras de um brasileiro naturalizado. Rio de Janeiro: Civilização Brasileira, 1963.

KIM, Amy Jo. Community Building on the Web: Secret Strategies for Successful Online Communities. Berkeley: Peachpit Press, 2000.

KOVACH, Bill \& ROSENSTIEL, Tom. Os elementos do jornalismo: O que os jornalistas devem saber e o público exigir. São Paulo: Geração Editorial, 2004.

LAGE, Nilson. A reportagem: Teoria e técnica de entrevista e pesquisa jornalística. Rio de Janeiro: Record, 2001.

LENHART, Amanda; FOX, Susannah. Bloggers: A portrait of the Internet's new storytellers. Washington: Pew Internet \& American Life Project, 2006. Disponível em: $<$ http://www.pewInternet.org/ /media//Files/Reports/2006/PIP\%20Bloggers\%20Report \%20July\%2019\%202006.pdf.pdf>. Acesso em: 28 fev. 2009.

LESSIG, Lawrence.Free Culture: How big media uses technology and the Law to lock down culture and control creativity. New York: The Penguin Press, 2004.

LEWIS, Justin. News and the empowerment of citizens. European Journal of Cultural Studies, London, v. 9, n. 3, p. 303-319, 2006. Disponível em: <http://ecs.sagepub.com/cgi/content/abstract/9/3/303>. Acesso em: 17 abr. 2009.

LIH, Andrew. The Foundations of Participatory Journalism and the Wikipedia Project. In: Association for Education in Journalism and Mass Communications, Communication Technology and Policy Division Conference, 2004, Toronto. Anais eletrônicos. Hong Kong: Hong Kong University, 2004. Disponível em <http://jmsc.hku.hk/faculty/alih/ publications/aejmc-2004-final-forpub-3.pdf>. Acesso em: 17 abr. 2009.

LOWREY, Wilson. Mapping the journalism-blogging relationship. Journalism, Thousand Oaks, v. 7, n. 4, p. 477-500, 2006. Disponível em: <http://jou.sagepub.com/cgi/content/abstract/7/4/477>. Acesso em: 17 abr. 2009.

LOWREY, Wilson; ANDERSON, William. The Journalist Behind the Curtain: Participatory Functions on the Internet and their Impact on Perceptions of the Work of Journalism. Journal of Computer-Mediated Communication, Bloomington, v. 10, $\mathrm{n}$. 
3, 2005. Disponível em: <http://jemc.indiana.edu/vol10/issue3/lowrey.html>. Acesso em: 17 abr. 2009.

MÄKINEN, Maarit; KUIRA, Mary Wangu. Social Media and Postelection Crisis in Kenya. The International Journal of Press/Politics, Cambridge, v. 13, n. 3, p. 328-335, 2008. Disponível em <http://hij.sagepub.com/cgi/content/abstract/13/3/328 >. Acesso em: 17 abr. 2009.

MALABY, Thomas M. Beyond Play: A New Approach to Games. Games and Culture, Los Angeles, v. 2, n. 2, p. 95-113, 2007. Disponível em: <http://gac.sagepub.com/ cgi/content/abstract/2/2/95>. Acesso em 18 abr. 2009

MARTINS, Gilberto de Andrade. Metodologias convencionais e não-convencionais e a pesquisa em administração. Caderno de Pesquisas em Administração, São Paulo, v. 0, n. 0, 1994. Disponível em < http://www.regeusp.com.br/arquivos/C00-art01.pdf>. Acesso em: 29 abr. 2010.

MCQUAIL, Denis. Mass Communication Theory. Southampton: Sage Publications, 2005.

MEADOWS, Michael; FORDE, Susan; EWART, Jacqui; FOXWELL, Kerrie. Making good sense: Transformative processes in community journalism. Journalism, Los Angeles, v. 10, n. 2, p. 155-170,2009. Disponível em: <http://jou.sagepub.com/cgi/content/abstract/ 10/2/155>. Acesso em: 17 abr. 2009.

MELO, José Marques de. História social da imprensa: fatores socioculturais que retardaram a implantação da imprensa no Brasil. Porto Alegre: EDIPUCRS, 2003.

MERRITT, Davis. Public Journalism and Public Life: Why Telling the News Is Not Enough. New Jersey: Lawrence Erlbaum Associates, 1998.

MIÈGE, Bernard. La société conquise par la communication. Grenoble: Presses universitaires de Grenoble, 1989.

MIN, Jean K. Journalism as a Conversation. Nieman Reports, Cambridge: Nieman Foundation for Journalism at Harvard, 2005. Disponível em: <http://www.nieman.harvard.edu/reportsitem.aspx?id=100562>. Acesso em: 17 abr. 2009.

MOREIRA, Sônia Virgínia. O mundo pelas agências de notícias. Comunicação e Educação, São Paulo, v. 5, p.23-26, 1996. Disponível em: $<$ http://www.revistas.univerciencia.org/index.php/comeduc/article/view/4283>. Acesso em: 11 jun. 2009.

MOHERDAUI, Luciana. Guia de Estilo Web: produção e edição de notícias online. São Paulo: Editora Senac, 2002.

MURRAY, Janet H. Hamlet no Holodeck: o futuro da narrativa no ciberespaço. São Paulo: Itaú Cultural: Unesp, 2003. 
NGUYEN, Na. Journalism in the wake of participatory publishing. Australian Journalism Review, Thirroul, v. 28, n. 1, p. 143-155, 2006. Disponível em: <http://espace.library.uq.edu.au/view/UQ:8062>. Acesso em 17 abr. 2009.

NIELSEN//NETRATINGS ONLINE. Disponível em: <http://www.nielsen-online.com>. Acesso em: 27 mar. 2009.

ORTIZ, Renato. Estudos Culturais. Tempo Social, v.16, n.1, p. 119-127, 2004. Disponível em $\quad<$ http://www.scielo.br/scielo.php?script=sci arttext\&pid=S010320702004000100007\&lng=en\&nrm=iso> . Acesso em 17 abr. 2009.

PARR, Berry. Things I Wish I'd Known Before I Became a Citizen Journalist. Nieman Reports, Cambridge: Nieman Foundation for Journalism at Harvard, 2005. Disponível em: $<$ http://www.nieman.harvard.edu/reportsitem.aspx?id=100568>. Acesso em: 17 abr. 2009.

PEER-TO-PEER. Wikipedia. Disponível em: <http://en.wikipedia.org/wiki/Peer-topeer>. Acesso em 28 mar. 2009.

PENA, Felipe. Teoria do Jornalismo. São Paulo: Editora Contexto, 2005.

PERUZZO, Cicília; BRITTES, Juçara (org.). Sociedade da Informação e Novas Mídias: participação ou exclusão? São Paulo: Intercom, 2002.

QUADROS, Claudia Irene de. A participação do público no webjornalismo. Revista da Associação Nacional dos Programas de Pós-Graduação em Comunicação, Florianópolis, 2005. Disponível em: <http://www.compos.org.br/seer/index.php/ecompos/article/viewFile/56/56>. Acesso em: 12 mar. 2009.

RAMONET, Ignacio. A Tirania da Comunicação. Petrópolis: Vozes, 1999.

REESE, Stephen D.; RUTIGLIANO, Lou; HYUN, Kideuk; JEONG, Jaekwan. Mapping the blogosphere: Professional and citizen-based media in the global news arena. Journalism, Los Angeles, v. 8, n. 3, p. 235-261, 2007. Disponível em: <http://jou.sagepub.com/cgi/ content/abstract/8/3/235>. Acesso em: 17 abr. 2009.

REUTERS. EUA: circulação de jornais cai 3,6\% com concorrência da web. Terra, Porto Alegre, 28 abr. 2008. Disponível em <http://tecnologia.terra.com.br/interna/ $\underline{0}$, OI2844061-EI4802,00-EUA+circulacao+de+jornais+cai+com+concorrencia+da+ web.html>. Acesso em: 15 fev. 2009.

REZENDE, Guilherme Jorge. Telejornalismo no Brasil: um perfil editorial. São Paulo: Summus, 2000.

ROSELLE, Laura. Local Coverage of the 2000 Election in North Carolina: Does Civic Journalism Make a Difference? American Behavioral Scientist, Sedona, v. 46, n. 5, p. 600-616, 2003. Disponível em: <http://abs.sagepub.com/cgi/content/abstract/46/5/600>. Acesso em: 24 abr. 2009. 
SAAD, Beth. Estratégias para a mídia digital: Internet, informação e comunicação. São Paulo: Editora Senac, 2003.

SAFRAN, Steve. How Participatory Journalism Works. Nieman Reports, Cambridge: Nieman Foundation for Journalism at Harvard, 2005. Disponível em: $<$ http://www.nieman.harvard.edu/reportsitem.aspx?id=100564>. Acesso em: 17 abr. 2009.

SAMBROOK, Richard. Citizen Journalism ant the BBC. Nieman Reports, Cambridge: Nieman Foundation for Journalism at Harvard, 2005. Disponível em: $<$ http://www.nieman.harvard.edu/reportsitem.aspx?id=100542>. Acesso em: 17 abr. 2009.

SCOTT, Ben. A Contemporary History of Digital Journalism. Television \& New Media, Riverside, v. 6, n. 1, p. 89-126, 2005. Disponível em: <http://tvn.sagepub.com/ cgi/content/abstract/6/1/89>. Acesso em: 24 abr. 2009

SHAW, Donna. Really Local. American Journalism Review, 2007. Disponível em: <http://www.ajr.org/Article.asp?id=4308>. Acesso em: 10 mar. 2009.

SHIRKY, Clay. Here comes everybody: The Power of Organizing Without Organizations. New York: The Penguin Press, 2008.

SIMON, Imre; VIEIRA, Miguel Said. "O rossio não-rival" in PRETO, Nelson De Luca; SILVEIRA, Sérgio Amadeu da. Além das redes de colaboração: Internet, diversidade cultural e tecnologias do poder. Salvador: EDUFBA, 2008.

SPYER, Juliano. Conectado: O que a Internet fez com você e você pode fazer com ela. São Paulo: Jorge Zahar Editor, 2007.

SUROWIECKI, James. The Wisdom of the Crowds. New York: Anchor Books, 2004.

TAPSCOTT, Don; WILLIAMS, Anthony D. Wikinomics: How Mass Collaboration Changes Everything. New York: The Penguin Group, 2006.

THURMAN, Neil. Forums for citizen journalists? Adoption of user generated content initiatives by online news media. New Media \& Society, London, v. 10, n. 1, p. 139-157, 2008. Disponível em: <http://nms.sagepub.com/cgi/content/abstract/10/1/139>. Aceso em: 17 abr. 2009.

TRAQUINA, Nelson. Teorias do Jornalismo, Por que as notícias são como são, Vol. 1, $2^{a}$ ed. Florianópolis: Insular, 2005.

WENG, Cindy. The Web: Hidden Games. College Park: University of Maryland, 2007. Disponível em: <http://images.lulu.com/content/1269306>. Acesso em: 9 dez. 2007.

WILSON, Katherine A.; BEDWELL, Wendy L.; LAZZARA, Elizabeth H.; SALAS, Eduardo; BURKE, C. Shawn; ESTOCK, Jamie L.; ORVIS, Kara L.; CONKEY, Curtis. Relationships Between Game Attributes and Learning Outcomes: Review and Research Proposals. 
Simulation \& Gaming, Detroit, v. 40, n. 2, p. 217-266, 2009. Disponível em: <http://sag.sagepub.com/cgi/content/abstract/40/2/217>. Acesso em: 18 abr. 2009.

WOLTON, Dominique. É preciso salvar a comunicação. São Paulo: Paulus, 2006.

Internet, e depois? Uma teoria crítica das novas mídias.

Porto Alegre: Sulina, 2003.

WOO, William. Defining a Journalist's Function. Nieman Reports, Cambridge: Nieman Foundation for Journalism at Harvard, 2005. Disponível em: $<$ http://www.nieman.harvard.edu/reportsitem.aspx?id=100569>. Acesso em: 17 abr. 2009. 


\section{ANEXO I :: ENTREVISTAS}

ERIN MIZUTA Jornalista, editora do VC Repórter (Terra)

A jornalista Erin Mizuta concedeu duas entrevistas à pesquisa, uma presencial, outra por e-mail. Nas conversas, revelou que o Terra, em 2009, possuía três jornalistas dedicados ao VC Repórter — dois redatores e uma editora, que se reportava diretamente à diretoria de conteúdo (e não à gerência de jornalismo, como as outras editorias do portal). Para ela, o jornalismo colaborativo encontra-se em uma fase intermediária na Internet brasileira em relação ao desenvolvido em outros países, e avançar exigirá uma mudança cultural mais ampla, que envolve uma maior conscientização social, política e até jurídica, até para que o colaborador saiba o que pode lhe acontecer se publicar uma informação falsa. "Para quê você quer uma nação inteira de jornalistas? Isso é utópico. É o fim do jornalismo. Haverá sim, mais colaboração de quem participa dos acontecimentos. Mas isso não será o fim, só uma mudança".

o que é jornalismo colaborativo em seu ponto de vista?

O jornalismo colaborativo é constituído pelo interesse de pessoas sem formação profissional em comunicação em transmitir informações que elas acreditam ser relevantes para o público. Canais como o VC Repórter dão vazão a isso.

Acredito que a Internet impulsionou o jornalismo cidadão ou colaborativo, pois, no momento em que essas pessoas passaram a veicular notícias em blogs pessoais ou sites de relacionamento, a notícia deixou de ser monopólio de veículos de comunicação. 
Qual é a área editorial (cidades, cultura, economia) com maior apelo para produção de conteúdo por parte dos internautas de seu serviço de jornalismo colaborativo? Por quê?

A maioria são notícias do cotidiano, fatos que afetam diretamente o leitor. São fatos fáceis de serem distinguidos como notícia: acidentes de trânsito, buracos e problemas em ruas ou estradas, alagamentos e árvores caídas são bem frequentes. Fatos relacionados a chuvas e demais fenômenos climáticos são sempre assunto. Manifestações também contam sempre com registros de colaboradores.

A editoria de Cidades é a mais utilizada, seguida pela de trânsito. No entanto, cada vez mais temos recebido um conteúdo de maior abrangência editorial. Temos muitos eventos culturais e esportivos, celebridades, pautas de comportamento e moda, novidades na Internet.

Há uma maior tendência no jornalismo colaborativo de seu portal a valorizar os acontecimentos da região onde vivem os autores das matérias? Qual a razão disso, em sua opinião?

Acho que aí está a origem e o sentido do jornalismo colaborativo. Não vejo como o jornalismo [colaborativo] pode não ser regionalista numa primeira fase. O internauta, na grande maioria das vezes, fala sobre o que acontece à sua volta, sobre o que lhe afeta diretamente e o seu entorno.

Ele pode falar da árvore que caiu na frente da casa dele, do buraco na rua do bairro, do problema de água na cidade. Em raros casos ele vai flagrar um acidente que acontece longe do seu trajeto cotidiano. Em uma segunda instância, que já conseguimos atingir aqui no VC Repórter, ele vai falar sobre um destino turístico que visitou, sobre o anúncio de uma banda, ou a morte de um esportista. Mas tudo ligado ao círculo de interesse dele. 
As pessoas, mesmo que escrevam sobre o Dr. Hollywood, falam sobre o que é caro e a elas. E não só fisicamente.

Já houve casos em que autores enviam reproduções de matérias de outros veículos? Como esse tipo de caso é tratado pela redação?

Sim, muitas vezes por desconhecer o conceito de direito autoral, o leitor envia matérias de algum jornal da região, fotos de amigos do Orkut, fotos copiadas de outros sites. Não utilizamos material de divulgação ou assessoria de imprensa, assim como textos e fotos publicados em outros veículos, agências de notícias e conteúdo profissional. Publicamos apenas material produzido pelos próprios leitores no canal. Esses casos são encaminhados para a editoria correspondente como sugestão de pauta desde que o leitor esteja de acordo.

Cada caso é analisado separadamente. Se a foto é produzida pelo leitor e o texto é copiado, apenas para envio de informações, publicamos uma nota feita por nós com a imagem. Sempre estendemos a apuração em pautas em que isso é possível. Mas a iniciativa poucas vezes parte do leitor.

E material de divulgação/press-releases? 0 jornalimo colaborativo é mais suscetível a esse tipo de conteúdo? Como a redação se previne?

Em parte a dúvida foi respondida na questão anterior. Não aceitamos material de divulgação/assessoria de imprensa, salvo para complementar informação enviada por leitores anteriormente. Claro que muitos assessores usam o canal como meio de contato com a redação, e é quando encaminhamos a mensagem para as outras editorias. 
Os releases só representam uma forma de "erro" no jornalismo colaborativo. Nas outras editorias, convencionou-se usar as sugestões de pauta das assessorias de uma forma ou outra. Por isso não sei se o termo "mais suscetível" é correto.

Não precisamos de grandes estratégias de prevenção porque geralmente este tipo de material vem especificado claramente. Quando não, é fácil notar pelo tipo de texto, qualidade de foto, ou com uma busca na rede. Ou seja, a apuração que é feita com todas as notas acaba por esclarecer a origem da pauta. Desde que cheguei ao VC Repórter, apenas uma assessora negou que o material se tratava de um release. Mesmo assim, achamos o mesmo texto em outro veículo e não publicamos.

Os maiores riscos são representados pelas ações de marketing viral. Uma vez recebemos material de um publicitário e percebemos a intenção. Em outro momento, dois leitores nos mandaram material de outra ação como notícia —essa, sim, foi um erro.

\section{Como aconteceu?}

Foi uma sexta-feira, correria. Estávamos sob pressão e falhamos na apuração. Era o caso de um fusca cortado ao meio que estava sendo rifado. Dois leitores legítimos enviaram como verdade. Eles filmaram e acreditaram. Percebemos claramente quando tentam plantar informações. Mas foram leitores que nos enviaram material. Veja, não erramos porque somos um site colaborativo: erramos por falha de apuração. Está aí o caso clássico do "boimate" para provar que erros também acontecem no jornalismo tradicional. Não acho que o jornalismo colaborativo seja mais frágil, este controle precisa

ser feito. É óbvio que vai haver erros. E por isso que há editores. Sempre digo à equipe que não há matéria de uma fonte. Como no caso em que o trem atrasou —como posso confiar na pessoa que liga para a redação e diz que o trem levou $4 \mathrm{~h}$ para chegar? Ele pode estar querendo justificar um atraso no trabalho com uma notícia nossa. 
Os internautas que participam do serviço de jornalismo colaborativo de seu portal apuram informações antes de as submeterem? Que métodos usam (entrevistas, pesquisa, registro fotográfico/taquigráfico)? Como a redação "confia" nos seus colaboradores?

Sim, mas não são todos. Eles colhem informações no local por observação, com os envolvidos, com fontes oficiais. Alguns deles até mesmo nos sugerem telefones das fontes com quem a matéria pode ser checada. No entanto, não usamos apenas essas fontes. Todo o material é checado antes de ser publicado, invariavelmente. A apuração parte das informações do leitor. Portanto, ele funciona realmente como um pauteiro/repórter. As entrevistas são utilizadas apenas quando conseguimos checar a declaração obtida pelo leitor.

Como a redação trabalha com o material recebido de internautas? Existe checagem das informações? É feita algum tipo de apuração adicional/ enriquecimento dos dados?

Sim. Como dito acima, todas as informações são checadas e novos dados são adicionados para compor a matéria. Na maioria dos casos, o texto é feito ou enriquecido pelos nossos redatores, pois raras vezes eles chegam de acordo com as normas editoriais do portal para publicação.

o mero flagrante de um acidente, uma chuva forte ou registro de um show pode ser considerado jornalismo colaborativo? Como a redação trabalha com esse tipo de material? 
Sim, como você pode ver, todos os exemplos citados são publicados no site. O leitor ajuda na composição do noticiário do portal, podendo ser essa colaboração parcial, com apenas uma foto, ou integral, com uma notícia completa.

"Se o leitor achou que o material enviado é uma notícia, é o nosso papel entender o motivo e, de preferência, garantir espaço para aquele conteúdo", diz o manual do portal.

E o registro pessoal sobre uma obra de arte, um carro ou situação vivida pelo internauta? Textos em primeira pessoa são considerados para o noticiário colaborativo? Por quê?

Depende do tipo de texto. Artigos ainda não possuem espaço no VC Repórter, mas há a possibilidade de que essa divisão venha a existir. O leitor ainda confunde um texto opinativo com notícia, principalmente em casos políticos. Relatos de uma viagem, por exemplo, são publicados e com grande proveito. Um grande exemplo de jornalismo colaborativo nesta linha é o guia de turismo Zagat (www.zagat.com).

Você considera o internauta que participa de seu serviço de jornalismo realmente um cidadão-repórter? Ou ele teria uma função, hoje, mais semelhante à de uma fonte de informação?

Acredito que ele se encontra em uma fase intermediária. Ele não é apenas uma fonte, porque ele não é só a referência sobre determinado assunto, é também o principal interessado em ver outros lados. Nem é apenas um repórter, porque a matéria não pode ser construída com base no seu ponto de vista. Um repórter contratado para um meio de comunicação conta total credibilidade da empresa em seu relato. No caso do jornalismo colaborativo, não sei se um dia isso será possível. Como disse, todas as notícias partem, de um jeito ou outro, de interesses pessoais. 
Como uma vez me disse Edson Rossi, nosso diretor de conteúdo, o cidadão-repórter transforma a função do jornalista. E eu acredito e concordo com isso. Se eles são os pauteiros/repórteres, cabe a nós sermos editores.

\section{Qual é a evolução desta fase intermediária?}

Acredito que ela exige uma mudança não só no jornalismo colaborativo, mas na educação em geral, na consciência social, política e até jurídica das pessoas, até para que elas saibam o que pode acontecer se elas publicarem uma notícia falsa. Há um colaborador de Blumenal que passa até o número de telefone da fonte. Mas ele publica no blog e manda para o G1. Como eles não mexem no texto, eles publicam primeiro. Mas se a gente não dá primeiro, tem que dar melhor. É por isso que checamos com outras fontes, colocamos mais informação. Para que você quer uma nação inteira de jornalistas? É utópico. É o fim do jornalismo. Haverá sim, mais colaboração de quem participa dos acontecimentos. Mas isso não será o fim, só uma mudança.

Você acredita que a criação de perfis e a utilização de sistemas de pontos que criassem um ranking de colaboradores ajudaria os leitores do serviço de jornalismo colaborativo de seu portal a identificar que autores são melhores e mais confiáveis?

Já vi isso em outros sites, mas não sei como funciona o sistema de apuração e publicação deles. No nosso caso, não seria algo eficiente, pois, a partir do momento em que todas as matérias são apuradas e checadas pela redação, esse sistema mediria apenas a freqüência com que cada leitor colabora. Se houvesse maior ou menor credibilidade em cada matéria, ela deveria ser atribuída a nós, da redação. 
o jornalismo colaborativo de seu portal tem a mesma credibilidade que o noticiário profissional? 0 que diferencia os dois, em seu ponto de vista?

Acredito que sim, e trabalhamos para isso. Tanto que as matérias do VC Repórter disputam espaço na capa com as matérias produzidas pela equipe regular de cada editoria. Os critérios são os mesmos para avaliar todas as matérias.

A diferença é que, algumas vezes, estamos em desvantagem em relação à qualidade de fotos, por exemplo. Em outros casos, temos a vantagem da exclusividade.

Por que redes sociais como Orkut ou MSN são tão populares no Brasil, mas o jornalismo colaborativo nem tanto? 0 jornalismo colaborativo está dando certo no Brasil? Por quê?

Em primeiro lugar, porque as redes sociais têm finalidade diferente do jornalismo colaborativo. Em segundo, acredito que muito se deve ao fato de que os brasileiros ainda não estão familiarizados com o conceito do jornalismo colaborativo -e também de jornalismo, principalmente na Internet. Aos poucos, eles estão descobrindo que a foto postada no Orkut e que fez tanto sucesso porque mostra o dia-a-dia de quem sofreu com uma cheia, por exemplo, pode virar (e é) uma notícia. Ou que o problema que atinge o bairro, e que vira tema de debate em uma comunidade, pode ser cobrado das autoridades por uma matéria de denúncia.

Talvez também, pela popularização das redes sociais, em que tudo pode ser publicado sem mediação, elas ainda não saibam definir o que é notícia de uma informação pessoal. Por exemplo, a foto de um animal de estimação, ou uma foto de alguém abraçado a uma celebridade. Apesar disso, acredito que, pelo grande interesse dos brasileiros em novas tecnologias e interação, o jornalismo colaborativo deve crescer. 
Mas o que ocorre ainda no jornalismo colaborativo, pelo menos no VC Repórter, é que ainda há um pouco de confusão com assistencialismo. E, a partir daí, pessoas passam a escrever pedindo coisas, como para participar de um programa de TV, ou ajuda para algum problema pessoal. Às vezes parece a Porta da Esperança. Há uma leitora que escreve uma vez por semana pelo menos dizendo que quer participar do Big Brother. "Tenho um pai doente". "Preciso receber do INSS". "Comprei algo pela Internet e não recebi". Confundem o site com o serviço de consumidor da Folha. "Minha filha não é bonita? Ela tinha que ser modelo". A gente indicou agência... 
RODRIGO FLORES Jornalista, gerente geral de noticias do UOL

A participação do internauta na construção do noticiário dos grandes portais está muito mais ligada à etapa da pauta que à apuração ou à edição do material jornalístico. Na visão do jornalista Rodrigo Flores, do UOL, ao enviar material para a redação o público complementa o trabalho do jornalista, que então deve prezar pelos processos que conferem à informação características que a tornam notícia. "Embora o UOL não tenha canais abertos específicos para pautas, as pessoas usam todos os canais possíveis para nos pautar. E já fizemos inúmeras matérias com base nesse tipo de contato do público", diz. Flores estava no UOL quando houve a publicação, na capa do portal, de uma foto falsa sobre o acidente com o avião da TAM em Congonhas (SP) em julho de 2007. Segundo ele, é muito difícil para um grande portal adotar a colaboração com os filtros necessários para evitar fraudes. "O risco da mentira está presente a todo momento. A partir do momento em que você registra uma entrevista de alguém, você corre esse risco. (...) O desafio do jornalismo é tentar chegar perto do risco zero."

o que é jornalismo colaborativo em seu ponto de vista?

Existe uma cadeia de produção da notícia, que começa na pauta, na reportagem, na redação - se é que estamos falando de um texto, porque se for um vídeo ou foto não há redação- e edição, até a publicação. Pensando rapidamente, o jornalismo colaborativo é aquele em que a reportagem/redação utiliza, em vez de profissionais da área, jornalistas de uma redação, o próprio público. Caberia aí então à redação, para que se enquadre no 
campo jornalístico, a possibilidade de pautar ou não o trabalho do público, além do trabalho de edição. Porque pode existir um serviço de jornalismo colaborativo sem edição, mas não tenho certeza do modelo. A mera informação pode ser colaborativa, com certeza, mas não necessariamente ela será jornalismo.

As notícias que estampam a home page de seu portal seriam muito diferentes sem o jornalismo colaborativo? Por que?

No mínimo, o conteúdo do público complementa o nosso trabalho. Em alguns casos, ele é o nosso trabalho, é fundamental. Porque às vezes é o único recurso. Um exemplo foi o desabamento da ponte em Agudos (RS). Não temos repórter lá. A única forma de conseguir rapidamente registros do local seria acionar o público. Outro exemplo? São Luiz do Paraitinga. A cidade foi devastada. Fizemos um "antes-e-depois" [álbum com fotos dos locais antes e depois da enchente que ocorreu em 2009], pedimos ajuda aos internautas. As pessoas publicam fotos no UOL Mais, fazemos um filtro do que chega, e as imagens mais legais publicamos no template de notícias, identificadas com uma marca d'água. Muitas vezes a gente mistura conteúdo do público e conteúdo do UOL.

E material de divulgação/press-releases? 0 jornalimo colaborativo é mais suscetível a esse tipo de conteúdo? Como a redação se previne?

Acho que as assessorias estão muito mais preparadas para convencer os jornalistas a publicarem conteúdo do que a encontrar brechas no jornalismo colaborativo. Essa questão talvez seja menos importante, porque o press release hoje é um grande problema para o jornalismo —não existe neste caso o jornalismo, mas só a divulgação.

Em relação à fraude, estamos mais maduros sim, e mais preparados, mas não imunes. Poderia sim voltar a acontecer. Se você se dispõe a adotar este recurso de colaboração 
em um portal do tamanho do UOL, é muito difícil estabelecer os filtros necessários para evitar uma fraude. O risco da mentira está presente a todo momento. A partir do momento em que você registra uma entrevista de alguém, você corre esse risco. "Eu vi o avião cair", mas não viu. O desafio do jornalismo é tentar chegar perto do risco zero.

Como a redação trabalha com o material recebido de internautas? Existe checagem das informações? É feita algum tipo de apuração adicional/ enriquecimento dos dados?

Se necessário [há apuração adicional]. Mas há casos em que nosso trabalho é muito facilitado. Por exemplo, em São Luiz do Paraitinga: a cidade estava toda devastada; como o cidadão forja uma devastamento? Tivemos um caso de foto indevida, circulada na ocasião do apagão [que atingiu diversos Estados do Sudeste e Sul do país, também em 2009]. Era uma foto escurecida, mas que não foi tirada no dia do apagão. Da mesma forma que contamos com a ajuda do público para enviar o conteúdo, contamos também com ajuda para moderar o conteúdo —via "Comunicar erros", um internauta nos alertou. Com esse indício, resolvemos tirar do ar. Tudo indicava que todas as fotos eram do apagão, pela abrangência da foto, mas o que houve foi uma depuração, uma correção com base na ajuda do público. Não há pós-edição neste caso, da mesma forma que se eu, jornalista, errei em uma legenda em um álbum criado pela redação, eu vou lá e corrijo.

o mero flagrante de um acidente, uma chuva forte ou registro de um show pode ser considerado jornalismo colaborativo? Como a redação trabalha com esse tipo de material?

Tendo a achar que não, porque acredito que o jornalismo envolve pauta, reportagem e edição. O flagrante é uma parte do jornalismo, é fundamental, ajuda muito, mas não sei se ele é jornalismo por não compreender todo o processo que define o jornalismo -isso 
justificaria a presença de uma moderação. Se você criar um site do seu bairro, até pode ser que você exista sem moderação. No nível de um grande portal como o UOL, isso seria impossível sem moderação.

O jornalismo colaborativo está muito ligado ao processo de pauta. Embora o UOL não tenha canais abertos específicos para pautas, as pessoas usam todos os canais possíveis para nos pautar. E já fizemos inúmeras matérias com base nesse tipo de contato do público. Sem a pauta, a sugestão do público, o jornalismo fica muito mais difícil. A reportagem é a execução. A edição ainda fica por conta de nós jornalistas.

Você considera o internauta que participa de seu serviço de jornalismo realmente um cidadão-repórter? Ou ele teria uma função, hoje, mais semelhante à de uma fonte de informação?

De novo caímos numa questão semântica: se ele é um cidadão-repórter, ou é um cidadão-cidadão, mandando um flagrante para tornar público o que ele viu. A gente também não pode transferir para o público essa responsabilidade completa da reportagem. Ele contribui para a reportagem, ele não é o repórter. Se você quiser chamálo de repórter eu também não me ofendo, porque volta e meia existe essa discussão.

Acho que o jornalismo muito dificilmente é feito sem a participação do público, mesmo passivamente. O que muda é que o cidadão passa a ser mais ativo diante deste processo. Também me sinto um pouco incomodado de não considerar o cidadão que contribui em casos como o que fizemos [durante as enchentes] em Santa Catarina, em que as pessoas mandaram fotos da tragédia e seis meses depois pedimos para elas retornarem ao local das fotos e mandarem as fotos dos lugares. Poxa, o internauta fez o trabalho todo, ele fez a reportagem para nós. Muito dessa discussão carrega o preconceito de que fotojornalismo não é jornalismo. Mas isso é bobagem. 
Mas posso chamá-lo de fonte? Difícil. Em alguns casos sim, mas em outros ele é coautor. Isso depende do grau de participação. Quando ele contribui com um depoimento, ele é fonte, ele conta o que aconteceu. Mas quando ele vai até um local pautado por nós e produz uma foto, ele é co-autor. No caso de Santa Catarina, a pauta foi nossa, ele fez a reportagem e nós editamos —colocamos numa casca, pusemos uma legenda e publicamos.

o jornalismo colaborativo de seu portal tem a mesma credibilidade que o noticiário profissional? 0 que diferencia os dois, em seu ponto de vista?

Varia muito. Depende da maneira como decidimos apresentar, que não é homogênea; depende do destaque, porque publicar na home de UOL Notícias é uma coisa, na home do UOL é outra. Então o internauta pode publicar em nossa plataforma de vídeos, que é aberta, e a partir deste momento isso está no UOL. Mas se usamos este conteúdo dentro de nossa matéria, é outra coisa. Podemos pegar uma foto do internauta e colocá-la na home page. $\mathrm{O}$ internauta do UOL espera credibilidade do UOL. Por isso depende do quanto de destaque e da forma de apresentação — dentro de um álbum de Notícias ou na plataforma aberta para os usuários, o UOL Mais.

Por que redes sociais como Orkut ou MSN são tão populares no Brasil, mas o jornalismo colaborativo nem tanto? 0 jornalismo colaborativo está dando certo no Brasil? Por quê?

Temos usado o jornalismo colaborativo no UOL, o Jornal Nacional todo dia tem exibido alguma coisa do público. Então depende do modelo que você considera para dizer que está dando certo ou não. No meu entendimento o fenômeno é crescente, e temos que usar cada vez mais. Mas não creio que vamos usar [na grande imprensa] modelos 
muito puros, que acreditam exclusivamente na auto-regulação. Mas o que vejo é que as redes sociais têm uma finalidade completamente diferente, não sei se cabe comparação. O Orkut, o MSN são maneiras de interação social. O jornalismo, pelo menos como está na cabeça das pessoas, é bem pouco interativo. É uma forma de comunicação social. As redes são muito mais interessantes para o público porque promovem interação social, para conversar, conhecer pessoas. A diferença está no princípio, isso muda tudo. As coisas nascem tendo como base a comunicação, mas cada uma para um lado. 
A colaboração sempre fez parte do trabalho jornalístico -e o público sempre teve espaço na imprensa, fosse como personagem de notícias ou comentarista ativo. Esta é a visão de Márion Strecker, diretora de conteúdo do UOL, que enxerga o trabalho de checagem de informações externas tão ou mais caro que a contratação de jornalistas para a apuração e a construção de reportagens. "(...) Sempre tive uma sensação ruim com esse desejo expresso por algumas forças do mercado em se fazer jornalismo ou de se ganhar dinheiro com jornalismo sem jornalistas", diz Strecker, para quem o jornalismo colaborativo pode ser uma forma de baratear custos de produção da mídia. Mesmo assim, ela acredita que o movimento não ganhou força no Brasil pela falta consciência e de cobrança, motores de uma atividade essencialmente crítica como o jornalismo.

\section{0 que é jornalismo colaborativo em seu ponto de vista?}

O público sempre participa e sempre participou em alguma medida do noticiário. Os jornais, esse veículo do século 19, sempre tiveram em certa medida a colaboração do leitor, expressa em seção de cartas, em críticas para ombudsman, repórteres sempre foram às ruas e tiveram contato direto com o público e aprenderam alguma coisa com isso. O público sempre enviou correspondências, antes por carta, agora por e-mail... fax, documentos, denúncias. Colaboração faz parte da natureza do trabalho jornalístico. Por isso esse termo jornalismo colaborativo sempre pareceu um pouco bizarro. 
As notícias que estampam a home page de seu portal seriam muito diferentes sem o jornalismo colaborativo? Por que?

Entre ter o público como personagem e tê-lo como autor, há um amplo espectro de atividades, que podem e são exploradas. Por exemplo, você pode ter uma repórter do UOL, a Daniela Paixão, saindo com um cinegrafista e ouvindo pessoas na rua. Ou você pode ter depoimentos de pessoas, feitos em vídeo, elas mesmo se filmando, enviadas espontaneamente ou por estímulo do portal. Isso tudo o UOL utiliza cotidianamente. Estou dando alguns exemplos bem clássicos, só para explicar que, na minha visão, não existe uma linha divisória muito definida entre o jornalismo colaborativo e o não colaborativo, porque a gente vive em sociedade, e o nosso jornalismo trata de questões sociais, ele é feito para a sociedade e sobre a sociedade. O jornalismo não-colaborativo seria o quê? O jornalismo ditatorial, imperial, divino?

o jornalismo colaborativo dá ou pode dar certo em grandes portais de conteúdo? Ou é um fenômeno que ficará relegado a sites independentes? Por quê?

Essa questão me arrepia, criar um veículo em que jornalistas não fazem jornalismo, mas apenas recebem e rechecam material externo, enviado por pessoas não treinadas, sem capacitação para isso —o custo de um jornalista checar devidamente um texto externo pode ser tão alto ou maior do que o custo de produzir um texto original, uma reportagem original. Claro que depende do grau de ambição de qualidade desse veículo —quanto mais alta a ambição, mais alto o custo de produção. Então se o assunto é só o buraco de rua, tudo bem. Mas se o assunto é investigar um crime de colarinho branco, para citar dois extremos, a coisa se complica. 
Por que redes sociais como Orkut ou MSN são tão populares no Brasil, mas o jornalismo colaborativo nem tanto?

Rede social não tem nada a ver como jornalismo; pode-se até falar de notícias ali, mas é vida social. Jornalismo é uma pequeníssima parte da vida social das pessoas, sempre foi. Isso não é uma novidade. Você não pode comprar a leitura de um jornal com conversas de bar.

Isso não significa que desvalorizo a participação do público na Internet. Há coisas que acho de uma eficácia impressionante. Nos EUA, por exemplo, não vivo sem o Yelp colaboro sempre, escrevo. Os exemplos que mais admiro no momento estão mais ligados a serviços. Adoro as resenhas e as coações que as pessoas dão na App Store, da Apple. Comentários em notícias, muito eventualmente leio comentários relevantes — quanto mais complicadas as notícias, mais fácil encontrar comentários relevantes. A notícia tende a atrair menos gente, porque é um assunto mais árduo, e o comentário que esse tipo de texto normalmente atrai é mais refinado.

Redes sociais são um ambiente interessantíssimo para os jornalistas se relacionarem com o público e suas fontes. Para pauta e feedback.

o jornalismo colaborativo de seu veículo pode ser comparado ao exercido por sites como o OhMyNews (Coréia do Sul) ou o iReport (EUA)? Seu portal se inspirou em serviços como estes para criar seu modelo de jornalismo colaborativo?

Continuo irritada com a expressão de jornalismo colaborativo, como se só o OhMyNewws fosse colaborativo. 
o jornalismo colaborativo é uma forma de baratear a produção de conteúdo jornalístico? Por quê?

Meu "desconfiômetro" sempre me mandou os seguintes alertas: verifique se isso não é uma maneira de baratear custos e nada mais, que vai ter como consequência possível uma piora da qualidade do produto oferecido; veja se esse não é um movimento arrivista; suspeite do risco de determinadas forças do mercado ou de determinados agentes sociais a quem interesse ferir de morte o bom jornalismo. Quem não conhece ou não valoriza o bom jornalismo acha quimérica a possibilidade de fazer jornalismo sem jornalistas. Afinal não é o que o Google tanta fazer com o Google News? Por que é que nós vamos contratar jornalistas? Será que o Google pensa nos objetivos ou por quem os veículos que ele exibe estão sendo guiados? Então eu sempre tive uma sensação ruim com esse desejo expresso por algumas forças do mercado em se fazer jornalismo ou de se ganhar dinheiro com jornalismo sem jornalistas.

Mas o jornalismo colaborativo não democratiza a atividade jornalística ao trazer ao público vozes que não fazem parte da mídia?

Trabalhei por 12 anos na Folha, e a Folha sempre recebeu a colaboração de nãojornalistas. É um jornal inclusive que contrata especialistas como jornalistas, e transformou especialistas em jornalistas, ao não exigir a obrigatoriedade do diploma para que escrevam num jornal. Portanto incluir especialistas no fazer jornalístico é algo elementar, que eu pessoalmente aprendi nos meus anos de escola Folha, e de alguma forma prosseguimos no UOL quando convidamos especialistas para o UOL, seja em entrevistas ou abrigando aqui sites desses especialistas. 
o problema então é a credibilidade? 0 conteúdo colaborativo não pode ser confiável?

Sim, claro que pode ser confiável. Entre os elementos essenciais está a identificação do autor, isso é básico. Todos os sistemas que identificam a sério a autoria, como a Apple Store faz, por exemplo, porque você precisa ser cliente, ter seu cartão de crédito no sistema, além de seu endereço residencial, porque dá garantia dos produtos que você compra, há um histórico, enfim, quando você sai do anonimato, normalmente o nível da conversa sobe bastante. O anonimato é mortal, infelizmente. No mundo ideal o anonimato deveria ser permitido, mas ele não existe. Outra questão é a durabilidade da relação com a pessoa com aquele meio, com aquele site. Quanto mais tempo, mais rico é o comportamento da pessoa naquele ambiente, e mais confiável é o que ela escreve.

o jornalismo colaborativo pode substituir, hoje ou futuramente, o jornalismo tradicional? Por quê?

O problema no Brasil é a falta de consciência de cidadania. Acho que essa é a razão de o jornalismo colaborativo não dar certo por aqui. O cidadão raras vezes se sente dono da sua cidade, tem a consciência do quanto imposto ele paga, e do quanto ele pode cobrar dos nossos governantes. Ninguém lembra em quem votou para deputado, para prefeito na última eleição. A atividade política é baixa, associações de bairros são poucas. O engajamento social é alto, mas o político é muito baixo. Se o voto não fosse obrigatório no Brasil, a quantidade de pessoas que votam cairia drasticamente. As pessoas não leem os programas, não vão às convenções, pedem santinho para colar voto no dia da eleição porque o voto é obrigatório. Então falta consciência dos próprios direitos, falta cobrança, com isso falta motivo para exercer uma atividade jornalística que deve ser essencialmente crítica. Porque se não é crítica, não é jornalismo, é propaganda. 
Para o jornalista Caíque Severo, o jornalismo colaborativo é a cauda longa da informação na Internet. O grau de participação entre os usuários vai desde um fato que interessa unicamente a outra pessoa na rede - como o nascimento de um parente ou a própria foto em um espelho- às notícias mais amplas, em uma escala semelhante à proposta por Chris Anderson quando cunhou o termo. Quanto mais complexa a participação, menos atores. E daí uma possível justificativa para a grande popularidade das redes sociais em relação à prática do jornalismo colaborativo, e também a maior participação de usuários como fontes de informação do que como cidadãos-repórteres.

Severo também não vê o jornalismo colaborativo como ameaça ao jornalismo tradicional. Ele seria apenas mais um modo de participação do público, prática comum ao noticiário online, além uma espécie adicional de filtro de informação que não substitui o trabalho do jornalista: "O que determinado veículo selecionou para ir para a capa continua sendo um critério importantíssimo de priorização".

\section{0 que é jornalismo colaborativo em seu ponto de vista?}

Na Internet, usamos este termo para descrever iniciativas que utilizam a participação dos cidadãos na coleta de informações, envio de fotos, notícias etc. O grau de participação e moderação dos veículos ou sites organizadores desse conteúdo varia. Alguns publicam somente o que é checado pela equipe do veículo, outros publicam tudo que é enviado pelas pessoas. 
As notícias que estampam a home page de seu portal seriam muito diferentes sem o jornalismo colaborativo? Por que?

Acho que a decisão se as notícias vão ou não para a home page do portal passa por outro critério. Não importa se foram enviadas pelos usuários ou não. Se é notícia e é relevante, pode ganhar destaque, inclusive na home page. De novo, o critério de moderação e destaque varia entre cada veículo.

Por que redes sociais como Orkut ou MSN são tão populares no Brasil, mas o jornalismo colaborativo nem tanto?

Acho que uma coisa não tem nada a ver com a outra. Existem vários níveis de participação do usuário. Redes sociais oferecem no mínimo o nível mais básico de participação, que é simplesmente estar na rede. Você vai lá e cria o seu "perfil". Naturalmente vai existir muito mais gente que simplesmente criou um perfil em uma rede social do que aqueles que têm a capacidade e disposição de produzir qualquer conteúdo. É uma escadinha. Quanto mais complexa a participação, menos atores. Compare o fenômeno fotolog no Brasil de alguns anos atrás. Ele ocorreu quase simultaneamente ao surgimento dos blogs, mas tínhamos muito mais gente com um fotolog do que com um blog. É muito mais fácil criar um fotolog e publicar fotos do que ter um blog e atualizá-lo. Eu costumo brincar que para ter um blog você precisa ter o que dizer. No fotolog, não. Basta tirar uma foto sua no espelho. Também não sei dizer se o jornalismo colaborativo é menos bem sucedido no Brasil do que em outros países. Gostaria de ver os números percentuais. 
Você considera o internauta que participa de seu serviço de jornalismo realmente um cidadão-repórter? Ou ele teria uma função, hoje, mais semelhante à de uma fonte de informação?

Eu acho que isso varia muito com a definição de jornalismo que cada um dá a sua iniciativa. Você pode dizer que apenas as notícias que realmente são relevantes a todas as pessoas serão consideradas relevantes. Ou você pode assumir que notícia é o que cada pessoa acha importante. Por exemplo, para um usuário notícia pode ser o nascimento de alguém de sua família. Imagine isso como a cauda longa ao extremo da produção de notícias. Isso não precisa ter nenhuma relação com o consumo ou audiência de cada notícia. O bonito da Internet é que você pode ter uma informação produzida por uma pessoa que só interessa a outra uma pessoa. O tratamento que cada veículo dá a sua iniciativa também ajuda a definir se a colaboração vai ser usada como fonte de informação ou notícia pronta. Nessa decisão deve pesar uma avaliação de quantos participantes o veículo deseja ter. É natural que existam muito menos cidadãos-reporteres do que cidadãos participando como fonte de informação.

o jornalismo colaborativo de seu veículo pode ser comparado ao exercido por sites como o OhMyNews (Coréia do Sul) ou o iReport (EUA)? Seu portal se inspirou em serviços como estes para criar seu modelo de jornalismo colaborativo?

Não estou autorizado a falar em nome do iG, portanto prefiro não comentar sobre o nosso produto. 
o jornalismo colaborativo dá ou pode dar certo em grandes portais de conteúdo? Ou é um fenômeno que ficará relegado a sites independentes? Por quê?

Acho que não há mais como não utilizar ferramentas de colaboração na construção do produto jornalístico. Mesmo que o veículo não tenha uma funcionalidade específica, os usuários enviam material voluntariamente. O conceito de "dar certo" também é variável. Muitos podem ter como critério a quantidade de itens enviados pelos usuários e isso pode acabar modificando como o produto funciona, facilitando ao máximo a participação. Outras iniciativas podem focar na qualidade, velocidade e exclusividade da informação. Nesses casos, provavelmente o veículo vai querer reduzir a quantidade de participantes para poder focar naqueles que realmente têm algo para contribuir.

o jornalismo colaborativo é uma forma de baratear a produção de conteúdo jornalístico? Por quê?

Não tem nada a ver com custos. Se você quer fazer jornalismo de qualidade precisa investir recursos compatíveis no trabalho de checagem, apuração e moderação. Qualidade é resultado dos recursos investidos.

Não será mais difícil às pessoas, em um contexto de excesso de informação, lidar com mais e mais conteúdo em um contexto de construção coletiva de material? o jornalismo colaborativo não será, portanto, mais "difícil" que o jornalismo tradicional?

É por isso que a cada dia surgem novas formas de filtrar a informação. A mais recente delas é o filtro social. Através das redes sociais eu acabo chegando à informação que é mais relevante. É claro que esse é só um dos filtros que a pessoa vai usar. Dependendo do perfil da pessoa ela vai continuar querendo dar uma olhada nas páginas iniciais dos 
sites de informação ou mesmo na primeira página dos jornais impressos. O que determinado veículo selecionou para ir para a capa continua sendo um critério importantíssimo de priorização.

o jornalismo colaborativo pode substituir, hoje ou futuramente, o jornalismo tradicional? Por quê?

Jornalismo é jornalismo. Não existe uma disputa entre tipos de jornalismo. Ou uma coisa é notícia ou não é. E o critério do que é notícia tem vários níveis e cada leitor escolhe os filtros que deseja usar para chegar ao que ele considera notícia. 
RONALDO LEMOS Doutor em Direito Civil, fundador do site colaborativo Overmundo

Apesar de o jornalismo colaborativo no Brasil ser muito mais difuso e desagregado que em países como os EUA, o fenômeno já mostrou ser um importante canal de informação em casos como o do terremoto em São Paulo, em 2009 -e demostra a rica combinação de mídias e mensagens que a Internet oferece. Esta é a visão do doutor em Direito Civil e ativista da Internet Ronaldo Lemos, criador do site colaborativo Overmundo, um dos primeiros a trazer ao país, especificamente para a área cultural, ferramentas de produção colaborativa de conteúdo jornalístico. Lemos acredita que a colaboração não substituirá o jornalismo tradicional, mas o transformará —para justificar a convivência, ele cita processos como o do jornalismo investigativo, por exemplo, extremamente caro e visto como "bem público".

o que é jornalismo colaborativo em seu ponto de vista?

Jornalismo colaborativo é uma consequência da natureza de mão dupla da Internet, em que qualquer pessoa pode não só receber informação, mas também disseminá-la. Não existe uma atividade única que possa ser definida como jornalismo colaborativo, há um conjunto de atividades e mídias em que ele acontece, das redes sociais, passando pelos blogs e pelo Twitter. 
Por que redes sociais como Orkut ou MSN são tão populares no Brasil, mas o jornalismo colaborativo nem tanto?

Essa é uma questão interessante. Nos EUA houve um amadurecimento muito rápido da blogosfera, que passou a se organizar e competir com os veículos de mídia tradicional, disputando inclusive verba publicitária. Isso não aconteceu do mesmo jeito no Brasil. Mas não quer dizer que não existe jornalismo colaborativo por aqui. O que aconteceu nos EUA é que a blogosfera passou de certo modo a espelhar o modelo jornalístico da mídia tradicional. Isso fez com que ficasse mais fácil identificar a atividade como "jornalismo". No Brasil, o jornalismo colaborativo é muito mais difuso e desagregado. Mas ele também acontece, como mostrou o papel do Twitter no apagão do ano passado (2009).

Há uma maior tendência no jornalismo colaborativo a valorizar os acontecimentos da região onde vivem os autores das matérias? Qual a razão disso, em sua opinião?

No Brasil, a razão é o caráter eventual da prática do jornalismo colaborativo. Ele muitas vezes depende da oportunidade, do fato de alguém conectado à rede presenciar um determinado fato na sua comunidade local. Isso se deve também à falta de recursos, já que no Brasil ainda é raro ver um site colaborativo com correspondentes espalhados pelo país (com notórias exceções, como o caso do Overmundo, site que participei da criação). 
Você considera o internauta que participa de seu serviço de jornalismo no Overmundo realmente um cidadão-repórter? Ou ele teria uma função, hoje, mais semelhante à de uma fonte de informação? Por quê?

Há as duas coisas. Há relatos pessoais, totalmente individualizados, verdadeiros tesmunhos no Overmundo. E há jornalistas mesmo, graduados ou graduandos, que usam o site para fazer jornalismo propriamente dito. O que acho mais interessante é que isso é produto das diferentes motivações que levam as pessoas a participarem do site. Alguns querem dar visibilidade a uma atividade local, outros querem mesmo criar um relato objetivo, outros querem polemizar e assim por diante. No fundo, o resultado é uma combinação muito rica, que mostra que há muitas mídias e muitas mensagens diferentes dentro da Internet.

o Overmundo trabalha com moderação de conteúdo ou com jornalistas profissionais que editam o material recebido?

Não, o Overmundo tem uma moderação geral que cuida da pertinência temática dos conteúdos e faz valer os termos de uso do site. Mas não há edição dos materiais, essa edição acontece colaborativamente e de forma espontânea, através da interação de quem publica artigos com outros usuários do site. É comum ver contribuições aos textos ou mesmo sugestões de alteração por conta de erros de grafia etc. 
o jornalismo colaborativo do Overmundo pode ser comparado ao exercido por sites como o OhMyNews (Coréia do Sul) ou o iReport (EUA)? Seu portal se inspirou em serviços como estes para criar seu modelo de jornalismo colaborativo?

O Overmundo foi criado muito antes do iReport e pouco depois do OhMyNews. Quando fizemos os site, tivemos de inventar muita coisa original e acho que o site contribuiu para avançar os modelos de jornalismo. Não por acaso, gente como o Ethan Zuckerman, do Berkman Center de Harvard e fundador do projeto Global Voices, fez comentários muito positivos e entusiasmados sobre o site, como nesse texto aqui: http://www.worldchanging.com/archives/005382.html. Além disso, fizemos um texto na época da criação do site, explicitando todas as influências que levaram a ele, disponível aqui http://www.overmundo.com.br/estaticas/creditos.php. De lá para cá muita coisa mudou, mas é interessante ver as como as ideias se formaram.

o jornalismo colaborativo dá ou pode dar certo em grandes portais de conteúdo? ou é um fenômeno que ficará relegado a sites independentes, como o Overmundo? Por quê?

Acho que o futuro dos grandes portais de conteúdo é se integrar cada vez mais ao jornalismo colaborativo. Existe, principalmente no Brasil, uma lacuna muito grande em agregar a produção de jornalismo colaborativo espalhada pela rede. E acho que os grandes portais podem muito bem contribuir para desempenhar essa função. 
o jornalismo colaborativo seria então uma forma de baratear a produção de conteúdo jornalístico para os portais? Por quê?

Em alguns casos específicos sim. Uma das lições que aprendemos com o Overmundo é que a rede e a colaboração faz muito por você, mas não faz tudo. Será sempre necessário ter uma equipe de moderação, edição ou interação, por menor que ela seja. Aliás, o sucesso da maioria dos projetos colaborativos depende justamente disso.

Não será mais difícil às pessoas, em um contexto de excesso de informação, lidar com mais e mais conteúdo em um contexto de construção coletiva de material? o jornalismo colaborativo não será, portanto, mais "difícil" que o jornalismo tradicional?

Sem dúvidas, o que mais falta são melhores filtros e melhores forma de agregar o conteúdo. Mas uma vez que isso seja feito, sua utilidade cresce enormemente. A questão é que a mídia tradicional também sofre do mesmo problema do excesso de informação e também dependerá cada vez mais de filtros e agregadores.

o jornalismo colaborativo pode substituir, hoje ou futuramente, o jornalismo tradicional? Por quê?

Não acho que haverá substituição, mas sim transformação. Inevitavelmente o jornalismo colaborativo vai transformar o jornalismo tradicional. Mas cada vez mais há a percepção de que a ideia de jornalismo tradicional é um bem público, por questões que envolvem reputação e recursos. O jornalismo investigativo, por exemplo, é caríssimo de ser feito e não há como negar que ele tenha uma função importantíssima. Acho que o futuro se definirá no processo de equilíbrio, em que o jornalismo colaborativo amplia as fronteiras da ideia de jornalismo, mas há uma percepção de que ter partes centralizadas da prática de jornalismo também é importante. 